\title{
GEOLOGIA DO MACIÇO ULTRAMÁFICO DE SANTA FÉ, GOIÁS
}

\section{ALEDIR PAGANELLI BARBOUR}

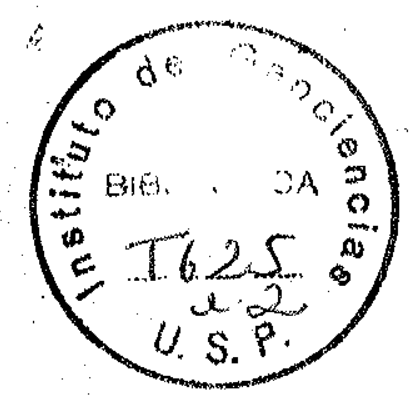

Tese apresentada em concurso para a obtenção

do Titulo de Livre Docente

Departamento de Geologia Econômica e Geofisica Aplicada

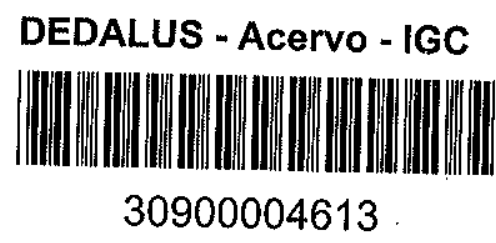

UNIVERSIDADE DE SÄO PAULO

INSTITUTO DE GEOCIÉNCIAS

$$
\begin{gathered}
\text { SĀO PAULO } \\
1976
\end{gathered}
$$


CAPITULO II

TRABALHOS ANTERIORES

CAPITULO III

METODOLOGIA

CAPITULO IV

LOCALIZAÇAO GEOGRÄFICA

CAPITULO V

RELEVO DO DISTRITO

CAPITULO VI

EVOLUÇAO MORFOLOGICA DO DISTRITO

CAPITULO VII

GEOLOGIA GERAL

VII.I - ROCHAS E SUA IDENTIFICAÇÃO

19

VII.I.1 - GNAISSES 


$\begin{array}{ll}\text { VII.1.2 - HORNBLENDA GNAISSE } & 22 \\ \text { VII.1.3 - IDENTIFICAÇAOO DOS DUNITOS, PERIDO } & \\ \text { TITOS EIROXENITOS NO CAMPO } & 24 \\ \text { VII.1.4- DUNITOS } & 29 \\ \text { VII.1.5 - PERIDOTITOS } & 30 \\ \text { VII.1.6 - PIROXENITOS } & 31 \\ \text { VII.1.7 - MISSOURITOS } & 33 \\ \text { VII.1.8 - MALIGNITOS } & 33 \\ \text { VII.1.9-SERPENTINITOS } & 35 \\ \text { VII.II-TRAÇOS ESTRUTURAIS } & 45\end{array}$

\section{CAPITULO VIII}

ALTERAÇÃO DAS ULTRAMĀFICAS

VIII.I - CONCREÇOES OOLITICAS - SOLO FERRALITICO MARROM

VIIT.II - CONCRECÕES PISOLITICAS - SOLO FERRALITICO MARROM

VIII.III-DISTRIBUIÇÃO DO $\mathrm{Ni}, \mathrm{Fe}, \mathrm{MgO}, \mathrm{Cr}$ e Co

CAPITULO IX

MINERAIS SINGENETICOS E EPIGENETICOS

IX.I - VERMICULITA

IX.II - GARNIERITA

IX.III- CALCEDÔNEA

IX.IV - MINERAIS OPACOS 
CAPITULO $X$

SUMARIO E CONCLUSOES

CAPITULO XI

AGRADECIMENTOS

CAPITULO XII

BI BL IOGRAF IA 


\section{INDICE DAS ILUSTRAÇOES}

\section{FIGURAS}

Figura 1 - Mapa de localização da ārea de Santa Fē . 8

Figura 2 - Esquema da evolução morfológica do distrito 15

Figura 3 - Mapa geológico do distrito de Santa $F \bar{e}$ anexo

Figura 4 - Mapa geológico e locação dos poços e furos de sondagem

anexo

Figura 5 - Perfil do furo de sondagem no2, 47+50 W, I em piroxenito e peridotito

Figura 6 - Perfil do furo de sondagem nois, N10+50 E7 em àrea de dunito e peridotito

Figura 7 - Anālise termo diferencial da ultramäfica serpentinizada

Figura 8 - Serpentinização de dunito de acordo com pro fundidade. Amostras coletadas no furo de sonda. $\mathrm{F}-27$

Figura 9 - Coluna esquemātica genērica - ultramäfica de Santa Fé, Goiās - ārea plana e baixa.

Figura 10 - Coluna esquemātica genērica - ultramāfica de Santa $F \bar{e}$ - ărea de topo e encostas ingremes das elevações

Figura 11 - Profundidade do nĩvel hidrostātico medida em zonas planas e rasas, a distāncias superiores a $300 \mathrm{~m}$ dos corrégos (nümero de medidas 121)

Figura 12 - Perfil dos poços e sondagem ao longo da $1 i-$ nha E6

Figura 13 - Perfil dos poços ao longo da linha E 10

Figura 14 - Profundidade do nivel hidrostātico e teores de $\mathrm{Ni}$ a distāncias variāveis dos córregos

Figura 15 - Variação da densidade com a profundidade em àreas de dunitos 
Figura 16 - Distribuição granulomētrica das concreções na zona topogräfica superficial

Figura 17 - Distribuição granulomētrica das concreções coletadas em segmentos verticais de trinta centimetros em solo ferralitico marrom

Figura 18 - Difratogramas de pō de raios $X$

Figura 19 - Distribuição do $\mathrm{Ni}$ e Co em äreas planas

Figura 20 - Distribuição do $N i$ em āreas de topo ou encosta de morro

Figura 21 - Distribuição do Fe em āreas planas

Figura 22 - Distribuição do Fe em äreas de topo ou encosta de morro

Figura 23 - Distribuição do Mgo em āreas planas

$\begin{aligned} \text { Figura } 24 \text { - } & \text { Distribuição do Mgo em ärea de topo ou en } \\ & \text { costa de morro }\end{aligned}$

Figura 25 - Distribuição do $\mathrm{Cr}$ em äreas planas Figura 26 - Distribuição do $\mathrm{Cr}$ em äreas de topo ou en
costa de morro

Figura 27 - Esquema das zonas de mineralização de ver miculita e opacos, em dunitos, peridotitos e piroxenitos

Figura 28 - Difratogramas de pö de raios $X$

\section{FOTOGRAFIAS}

Foto 1 - Vista geral do distrito, olhando para NNW.Zo na rasa e baixa central(dunito), circundada por morros arredondados de dunito. Ao fundo, no centro da foto, ciclo de aplainamento em arenitos com costão junto ao Morro Pontal (P). A $W$, região mais baixa e plana do vale do Araguaia 
Foto 2 - Vista do Vale do Araguaia para NW. Zona baixa, plana com o Morro do Pontal, que é um testemunho do nivel de erosão que atingiu tambëm a su perfície aplainada ao fundo, à direita, e que são rochas sedimentares e uitramáficas capeadas por uma crosta de calcedónea

Foto 3 - Gnaisse milonitizado com textura em moldura. Massa constituîda de quartzo e feldspato. Aumento $20 \mathrm{X}$; Nícöis semi-cruzados

Foto 4 - Furo 8 - Profundidade de $36 \mathrm{~m}$. Hornblenda gna is se com sinais de cataclase. Massa fragmentada de quartzo e feldspato. Porfiroblasto de hornblenda. Nícōis cruzados. Aumento $20 \mathrm{X}$

Foto 5 - Solo ferralitico marrom constituindo um manto sobre as zonas planas e baixas do distrito. De saparece nas encostas suaves dos morros ou em pequenas elevações

Foto 6 - Solo ferralitico amarelo que se forma sobre piroxenito, peridotito ou dunito, sendo mais espesso e rico em $\mathrm{Ni}$ sobre esta ültima rocha

Foto 7 - Dunito alterado, com verde escura com manchas marrons. Fragmentos grosseiros predominantes. Al to teor de $\mathrm{Ni}$

Foto 8 - Peridotito serpentinizado alterado. Cor verde mais clara, maior percentagem de finos e teor de $\mathrm{Ni}$ inferior em comparação ao dos dunitos

Foto 9 - Piroxenito alterado constituindo material pre dominantemente fino, cor verde clara, às vezes amarelada. Os teores de $\mathrm{Ni}$ são baixos

Foto 10 - Furo 27 - Profundidade de 6,3m. Dunito parcial mente serpentinizado, com relictos de olivinas - opacos - Nicóis descruzados. Aumento $20 \mathrm{X}$.

Foto 11 - Furo 1-Profundidade de $61 \mathrm{~m}$. Peridotito com cristal de olivina parcialmente serpentinizado. Piroxênio predominante, com agulhas finis simas de rutilo(?). Biotita e opacos. Nicōis descruzados. Aumento $20 \mathrm{X}$

Foto 12 - Furo 6 - Profundidade de 47,5m. Piroxenito com opacos. Nicóis descruzados. Aumento $20 \mathrm{X}$ 
Foto 13 - Missourito, com piroxênio (Pi) predominante, leucita(Le) e opacos. Nicöis descruzados.Aumento $20 x$

Foto 14 - Malignito - Textura poiquilitica mostrando fenocristais de ortoclasio (Or) englobando nefelina(Ne), piroxenio, biotita e opacos. Ni cöis semi-cruzados. Aumento $20 \mathrm{X}$

Foto 15 - Furo 27 - Profundidade de 5,8m. Dunito pouco serpentinizado - Minerais opacos - Nicóis cru $z$ ados - Aumento $20 \mathrm{X}$

Foto 16 - Furo 27 - Profundidade de 78,9m - Serpentini zação acentuada por processo ascendente. Relictos de olivina - Nicōis descruzados. Aumento $20 \mathrm{X}$

Foto 17 - Lāmina delgada de zona de alteração hidroter mal. Perowskita escura envolvida por magnesi ta cinza clara, olivina serpentinizada cinza escura com opacos e cristais de mica(Mi)-Nicōis descruzados. Aumento $20 \mathrm{X}$

Foto 18 - Seções A-1 a A-7 - Micrografia eletrōnica e microssonda de seção polida de zona de alteração hidrotermal. Perowskita rica em Ca, Ti e algum $\mathrm{Nb}$; magnetita rica em $\mathrm{Fe}$ e ilmenita rica em $\mathrm{Ti}$

Foto 19 - Escalonamento da topografia formado por um sistema de fraturas. Morro do Tirapressa

Foto 20 - Sistema de fraturas circulares provocando um aparente "descascamento" do Morro do Tirapressa. A dimensão não permite representação no mapa. Ao fundo maciço gnäissico capeado pe Io Arenito Furnas.

Foto 21 - Sistema de fraturas circulares, paralelo ao plano da foto, visível tambēm no morro ao fun do. Outro sistema perpendicular ao primeiro, visivel no morro em primeiro plano. As faixas escuras são desniveis topogräficos provocados pelos planos de fratura

Foto 22 - Sistema horizontal de fraturas em zona de dunitos serpentinizados. Morro do Tirapressa 
Foto 23 - Concreções ooliticas soltas, imersas em mas sa ferruginosa fina. Alguns pisolitos dispersos (tamanho natural)

Foto 24 - Concreções oolitica soltas. Microscópio ele trónico de varredura. Aumento $100 \mathrm{X}$ Foto 25 - Foto de concreções pisoliticas soltas no so

Foto 26 - B-1 a B-5 - Micrografia eletrōnica e micros sonda - Elementos $\mathrm{Ni}$ e Co dispersos, respec tivamente, nas seções $\mathrm{B}-3$ e $\mathrm{B}-4$. Na seção $B-2$, cristal de ilmenita. Seção $B-5$ com cristais de cromita. Notar que onde ocorre cromita $(B-5)$ a porcentagem de $T i(B-2)$ ele vada. Para identificação completa da jimen ta e cromita, ver Capittulo IX

Foto 27 - C-1 a C-8 - Micrografia e microssonda. A dis tribuição do $\mathrm{Cr}, A \mathrm{l}$ e Co é preferencial. De ve corresponder a um cristal de cromita, em cuja fōrmula $\overline{\mathrm{e}}$ admitido tambēm $\mathrm{Al}$. $0 \mathrm{Fe}$ com pensa negativamente o $\mathrm{Cr}$; $\mathrm{Ni}, \mathrm{Si}$ e $\mathrm{Mn}$ estão 76 dispersos homogēneamente na seção

Foto 28 - D-1 a D-4 - Microssonda eletrōnica e micros sonda. $\mathrm{Fe}, \mathrm{Cr}$ e $\mathrm{Ni}$ estão dispersos, sem distribuição preferencial na composição, indicando um cimento homogêneo, se bem que hete rogêneo no aspecto físico. O Cr apresentase levemente concentrado em alguns pontos, mas não chega a caracterizar a presença dé cromita agregada na concreção

Foto 29 - Controle estrutural dos vejos de vermiculita fina. Rocha encaixante $\bar{e}$ um dunito. Morro do Tirapressa.

Foto 30 - "Xenōlito" de dunito (Du) dentro de um veio de vermiculita(Ve) fina. Região Sul do Tira pressa.

Foto 31 - Placas de vermiculita grosseira, sem orientação preferencial. Dimensão máxima de 25 $\mathrm{cm}$. Regiäo $S$ do Tirapressa

Foto 32 - Vênulas de calcedōnea em fraturas predominantemente horizontais. Encosta dunitica do morro do Tirapressa 
Foto 33 - Microfraturamento paralelo preenchido por.silica de cor branca

Foto 34 - "Box Work" silicoso, de coloração branca.Morro do Tirapressa

Foto 35 - Crosta maciça de calcedonea, de coloração bran ca ou rosada. Restos de ultramáfica alteradä englobados. SW do Morro do Tirapressa

Foto 36 - Seções de E-1 a E-6 - Micrografia eletrōnica e microssonda. Magnetita com lamelas de ilmenita. A ilmenita e menos rica em Fe, mas contém bastante $\mathrm{Ti}_{i}$ e algum $\mathrm{Mg}$ e $\mathrm{Mn}$

Foto 37 - Martitização(cinza-claro) da magnetita (cinza médio) ao longo dos planos (111). Notar lamelas de ilmenita (cinza mais escuro) delgadas, seguindo o mesmo sistema. Escala: $440 \times$. Seção APB 102

Foto 38 - Seções F-1 a F-5 - Micrografia eletrônica e microssonda. Maghemita com lamelas de ilmenita ao longo dos planos (111) da magnetita transformada. Superfície picotada e a ilmenita resistindo à oxidação

Foto 39 - Lamelas de ilmenita em um dos planos (111) da magnetita. Notar martitização da magnetita ao longo de uma zona de fratura. Ilmenita cinza escura; magnetita cinza mais clara e hematita formada por martitização, cor cinza bem clara. Aumento $128 \mathrm{X}$

Foto 40 - Seções G-1 a G-5 - Micrografia eletrônica e microssonda. Magnetita titanifera;alguns cris tais tem mais Ti que outros. Notar que cristais são idiomörficos

Foto 41 - Galena (cinza mais clara) com marcas triangulares incipientes e riscos de polimento. I ime nita cinza clara, e ganga, cinza escura. Au= mento $320 \mathrm{X}$ 


\section{TABELAS}

Tabela 1 - Profundidade do nível hidrostātico em função da distäncia aos cörregos - topografia plana

Tabela 2 - Concentrados naturais de minerais opacos

Tabela 3 - Anālise quĩmica do solo ferralītico marrom

Tabela 4 - Nümero de amostras coletadas segundo a litologia e a topografia

Tabela 5 - Anālise química de agregado de ilmenita e magnetita - Amostra SF-502

Tabela 6 - Anālise química de agregados de minerais de magnetismo forte

Tabela 7 - Anālise química de agregados de minerais de magnetismo fraco

\section{ANEXO}

Figura 3 - Mapa geolögico do distrito de Santa Fē

Figura 4 - Mapa geológico e locação dos poços e furos 
CAPITULO I

\section{INTRODUÇAO}

0 maciço ultramäfico de Santa Fë estä situado a NW do Municipio de Jussara, Estado de Goiās, e foi estudado por värias companhias particulares, com vistas ao seu conteūdo de $\mathrm{Ni}$ e de vermiculita. Dada a sua litologia, algumas tentativas tambëm foram feitas para verificar a presen ça de elementos associados a rochas alcalinas e, em alterna. tiva mais remota, a carbonatitos.

A Companhia de Pesquisa de Recursos Minerais execu tou para o DNPM trabalhos de mapeamento regional, visando ca racterizar a faixa serpentinica que corta o Estado de Goias e que se extende para o norte.

Nos ültimos anos, a Mineradora Montita Ltda. exe cutou extensivos trabalhos de pesquisa para $\mathrm{Ni}$, acu mulando numerosos dados quimicos de superfície e subsuperfí cie. A geologia parcialmente conhecida, assim como a disponibilidade de inümeras anälises químicas de poços e furos de sondagem, induziram o autor a iniciar uma pesquisa acadé mica, buscando definir os principais traços geolōgicos da jazida.

De setembro de 1973 a novembro de 1975 foram feitas värias campanhas de campo, de modo a elaborar um mapa geolögico da ärea e coletar amostras representativas de per fis horizontais e verticais.

Os trabalhos de campo foram baseados em mapas topo gräficos de grande parte do distrito e em fotografias 
aēreas cedidas pela Companhia Montita. Esta companhia forneceu, tambēm, resultados de anālises quĩmicas e colocou ā nossa disposição testemunhos de sondagem e meios para executar os trabalhos de campo.

A região de Santa Fé estā contida na superfĩcie denominada "Planaltos Cristalinos da Bacia Araguaia-Tocantins" e, segundo Geiger (in GALVAO,M.V., 1960), é cortada pelos afluentes do Rio Araguaia, apresentando altitudes mëdias variāveis de 300 a $600 \mathrm{~m}$.

0 maciço e ressaltado na topografia local apenas atraves dos testemunhos de erosão, que são constituidos de morros isolados a $N$ e de um espigão continuo a $S$, denominado Serra do Tirapressa.

A pluviosidade mëdia anual da região estā em torno de $1.700 \mathrm{~mm}$, com isoietas mëdias de verão (dezembro,janeiro, fevereiro) de $770 \mathrm{~mm}$ e isoietas mëdias de inverno (junho,ju1ho, agōsto) de $25 \mathrm{~mm}$. Os meses de outubro a abril representam mais de $80 \%$ da precipitação anual. Segundo Köppen,o clima da ārea ē classificado como Aw, correspondendo a savanas tropicais, com verão ümido e inverno seco.

A vegetação local è do tipo cerrado ou, segundo fitogeōgrados, "savana" com vegetação arbustiva, constituída de individuos espaçados, adensados apenas ao longo das "matas galerias". Alguns destes aspectos são vistos na Foto 1.

A alteração das rochas do distrito, especialmente os dunitos, peridotitos e piroxenitos, levou à formação de uma capa de alteração enriquecida em $N i$, coberta em suas zonas mais baixas por um solo ferralitico de cor marrom. Veios de vermiculita, com comprimento, espessura e profundidade varia 
veis, cortam a ultramäfica alterada aflorante e estão associados, localmente, a agregados de minerais opacos disseminados.

Dunitos, peridotitos e piroxenitos, associados a pequenas intrusões de gabros alcalinos, cortam gnaisses prē-cam brianos que são as rochas regionais.

\section{CAPITULO II}

\section{TRABALHOS ANTERIORES}

Menção à geologia do distrito e seus depōsitos nique İ̃feros foi feita por värios autores, entre eles ANGEIRAS (1968), BERBERT (1970) e SCHOBBENHAUS FILHO (1975).

Em 1971, a Companhia de Pesquisa de Recursos Minerais, Agência Goiānia, imprimiu um relatōrio denominado "Geologia da Quadricula de Britânia, Santa Fē, Araguapaz e Jussara: Projeto Jussara", de autoria de M.L.Sobrinho e R.S. Andra de. Foi elaborado um mapa geológico do distrito, na escala $1: 50.000$, com observações gerais sobre a geologia local. Naquele mesmo ano foi apresentado um resumo no $x \times V$ Congresso Brasileiro de Geologia, realizado em São Paulo, onde M.L. Sobrinho e R.S. Marques descreveram missouritos e rochas alcali nas associadas do distrito de Santa $\mathrm{F} \vec{e}$. Ainda em 1971, Linden mayer fez uma previsão da estimativa de reservas de minērió e de $\mathrm{Ni}$ contido no distrito.

Pesquisas de $\mathrm{Ni}$ e de vermiculita foram efetuadas no distrito por companhias particulares, sem, entretanto, terem sido divulgados os resultados obtidos. 
Em 1972, Axel de Ferran apresentou relatörio à Terraservice Projetos Geolögicos Ltda. sobre pesquisa geo quîmica e estimativa de reservas de $\mathrm{Ni}$. Os resultados des te relatōrio interno são desconhecidos.

Em 1975, a Mineradora Montita Ltda. entregou ao DNPM relatōrio de pesquisa de $\mathrm{Ni}$ de parte da jazida, deno minado "Projeto Santa Fē - Relatōrio de Pesquisa". Neste relatōrio inēdito, a litologia do distrito é mais pormeno rizada, distinguindo-se os contatos entre os dunitos, peri dotitos e piroxenitos. Consta do mapa geolögico a localizá ção de dioritos e missouritos.

\title{
CAPITULO III
}

\author{
METODOLOGIA
}

Os trabalhos de campo foram desenvolvidos entre se tembro de 1973 e novembro de 1975, em campanhas corresponden tes aos periodos de fërias escolares. Os resultados obtidos do estudo de fotografias aēreas da ārea, descrição e anālise de amostras foram lançados em um mapa topogräfico, na escala 1:10.000, que cobre 4/5 da região levantada. Tratando-se de uma ārea de intrusão com dimensões aproximadas de 9,5 por $6,5 \mathrm{~km}$, constituida de 12 morros isolados e uma maciço contI nuo e com um nümero de poços perfurados superior a 1.250, os trabalhos de campo foram extremamente prolongados e exigiram a descrição e amostragem de grande parte dos poços localiza- 
dos na ultramäfica. Essa descrição e amostragem foram feitas descendo nos poços por meio de cordas suspensas e enroladas em um saritho. Poços desmoronados ou inacessiveis foram descritos pelo material correspondente a segmentos de um metro, retirados e depositados na borda imediata dos poços.

As anālises quĩmicas por via ümida e absorção atōmi ca foram efetuadas pelo Dr. Raphael Hypölito, do Departamento de Mineralogia e Petrologia, nos laboratōrios do Instituto de Geociēncias da Universidade de São Paulo, com resultados em $\mathrm{SiO}_{2}, \mathrm{TiO}_{2}, \mathrm{Al}_{2} \mathrm{O}_{3}, \mathrm{Fe}_{2} \mathrm{O}_{3}, \mathrm{FeO}, \mathrm{MnO}, \mathrm{MgO}, \mathrm{Cr}^{3+}, \mathrm{CaO}$, $\mathrm{Na}_{2} \mathrm{O}, \mathrm{K}_{2} \mathrm{O}, \mathrm{H}_{2} \mathrm{O}^{-}$e $\mathrm{H}_{2} \mathrm{O}^{+}$. Anälises complementares de $\mathrm{Sn}$, $\mathrm{Sb}$, Mo, $\mathrm{Nb}, \mathrm{Ga}, \mathrm{Sr}, \mathrm{Rb}, \mathrm{Zr}, \mathrm{Ni}, \mathrm{Cr}, \mathrm{TiO}_{2}, \mathrm{Y}, \mathrm{Pb}, \mathrm{Zn}, \mathrm{Th}, \mathrm{Cu}$ e Co, foram efetuadas pelo Dr. Marcos Berenholc, do Departamento de Geologia Geral, no laboratörio do Centro de Pesquisas Geo cronolōgicas do Instituto de Geociências, utilizando fluores cência de raios $x$.

As anälises químicas dos perfís de poços, encaminha das pela Companhia Montita de Mineração S.A., foram efetuadas pela Companhia Geologia e Sondagens Ltda. (Geosol) e pela Metais de Goiäs S.A. (Metago). Ni, Mgo, Fe, Co e Cr foram dosados por espectrografia ōptica, absorção atōmica e fluom rescência de raios $x$.

As lâminas delgadas foram estudadas em microscōpio ortolux-pol, de fabricação Leitz. A descrição do grau de ser pentinização das olivinas do Furo 27 foi efetuada atravēs de contagem de pontos, com espaçamento adequado à granulação da rocha, com valor mëdio de 300 pontos por lämina.

Um total de 75 seções polidas de minerais opacos e concreçoes ooliticas e pisoliticas foi estudado em microscōpio de luz refletida de fabricação Reichert.

värios espectros de difração de raios $x$ de amostras 
totais e de minerais separados foram obtidos no difratōmetro Philips-Norelco do DMP. Em geral, os difratogramas foram obtidos utilizando-se radiação $C u K \alpha$, velocidade de giro de amostra $=2^{\circ} \theta / \mathrm{min}, 35 \mathrm{KV}, 15 \mathrm{~mA}$, velocidade do papel de $30 \mathrm{~cm} / \mathrm{min}$, varredura de $2 \theta$ entre 2 e $80^{\circ}$.

0 estudo da alteração da ultramäfica e corresponden te enriquecimento de $\mathrm{Ni}$ foi complementado por determinações de peso especifico aparente, em amostras coletadas ao longo de um perfil de solo. As determinações de amostras coesas fo ram feitas em balança de peso especĩfico, do tipo Westphal Mohr, do DGG. Os valores finais obtidos foram corrigidos, pe 10 fato das amostras porosas terem sido envolvidas em parafi na.

Amostras incoerentes foram colocadas em provetas graduadas, onde foi obtido o volume aparente, tendo sido, en tão, calculado o peso específico aparente.

Seções polidas foram preparadas para estudo da concentração de elementos por meio de microssonda eletrōnica. 0 Prof. Dr. Kenkichi Fugimori utilizou aparelho do tipo JAX-5, com as seguintes características:

- Voltagem de aceleração: 5 a $50 \mathrm{kV}$;

- Vācuo: $10^{-5}=10^{-6} \mathrm{~mm} \mathrm{Hg}$;

- Amperagem: $10^{-5}-10^{-9} \mathrm{~A}$

Nesta técnica de estudo, denominada Variação Bidimensional, a concentração do elemento ē proporcional ao nūme ro de pontos brilhantes detectados no papel fotogräfico. Foi uma tēcnica auxiliar ütil para a determinação de alguns mine rais opacos e tambēm para verificação da dispersão e associa ção dos elementos entre si nas camadas constituintes das con creções lateriticas.

o Prof.Dr. Gildo Fuck providenciou as anālises ter- 
modiferenciais de polimorfos de serpentina. Esta tēcnica foi utilizada em aparelho Rigaku Thermoflex, com termopar de Pla tinel-Alumel e provido de registrador gräfico, pertencente ao Departamento de Geologia Geral do Instituto de Geociēncias.

\section{CAPITULO IV}

\section{LOCALIZAÇAO GEOGRAFICA}

A cidade de Santa $F \bar{e}$ possui coordenadas geogrāficas de $15^{\circ} 40^{\prime}$ de latitude $S$ e $51^{\circ} 15^{\prime}$ de longitude $W$ e estä 1ocalizada a $130 \mathrm{~km}$ a $W$ de Goiäs Velho. O corpo ultramäfico, objeto deste trabalho, dista $3 \mathrm{~km}$ a NW desta cidade, motivo pe 10 qual recebeu o mesmo nome.

De Goiânia, ponto comum para todos que se encaminham para $W$, Goiās Velho dista $150 \mathrm{~km}$ por pista asfaltada (Figura 1). Segundo previsões do "Prodoeste", uma via asfaltada, passando a $14 \mathrm{~km}$ a S de Santa Fë, deverä ligar BrasíIia a Cuiabā. 0 contato leste do maciço é tangenciado por uma estrada estadual (G0-28) que liga Santa Fé a N,Britânia, em. direção ā bacia do Rio Araguaia. 


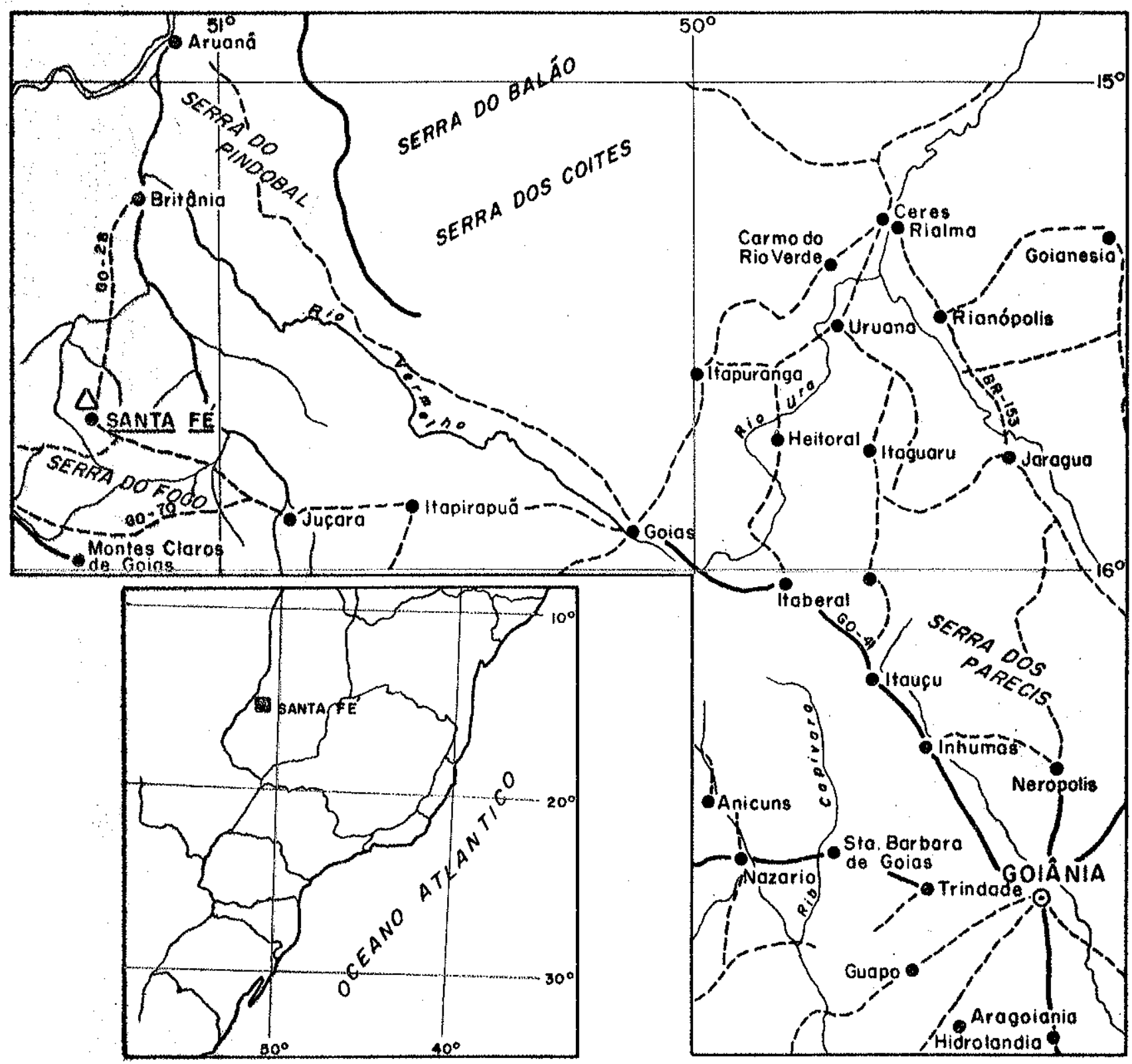

LEGENDA

$\triangle$ Distrito de Santa Fé $Y$ Estradas pavimentadas

- Capital

- Cidades i) Estradas transitáveis Yhrios

Fig. I - MAPA DE LOCALIZAÇẢO DA ÁREA DE SANTA FÉ 


\section{CAPITULO $V$}

\section{RELEVO DO DISTRITO}

O relêvo da região è caracterizado por duas unidades morfologicamente distintas: uma, a predominante no distrito, que é constituída de uma superfĩcie plana, baixa arrasada, co berta por lateritas concrecionärias ooliticas soltas, localmente cimentadas, e formando crostas; e, outra que $\vec{e}$ represen tada pelos morros testemunhos de dunitos, com a ünica exceção de parte do Morro Caiçara, localizado na ārea IV. A altitude predominante da primeira unidade situa-se entre 420 e $450 \mathrm{~m}$, com suave declive para $N$ em direção à bacia do Rio Araguaia, visto a NW da Foto 1. A zona rasa desenvolveu-se sobre gnaisses, dunitos, peridotitos e piroxenitos serpentinizados, ro chas alcalinas associadas e litologias menores. Apenas os dur nitos formam morros isolados e linhas de cumeadas outras 1itologias são mais facilmente arrasadas pela erosão.

Parece que o fato da alteração do dunito levar a uma rocha menos desagregāvel do que o piroxenito e, tambēm, mais ferruginosa, dā, como produto final, uma rocha estruturada,co berta de blocos mais resistentes ao intemperismo fisico. Esta rocha preserva mais facilmente as elevações do distrito. 0 p roxenito alterado $\bar{e}$ extremamente friāvel, fino, adquirindo as pecto argiloso, facilitando sobremodo a alteração e erosão da capa superficial intemperizada. Os peridotitos, quando altera dos, tem caracteristicas mëdias entre os dunitos e os piroxenitos.

Vale observar que o dunito que constitui os morros 


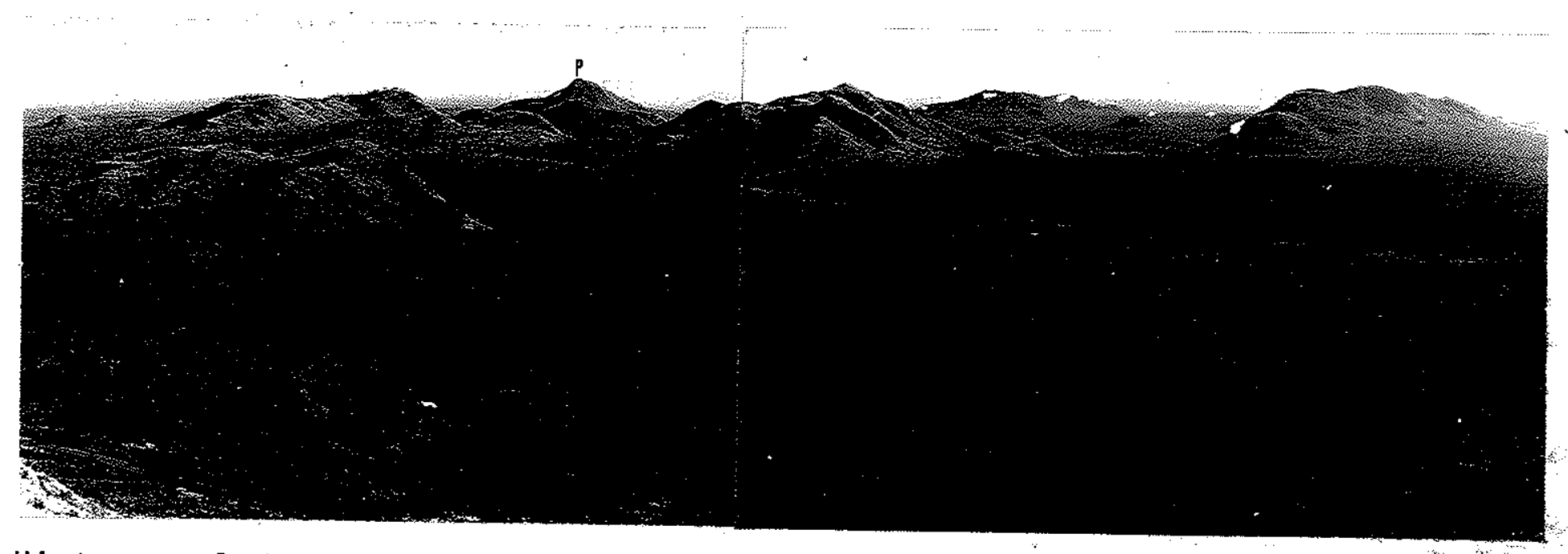
Foto 1 - Vista geral do distrito, olhando para NNW. Zona rasa e baixa central (dunito),
circundada por morros arredondados de dunito. Ao fundo, no centro da foto, ci-
clo de aplainamento clo de aplainamento em arenitos com costão junto ao Morro Pontal (P). A W, região mais baixa e plana do vale do Araguaia. 


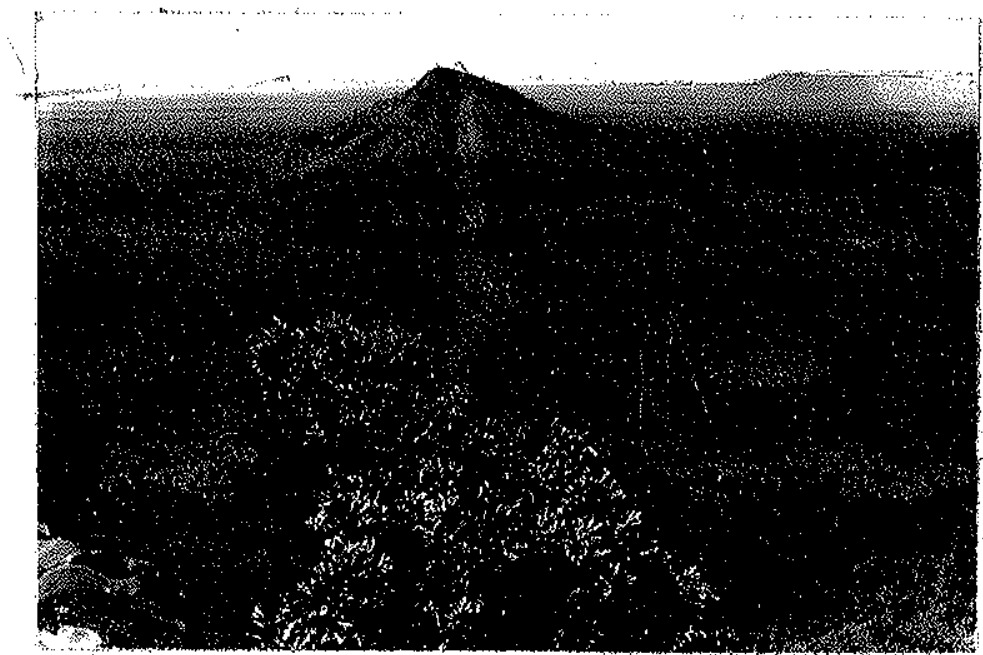

Foto 2 - Vista do Vale do Araguaia para NW. Zona baixa, plana com o Morro do Pontal, que $\overrightarrow{\mathrm{e}}$ um testemunho do nỉvel de erosão que atingiu tambëm a superficie aplainada ao fundo, à direita, e que são rochas sedimentares e ultramāficas capeadas por uma crosta de calcedônea. 
do Tirapressa tem uma textura diferente e se enriquece menos de $\mathrm{Ni}$, possivelmente partindo de rocha portadora com "def $\underline{\mathbf{i}}$ cit" de Ni. Parece vālido inferir que corresponde a outra in trusão, diferente daquela que originou as zonas duniticas do restante do distrito. A cor do produto de alteração, a textú ra, a presença mais comum de vênulas de calcedônea e os teores de $\mathrm{Ni}$ inferiores falam por si sō de uma intrusão distinta. Alēm do mais, a tectōnica local denota esforços horizontais, que não são exatamente os mesmos do resto da tectōnica do distrito.0 Tirapressa, que estā localizado ao sul do distrito, constitui um maciço grupado de morros, diferente do estilo isolado do restante das elevações. As altitudes mēdias do distrito são as seguintes:

$\begin{array}{ll}\text { Região } & \text { Altitude mëdia } \\ \text { Planura } & 400 \text { a } 450 \mathrm{~m} \\ \text { Morros } & 550 \mathrm{~m} \text { (excepcionalmente mais) } \\ \text { Tirapressa } & 650 \mathrm{~m}\end{array}$

os morros testemunhos da ultramäfica, assim como platô de calcedônea onde se localiza o distrito de Agua Bran ca, a N (Foto 2), constituem uma só superfície semi-áplaina. da, com altitude mëdia de 550 a $650 \mathrm{~m}$. A erosão regional atual estă orientada para a rede hidrogräfica que se extende para o vale do Rio Araguaia, localizado a NW do distrito.

CAPITULO VI

EVOLUÇAO MORFOLOGICA DO DISTRITO

Uma anālise do relevo atual do Distrito de Santa Fé 
indica claramente formas remanescentes de um relevo antigo, a plainado, submetido a um processo contīnuo de rejuvenescimen to em um rítmo de erosão mais räpido do que aquele que permi tiria o enriquecimento das ultramäficas em Ni. A destruição sistemātica das crostas de calcedōnea com a consequente formação de eluviões de blocos, assim como a existēncia de crostas lateríticas em zonas baixas, tambēm submetidas ā degradação física, falam por si sö do régime acelerado de denu dação da regiäo.

A reconstituição da evolução geomorfolögica do distrito $\vec{e}$ possível, pelo menos, se evidenciarmos apenas os fenômenos geolōgicos mais marcantes que deixaram vestigios para correlações diretas ou indiretas com outros fenōmenos sub sequentes.

A evolução deve se ter operado em ciclos, cuja sequēncia ē esquematizada genericamente a seguir:

10 Ciclo - Aplainamento das rochas regionais e 10cais

Apōs a intrusão da ultramāfica, as rochas foram sub metidas a um longo e ativo processo de aplainamento, evidenciado pelo nivelamento regional do topo dos morros do Distri to de Santa $F \bar{e}$, do gnaisse capeado pelo Arenito Furnas,a $S S W$, e pelo Arenito Furnas intercalado com ultramäficas e capeado por calcedónea no distrito de Agua Limpa, a NNW. Tanto quanto se pode depreender dos remanescentes deste periodo, deve ter sido prē-Terciārio, com a formação da calcedōnea em croș tas locais. Esta silicificação, aliada a diferenças litolögi cas, mesmo diferenças do prōprio dunito, criou condições para que uma erosão seletiva iniciasse o desnivelamento da superficie aplainada (Ver Figura 2-I). 


\section{Ciclo - Erosão e desnivelamento da superficie re- gional}

A alteração das rochas, seguida de erosão de um subs trato litologicamente diferente, culminou com a formação de zonas proeminentes onde prevaleciam dunitos, mesmo com silici ficação incipiente. 0 arenito Furnas, a SSW, cimentado pela prōpria sîlica, e a ärea denominada Agua Limpa, a NNW, coberta por uma espessa capa de calcedōnea, permaneceram, a partir deste ciclo, como testemunhos da pretērita superfície de aplainamento. As zonas baixas foram denudadas ao nivel da dre
nagem regional.

\section{Ciclo - Laterização}

Estabilidade do perfil de equilíbrio por um período que permitiu a formação de lateritas locais nos vales suspensos intermontanos, nas encostas suaves e nas zonas baixas niveladas segundo a altitude mëdia regional.

40 Ciclo - Rejuvenescimento e degradação mecânica

Degradação mecãnica das lateritas e das crostas de calcedōnea, evidenciada pelos eluviões de blocos de calcedónea e pelas lateritas baixas cortadas pelos pequenos cōrregos ou torrentes de vales em regime fluvial intermitente. Erosão mais intensa nos topos e nas encostas dos morros, com remoção acelerada do serpentinito superficial enriquecido em $\mathrm{Ni}$.

\section{CAPITULO VII}

GEOLOGIA GERAL

A correlação cronolögica da ultramäfica de Santa : Fë 


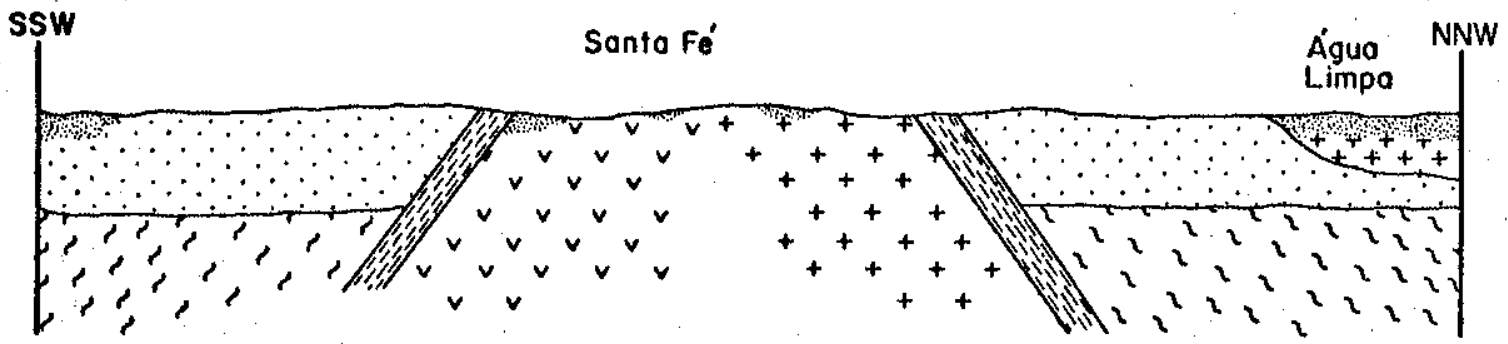

1 - Peneplonizaçöo com silificaçöes locais

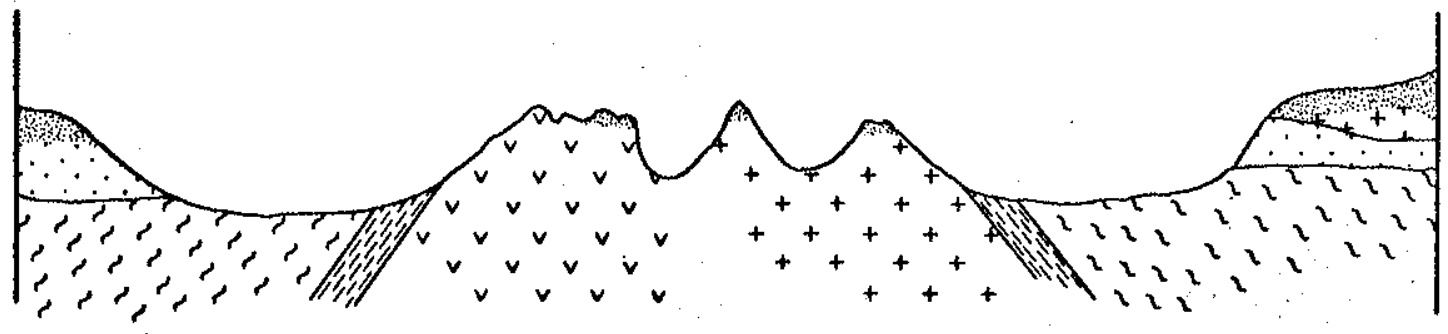

II - Erosōo diferencial e formaçõo de relêvo dissecado

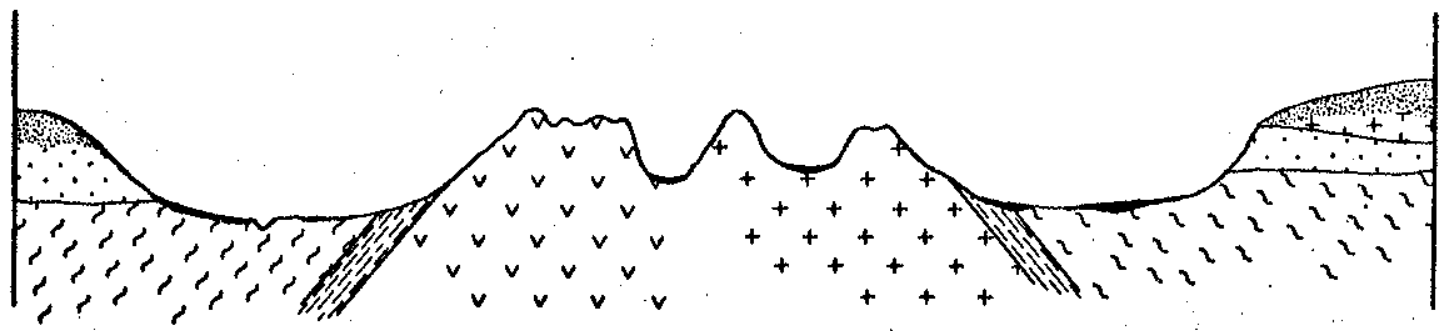

\section{HII - Laterizocão}

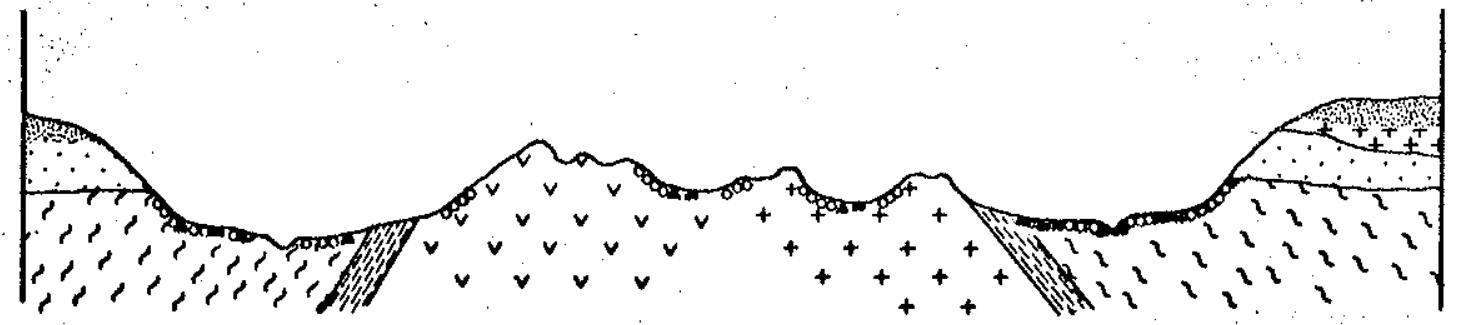

IV-Rejuvenescimento com degradoçảo mecônica das lateritos e crostas de calcedônea.

\begin{tabular}{|c|c|c|}
\hline 30 & Rolodo-Colúvio & 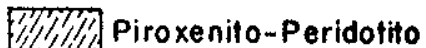 \\
\hline 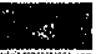 & Laterifos & $\begin{array}{l}\text { Arenito Furnas } \\
\text { Retrabalhodo }\end{array}$ \\
\hline & Colcedôneo & P? Gnaisse \\
\hline & Dunit & mo sem escalo \\
\hline
\end{tabular}

Fig. 2- ESQUEMA DA EVOLUÇAO MORFOLÓGICA DO DISTRITO 
com as rochas locais e sua posição na coluna estratigräfica exigem algumas considerações bibliogräficas. A borda oriental da Bacia do Paranā estā delimitada grosseiramente por uma faixa descontinua de complexos alcalinos conhecidos na bibliografia por suas peculiaridades genëticas. Essas intrusões, cujas dimensões são variāveis, desde diques atē maciços com värias centenas de $\mathrm{Km}^{2}$, que se localizam na periferia da Bacia do Parană, em sua quase totalidade possuem idades entre 50 e 90 milhões de anos.

Considera-se o maciço de Santa $F \bar{e}$ de idade cretācica, pertencente ao Grupo Iporá. Este grupo foi definido por GUIMARAES et a.1.(1968) e contëm rochas que variam desde ultramāficas ate rochas graniticas, sendo correlacionadas ao vulcanismo alcalino da borda da Bacia do Paranä. Recebeu o nome de um maciço ultramāfico localizado pröximo à cidade de Iporä, a $80 \mathrm{~km}$ a $S W$ de Santa $F \vec{e}$.

PENA \& FIGUEIREDO (1972), baseados em observações regionais de dados estruturais e correlação estratigrāfica, assim como datações radiomētricas, colocam o Grupo Iporā no cretāceo superior. os termos mais bäsicos do grupo são considerados mais antigos, passando a uma sequencia mais nova de rochas intermediärias e, finalmente, äcidas. A Formação Furnas, assim denominada por OLIVEIRA (1912), è constituída de arenitos grosseiros e mal selecionados, sendo considerada, de idade devoniana. Esta formação è cortada pelos maciços de Iporā e Agua Limpa, ambos considerados contemporāneos ao maciço de Santa $F \vec{e}$. No distrito restou apenas uma cobertura arenosa recente, provavelmente produto do retrabalihamento do Arenito Furnas que nele não ocorre.

As relações regionais entre o embasamento, Grupo Iporā e. Formação Furnas podem ser verificadas na folha Goiās - SD - 22 da Carta Geológica do Brasil ao Milionésimo, DNPM, 1975. 
Apōs estas considerações de carāter regional, destaca-se a geologia local do maciço, constituído de um corpo ovalado, com maior diāmetro na direção $\mathrm{N}-\mathrm{S}$, medindo aproxima damente 9,5 por $6,5 \mathrm{~km}$.

0 maciço corta gnaisses regionais com direção prefe rencial NNW e mergulho acentuado para $S W$. Segundo se observa no mapa geolögico da Figura 2 e no perfil $A B$, a distribuição das rochas do distrito indica uma estrutura em domo zonado, com um nücleo de dunito serpentinizado envolvido por camadas descontinuas e concēntricas de peridotitos e piroxenitos, seguidas de manchas da encaixante gnäissica afetadas por metamor fismo de contato, e, finalmente, pequenas intrusöes dispersas de rochas alcalinas. Foram observados diques de piroxenj tos cortando os dunitos e os peridotitos, provocando fenómenos de recristalização nas bordas imediatas do contato.

TAYLOR (1960), NOBLE (1960) e RUCKMICK(1969) descre veram, pormenorizadamente, intrusões ultramäficas zonadas da região SE do Alaska. No distrito de Santa Fē o zoneamento mais nitido, talvez pelo fato da litologia ser mais simples.

Gnaisses envolvem todo o maciço ultramäfico,mas, na porção $N$, esta rocha é capeada por rochas sedimentares prove nientes, principalmente, do intemperismo e remanejamento do Arenito Furnas, formando uma delgada cobertura sobre o embasamento, denominada cobertura areno-argilosa.

Antecipando a descrição das rochas, que serä fejta em um dos capitulos seguintes, cumpre observar que o dunito, na ärea $N$ e $S$ do distrito, apresenta variações físicas e, em parte, quimicas, deixando supor que o nücleo dunītico é formado por intrusões müitiplas.

Vārios furos de sondagem rotativa atravessaram as rochas do distrito ate profundidades superiores a $60 \mathrm{~m}$. Den- 
tre estes furos foram selecionados dois, o nümero 2, (Figura 5), que corta piroxenito e termina em peridotito, e o número 18, (Figura 6), perfurado inicialmente em dunito serpentinizado. Entre estes dois furos, diferenças provenientes da $1 i-$ tologia e perfil de alteração deram origem a características distintas. Dentre estas, vale ressaltar as seguintes:

0 furo no 2 passa de solo ferralítico marrom para amarelo, voltando novamente a solo ferralitico marrom antes de atingir o piroxenito alterado. Mesmo localizado em piroxe nito, o teor de $\mathrm{Ni}$ chega a atingir, em um pequeno segmento, $1,1 \%$, valor este alto demais para tal tipo de rocha. Segundo se pode notar no mapa da Figura 3 , a mancha de piroxenito on de se acha este furo estā rodeada de peridotitos, que devem ter fornecido o $\mathrm{Ni}$ em sucessivas solubilizações e precipitações laterais.

O teor de $\mathrm{Ni}$ não apresenta acrëscimo sensĩvel na zo na de solo ferralitico amarelo, comumente bastante enriquecido naquele elemento em perfis localizados em dunitos. Aliās, - solo ferralítico amarelo devia se colocar entre o solo fer ralitico marrom acima e o piroxenito alterado abaixo.

0 furo nọ 18 não apresenta em seu perfil o solo fer ralittico amarelo. 0 grau de silicificação e incipiente, mantendo, desde os primeiros metros de perfuração, teores me dios de $N i$ mais elevados. Este teor vai caindo com a profundidade, mantendo-se, entretanto, acima de $0,2 \%$. 0 piroxenito pode, por sua vez, apresentar teores de $\mathrm{Ni}$ inferiores a $0,2 \%$.

A despeito da litologia diferente, o solo de ambos os furos mostra caracteristicas fisicas homogēneas que impedem a identificação da rocha subjacente. Em condições normais, nota-se diferença apenas na composição química, especialmente quanto a porcentagem de $N i$, que é indicativa, muitas vezes, do tipo de rocha encontrada em subsuperfície. 
Algumas suaves elevações do distrito estão cobertas por delgados eluviões de minerais opacos. Estes são provenientes da alteração da ultramäfica, que contëm estes minerais dispersos ou em delgadas vênulas. As vēnulas são comuns em zonas com veios de vermiculita. Segundo pode ser verifica do no mapa da Figura 4, foram delimitadas algumas äreas de eluviões nos dunitos da zona central $N$ do distrito, que cons titui uma zona rasa, baixa, com morros isolados. No Tirapres sa não foram localizados eluviões de opacos, correspondendo a uma ārea onde estes se acham muito disseminados. Coinciden temente, a vermiculita é tambëm menos comum.

\section{VII.I - ROCHAS E SUA IDENTIFICAÇÃO}

Para a elaboração do mapa geológico do distrito e o conhecimento da distribuição das diferentes rochas, foram es tudadas amostras coletadas em afloramentos, furos de sonda e poços, principalmente nestes ültimos. 0s poços forneceram mais de $90 \%$ das informações necessārias à classificação e de limitação das rochas olivĩnicas do distrito.

A anālise petrogrāfica das rochas do distrito ē pre liminar, atendendo apenas ao objetivo do mapeamento geológico, sem orientação de carāter genētico. Alëm disto, a serpen tinização e a alteração superficial dificultaram a identificação das amostras descritas nos poços de amostragem. Localmente, furos de sonda prōximos permitem a delimitação do zoneamento litolögico subsuperficial do macico, assim como dos contatos com as encaixantes. 


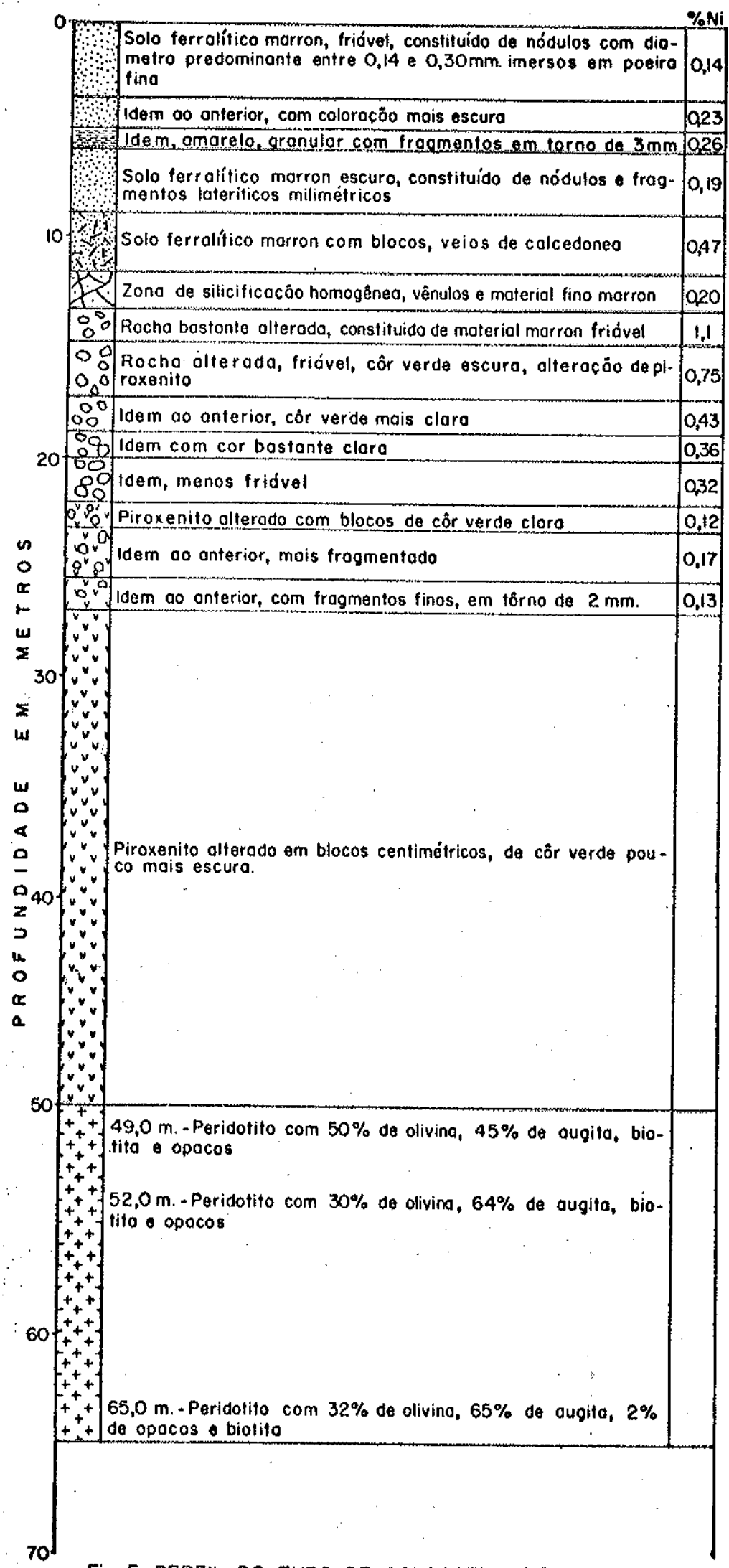

Fig. 5 _PERFIL DO FURO DE SONDAGEM NN2, 47+50 W, EM PIROXENITO E PERIDOTITO 


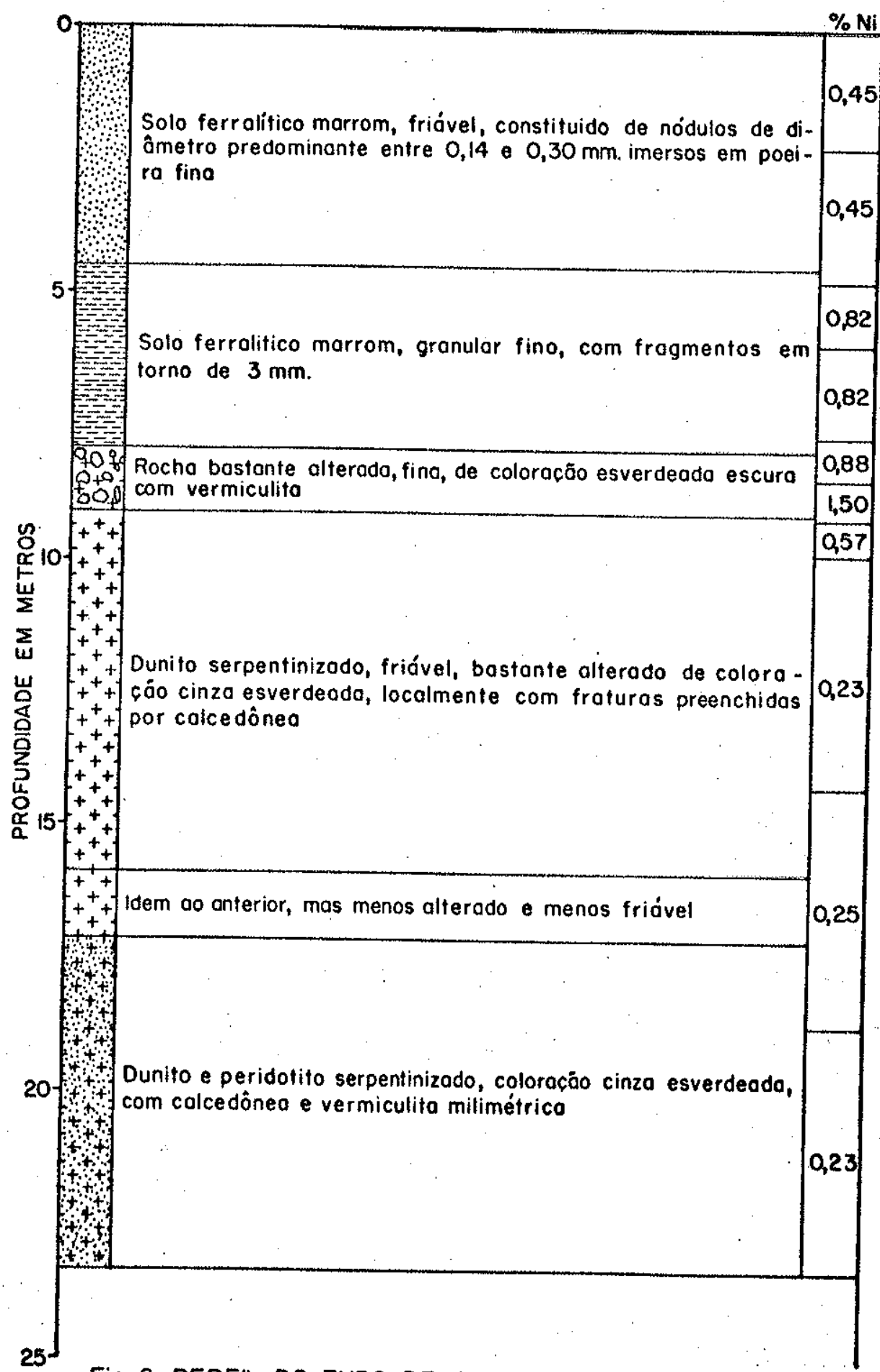

Fig. 6-PERFIL DO FURO DE SONDAGEM N2 18, N10 +50 E7 EM AREA DE DUNITO E PERIDOTITO 
VII.I.I-GNAISSES

Os gnaisses apresentam variações em sua composição, desde leuco atē melanocrāticos, localmente com cavidades for radas de cristais grosseiros de feldspato, evidência da ação de soluções metassomäticas. Alēm da variação na composição mineralögica, o grau de cataclase tambēm varia de amostra pa ra amostra em um extremo, com ultramilonitos, dassando por fases intermediärias de milonitização, textura em moldura (Foto 3), encurvamento das lamelas de plagioclásio, extinção on dulante do quartzo e fragmentação, chegando, no outro extremo, a uma cataclase restrita e incipiente. Em uma faixa peri fërica ā zona de contato do maciço, nas regiões $S$, SE e $S W$, a textura cataclāstica è comum, evidenciando, com a miloniti zação, a fragmentação generalizada das rochas no processo de intrusão do maciço.

Em ordem quantitativa decrescente, esses gnaisses compōem-se de feldspato potässico, plagiocläsio, quartzo,mica e acessōrios. Estes são representados pela apatita e opacos. A porcentagem de biotita (mais comum) ou muscovita $\bar{e}$ bastante variāvel.

A estrutura bandada ou paralela $\bar{e}$ evidenciada pela orientação da mica e alternāncia de bandas dos minerais cita dos acima.

\section{VII.I.2 - HORNBLENDA GNAISSE}

Rocha formada no contato da ultramäfica com o gnais se. Pela localização e composição deve ter se formado por me tassomatismo. Essa rocha estā sendo descrita em separado,pe- 


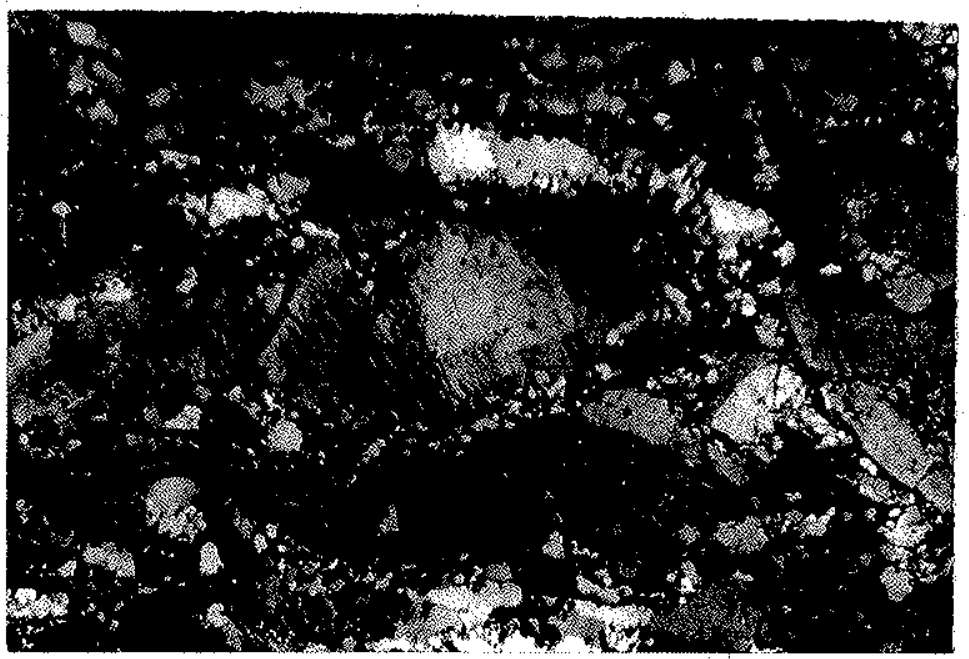

Foto 3 - Gnaisse milonitizado com textura em moldura. Massa constituida de quartzo e feldspato. Aumento $20 \mathrm{X}$; $\mathrm{Nicöis} \mathrm{semi-cruzados.}$

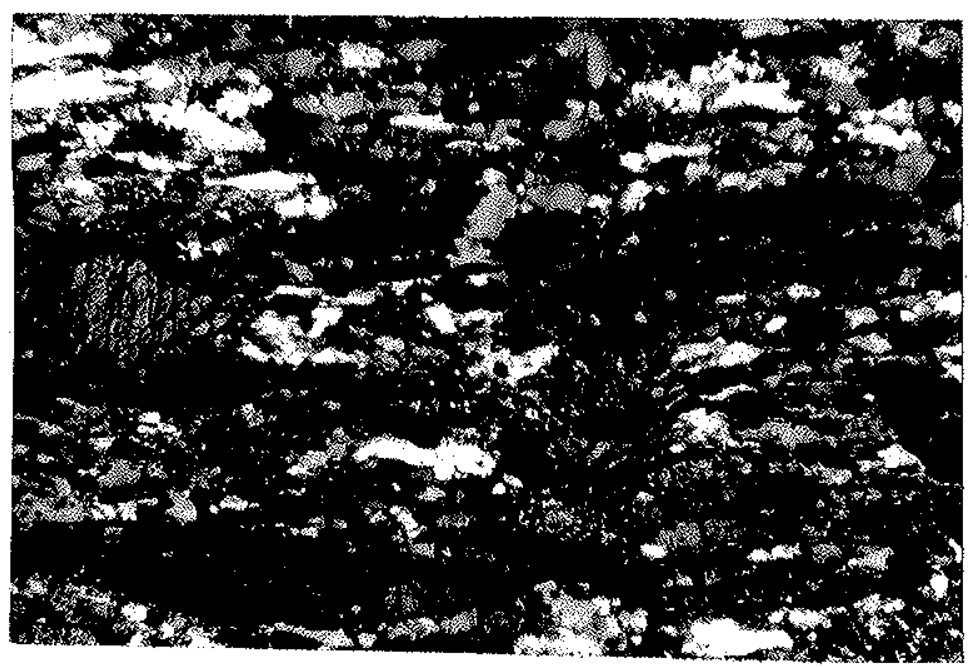

Foto 4 - Furo 8 - Profundidade de 36 " m. Hornblenda gnaisse com sinais de cataclase. Massa fragmentada de quartzo e feldspato. Porfiroblasto de hornblenda. Nicóis cruzados. Aumento $20 x$. 
10 fato de ocorrer em āreas mapeāveis do contato e ter sido encontrada em vārios pontos do distrito, como mostra o mapa da Figura 3. Sua constituição mineralógica, em ordem quantitativa decrescente, ē a seguinte: hornblenda, feldspato potāssico, plagioclāsio, biotita, quartzo, granada e epidoto. A hornblenda apresenta-se em grandes cristais englobando outros minerais e pode se alterar para biotita, como tambēm mi nerais opacos. Epidoto e granada foram vistos em pequena quantidade em algumas lâminas.

Localmente essa rocha ē bandada, com alternāncia de bandas claras, com quartzo, feldspato potāssico e plagioclāsio, e escuras, com hornblenda, biotita e epidoto. Textura cataclāstica é visivel em muitas amostras (Foto 4).Essa textura deve ter facilitado a ação de soluções hidrotermais, res ponsāveis pela formação de cristais grosseiros de epidoto. As melhores amostras para estudo microscópico provêm dos furos de sonda $\mathrm{Fl}, \mathrm{F} 7, \mathrm{~F} 8$ e $\mathrm{F} 68$, coletadas em profundidade de algumas dezenas de metros. Amostras superficiais foram coletadas em alguns contatos do maciço, quase todas com um certo grau de alteração.

VII.1.3 - IDENTIFICAÇÃO DOS DUNITOS;PERIDOTITOS E PIROXENITOS NO CAMPO

Estas rochas foram identificadas atravēs de lâminas delgadas e foram coletadas de escassos afloramentos bastante alterados e de furos de sonda. Foram consideradas como dunitos rochas portadoras de, no mínimo, $90 \%$ de olivina. Evitando-se toda a discussão terminolōgica criada em torno do ter mo: peridotito, foi considerada a classificação de HYNDMAN (1972) que coloca os limites de 30 e $90 \%$ de olivina para este grupo. Finalmente, os piroxenitos, segundo a mesma class 
ficação, limitam a $30 \%$ a olivina, contendo basicamente piroxẽnios.

0 mapeamento das rochas do distrito $\bar{e}$ dificuitado pela presença de uma capa de alteração constituída de solo ferralitico solto, de cor marrom. As rochas apenas afloram quando "emergem" desta capa nas encostas dos morros ou em pe quenas elevações. Este obstäculo foi superado pela descrição e comparação dos perfis de poços perfurados no distrito, de modo a permitir a identificação da rocha pelo seu produto de alteração, logo abaixo do solo ferralítico amarelo. Assim a partir do saprölito fino, localizado abaixo do solo ferralítico amarelo, atē o fundo do poço, foram estudadas as vārias caracteristicas da rocha alterada, entre elas a coloração, granulação (agregação), estrutura e, quando necessārio, os teores de $\mathrm{Ni}$.

A avaliação quantitativa da olivina na rocha altera da pode ser feita com certa facilidade pela porcentagem de manchas ferruginosas marrons formadas pela alteração deste mineral. Do solo ferralitico amarelo para cima e praticamente impossível identificar a rocha subjacente.

As Fotos coloridas de nümeros $5,6,7,8$ e 9 dão uma idēia do perfil do solo e as diferenças dos produtos de alteração formados a partir de dunitos, peridotitos e piroxe nitos. A cor e o estado de agregação são os fatores físicos mais distintos na identificação destes três tipos de rochas. Este tipo de identificação foi utilizado pelos geōlogos da Companhia Montita de Mineração, resultando,nas condições 10cais de alteração, um mapa de distribuição das rochas com razoāvel precisão. A distribuição dos dunitos,peridotitos e piroxenitos foi confirmada verificando-se os teores médios de $\mathrm{Ni}$ em cada um dos poços amostrados e analisados. 


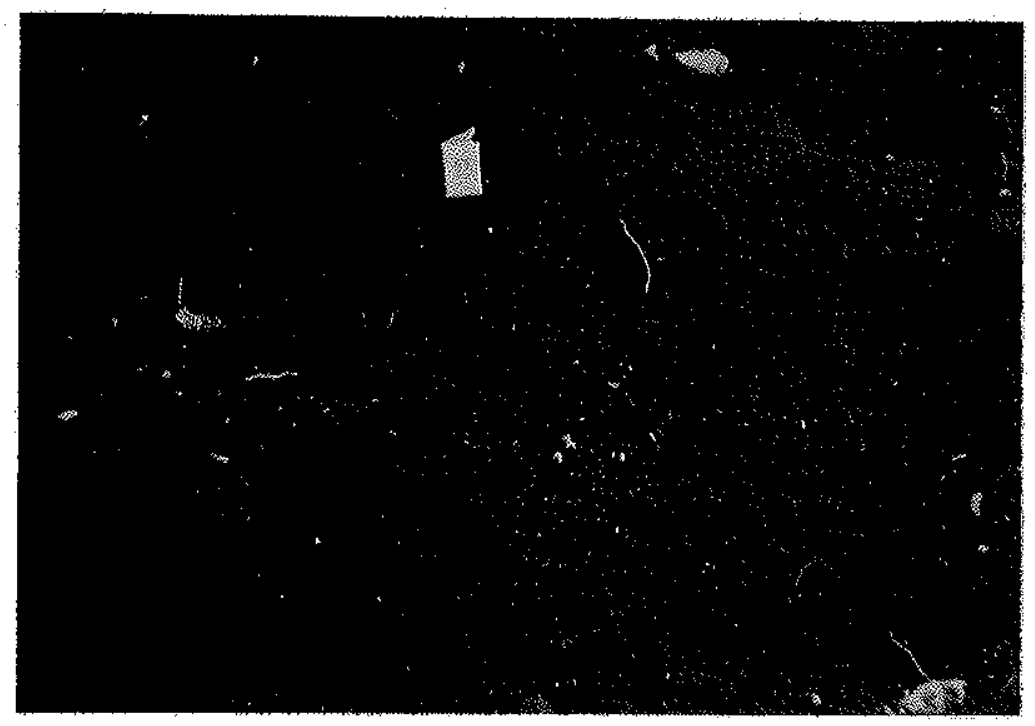

Foto 5 - Solo ferralitico marrom constituindo um manto sobre as zonas planas e baixas do distrito. Desaparece nas encostas suaves dos morros ou em pequenas elevações.

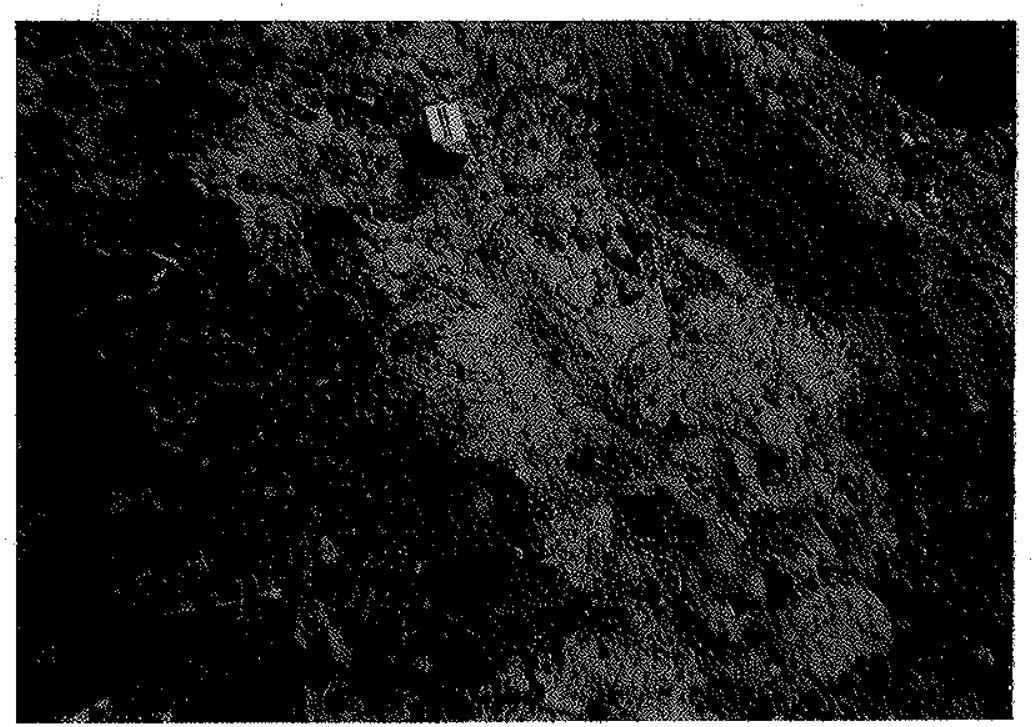

Foto 6 - Solo ferralitico amarelo que se forma sobre piroxenito, peridotito ou dunito, sendo mais espesso e ri co em $\mathrm{Ni}$ sobre esta última rocha. 


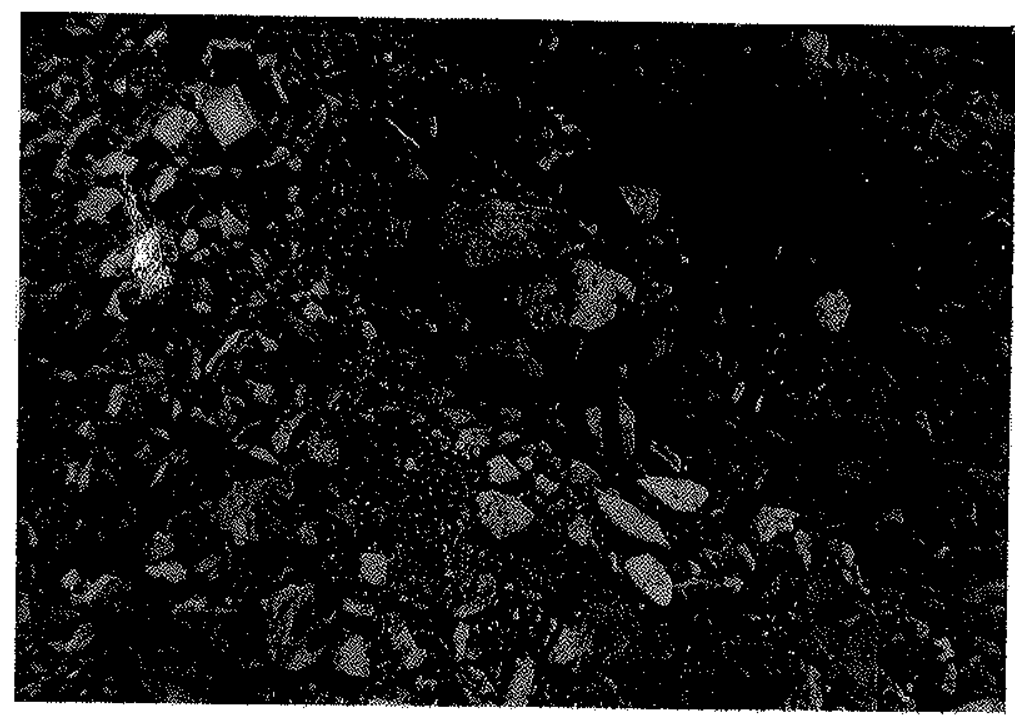

Foto 7 - Dunito alterado, cor verde escura com manchas marrons. Fragmentos grosseiros predominantes. Alto teor de $\mathrm{Ni}$.

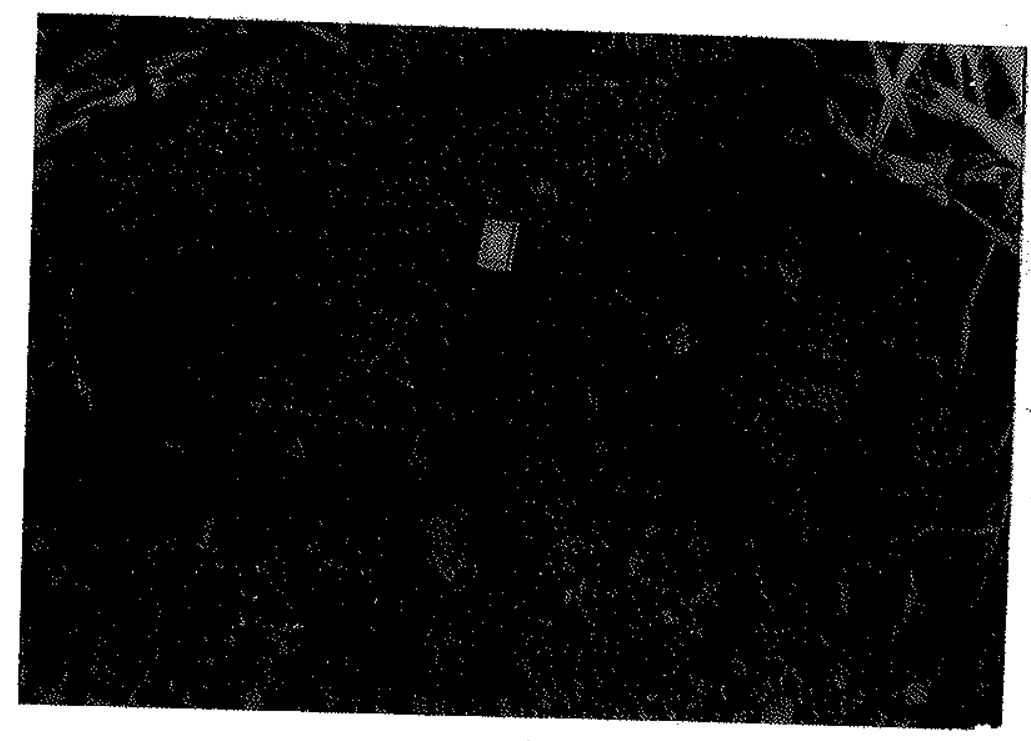

Foto 8 - Peridotito serpentinizado alterado. Cor verde mais clara, maior porcentagem de finos e teor de Ni inferior em comparação ao dos dunitos. 


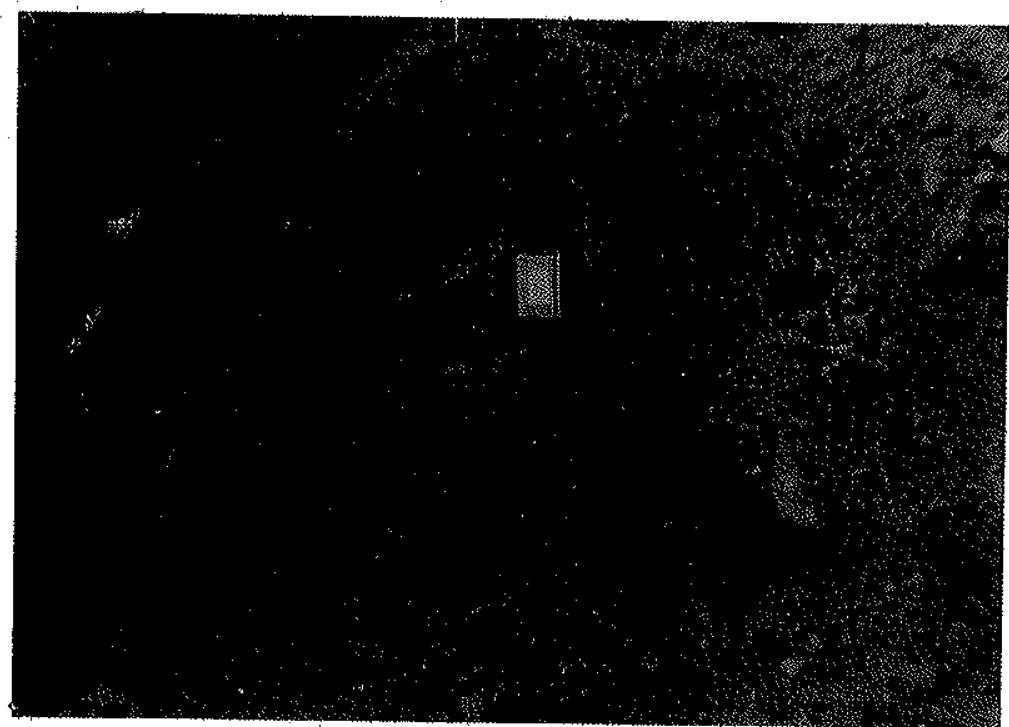

Foto 9 - Piroxenito alterado constituindo material predominantemente fino, cor verde clara, às vezes amarela da. Os teores de $\mathrm{Ni}$ são baixos.

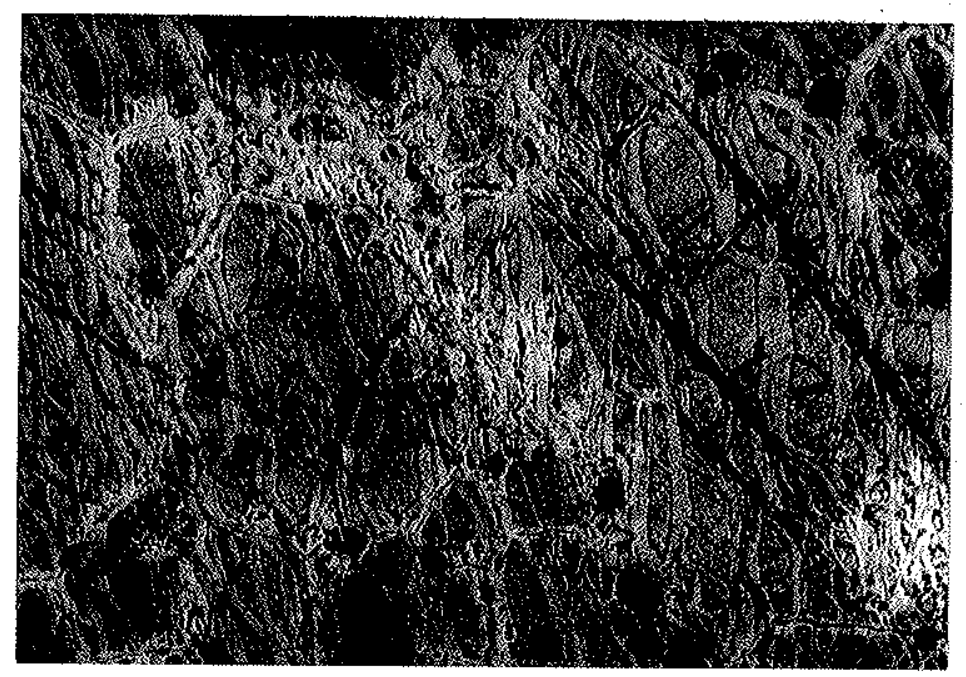

Foto 10 - Furo 27 - Profundidade de $6,3 \mathrm{~m}$. Dunito parcialmente serpentinizado, com relictos de olivina opacos - Nicóis descruzados. Aumento $20 \mathrm{X}$. 
0 solo ferralitico marrom e amarelo, assim como os três tipos de rochas ultramäficas, acham-se representados em cada uma das cinco fotos coloridas anexadas ao capitulo.

$$
\text { VII.1.4- DUNITOS }
$$

Sob este titulo consideraremos a rocha que originou os serpentinitos e que ocupa $80 \%$ da ārea superficial do distrito. Sua importāncia, então, ē ōbvia, pela representatividade geogräfica e por ser a rocha original portadora de níque 1 .

Os dunitos ocupam o centro do maciço e estão envolvidos por peridotitos e piroxenitos (Figura 3). São rochas de coloração verde escura, esmaecendo para verde-amarelado quando sujeitas à intempērie superficial em topos ou encostas de morros. A granulação ē fina a mēdia, sendo constituĩda predominantemente de olivina magnesiana (mais de 90\%), algum clinopiroxēnio, minerais opacos dispersos (magnetita, cromita, ilmenita) e uma pequena porcentagem de biotita e flogopi ta. A alteração da olivina leva à formação de minerais ferrú ginosos (magnetita, goethita) que são adicionados aos opacos originais da rocha. Tanto em profundidade quanto na superficie, os dunitos acham-se serpentinizados em maior ou menor intensidade, identificando-se com facilidade os relictos de olivina (Foto no 10).

Foram caracterizadas, no mínimo, duas intrusões com base na textura, traços tectōnicos locais e morfologia, alēm de outras características evidenciadas no campo e no estudo das lâminas de rochas. Assim, distinguiu-se na zona do Tirapressa, ao sul do distrito, dunitos com teores originais de 
$\mathrm{Ni}$ mais baixos, possivelmente introduzidos no maciço posteriormente. Correspondem a uma zona onde são mais ferruginosos, formam rochas com relevo mais alto e com um sistema dis tinto de fraturas e falhas de direção NW e NE. A textura dos dunitos alterados parece favorecer a formação de um saprōlito mais grosseiro, agregando com mais facilidade os cristais de olivina alterados. A ausēncia de furos de sonda mais profundos não permite avaliar se se trata de uma zona de serpen tinização maior ou menor. O "deficit" original de Ni tambēm não auxilia, pois, segundo FAUST et al. (1956), a serpentini zação não altera a porcentagem original deste elemento.

A zona rasa, plana, com morros isolados ao leste, oeste e norte do distrito (Foto nọ 1), deve corresponder a uma faixa mais antiga, originariamente mais rica em Ni. Embo ra contendo apenas morros testemunhos, quase todos constituí dos de dunitos, nota-se que os traços tectōnicos não são prọe minentes como aqueles descritos anteriormente.

A passagem dos dunitos para peridotitos na zona pe riférica é gradual, como consequéncia do aumento paulatino da porcentagem de clino-piroxênio cālcico. os contatos po dem ser mais bruscos, dependendo da ārea considerada.

\section{VII.1.5- PERIDOTITOS}

$0 \mathrm{~s}$ peridotitos constituem um anel descontinuo e ir regular distribuido em torno dos dunitos e que tem expressão superficial na forma de lentes, faixas ou camadas. Esta dis tribuição é coerente com o fato observado de que as rochas do maciço gradam de uma zona olivínica central até uma zona piroxeñ̄tica perifērica, passando por uma zona intermediāria 
de rochas peridotîticas. Esta distribuição deve ser espa cial. Localmente, a passagem de uma rocha para outra pode ser brusca, como atestam contatos diretos entre dunitos e piroxenitos. Estes contatos bruscos talvez pudessem, em parte, ser explicados por descontinuidades de contato de duas ou mais intrusões.

Os peridotitos têm granulação submilimētrica e são constituídos essencialmente de olivina e piroxênios (Foto no 11). Feldspatóides, biotita ou opacos ocorrem como aces sōrios em algumas amostras. Os piroxênios estão represen tados predominantemente por augita-diopsídio e dialāgio. os produtos de alteração secundāria dependem da porcentagem de olivina da rocha original. São friāveis quando pobres de olivina e mais grosseiros e coesos quando hā predominância desse mineral.

\section{VII.I.6 - PIROXENITOS}

Rocha de granulação mēdia a grossa, cor cinza escu ra, constituída de augita, olivina, alguma biotita e opacos. Sua distribuição assemelha-se, grosso modo, àquela dos peridotitos, com a diferença, visível no mapa da Figu ra no 3, de sua maior continuidade horizontal e, provavel mente, vertical. E mais representativa em ārea no distrito do que os peridotitos, avizinhando-se, na parte externa do maciço,das encaixantes.

Em escala microscōpica e local, cristais de piroxê nio podem ser serpentinizados. 0s piroxenitos alterados formam material pulverulento de coloração verde clara, con trastando, devido a sua grande friabilidade, com as rochas 


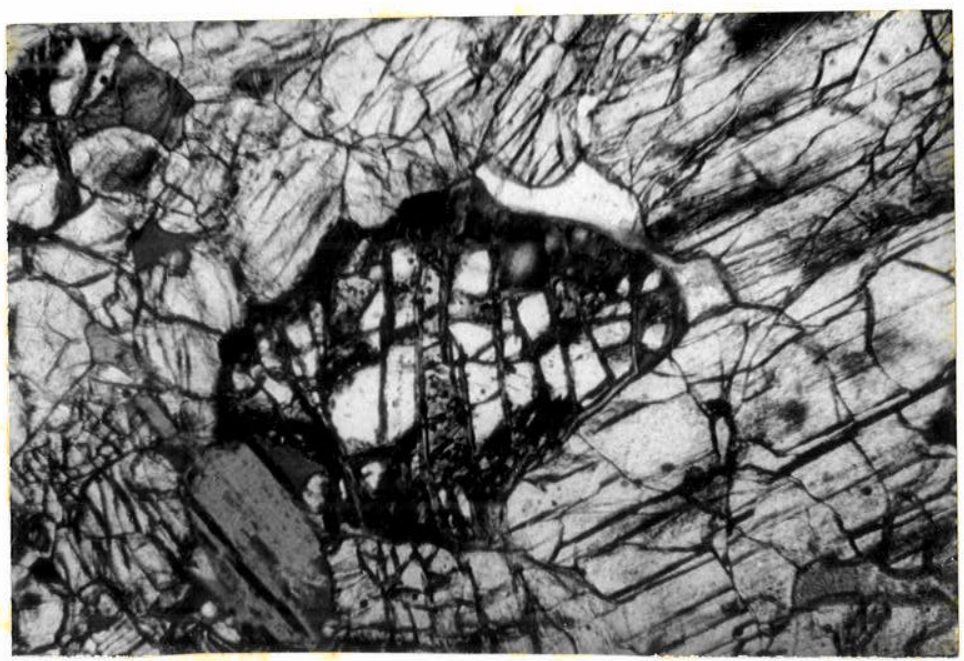

Foto 11 - Furo 1 - Profundidade de 61 m. Peridotito com cris tal de olivina parcialmente serpentinizado. Piroxe nio predominante, com agulhas finissimas de ruti1o(?). Biotita e opacos. Nicóis descruzados. Aumen to $20 \mathrm{X}$.

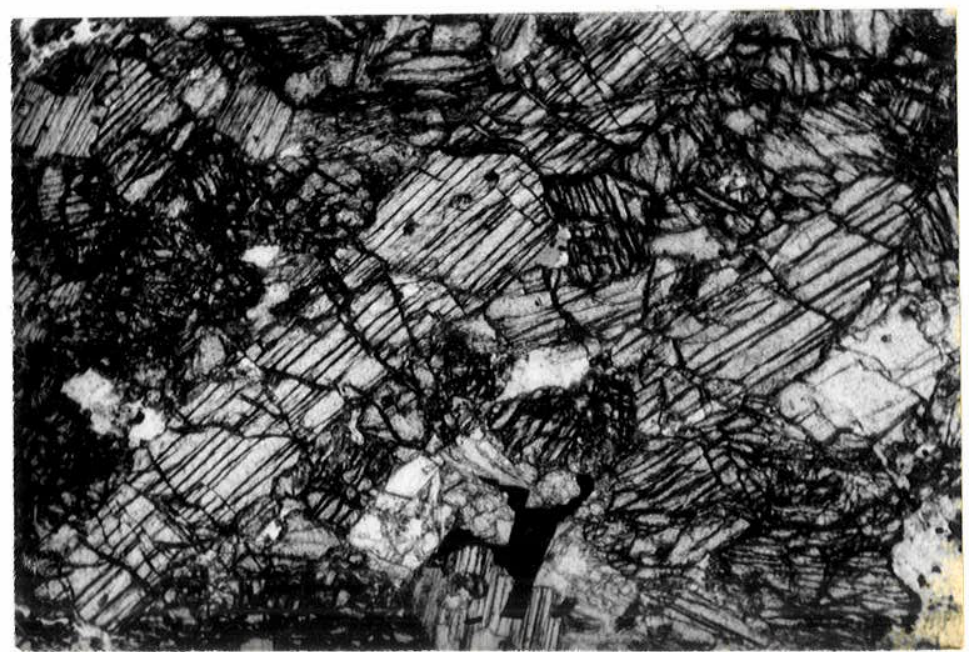

Foto 12 - Furo 6 - Profundidade de 47,5 m. Piroxenito opacos. Nicóis descruzados. Aumento $20 \mathrm{X}$. 
alteradas portadoras de olivina.

$$
\text { VII.I.7 - MISSOURITO }
$$

Rocha pertencente $\bar{a}$ clã dos gabros alcalinos. Cons titui um pequeno afloramento na região centro norte do dis trito, mas, como descrito por LESSA SOBRINHO et al. (1971), não foi localizada na ārea sul. Apresenta granulação média e, em sua composição, confirma a mineralogia descrita pelos autores acima citados, contendo: piroxēnio do tipo diopsídio-augita, olivina, leucita e biotita. Apatita e opacos são os acessōrios mais comuns. Da alteração dos minerais acima pode-se formar sericita e clorita.

$$
\text { VII.I.8 - MALIGNITOS }
$$

Gabro alcalino que ocorre em uma restrita e peque na ārea ao sul do distrito. Tem granulação submilimētrica e $\bar{e}$ constituído de nefelina, ortoclāsio, diopsídio-augita, bio tita, opacos e apatita. A nefelina e a apatita estão inter crescidas em textura poiquilītica no ortoclāsio. Parte des tes minerais è vista na Foto nọ 14.

Esta rocha foi mencionada e descrita em relatōrio anterior não publicado. 


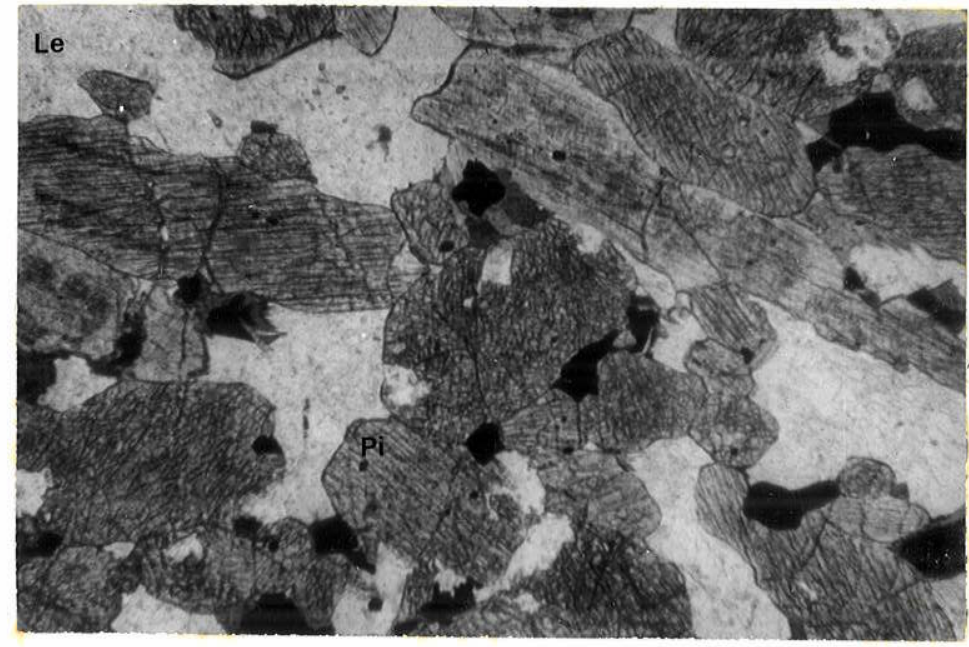

Foto 13 - Missourito, com piroxēnio (Pi) predominante, leucita (Le) e opacos. Nicóis descruzados. Aumento $20 \mathrm{x}$.

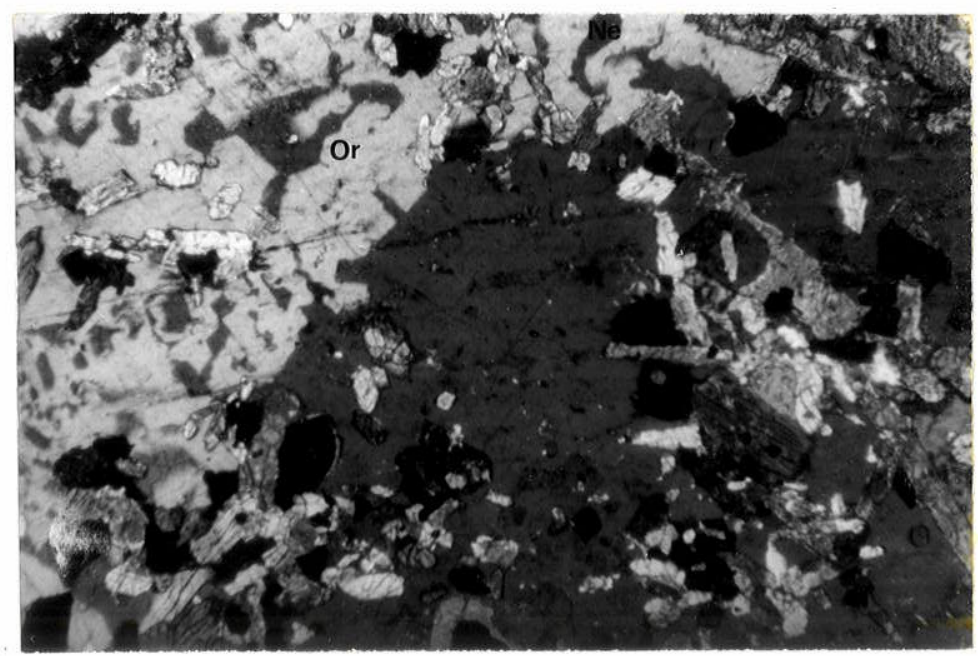

Foto 14 - Malignito - Textura poiquilitica mostrando fenocristais de ortoclásio (or) englobando nefelina (Ne), piroxēnio, biotita e opacos. Nicóis semicruzados - Aumento $20 \mathrm{X}$. 


\section{VII.1.9 - SERPENTINITOS}

Trata-se da litologia mais representativa no trito. Apresenta coloração verde escura a verde clara,

dis coesa e localmente friāvel. Formou-se pela serpentinização a partir de dunitos e, em āreas mais restritas, a partir de peridotitos.

Estudos petrogrāficos em lâminas delgadas indicam que os serpentinitos do distrito sempre apresentam vestigios de olivina, mesmo quando em estādios avançados de alteração secundāria. Localmente, os grãos reliquiares de olivina po dem ser identificados pelo material ferruginoso formado ao seu redor. Tambēm em lâminas delgadas foi observada serpen tinização de piroxênios, mas apenas em escala reduzida, sem constituir um fenômeno representativo no distrito.

Três polimorfos constituem as serpentinas de Santa Fé: lizardita, crisotila e antigorita. Como a identificação destes polimorfos por meios ópticos não é segura, foram fẹ tas anālises termo-diferenciais de amostras que foram dividi das em quatro frações granulométricas:

$$
\begin{array}{llll}
\text { Acima de } 0,50 \mathrm{~mm} & \text { - Amostra } n ! & 1 \\
\text { Entre } 0,50-0,35 \mathrm{~mm} & \text { - Amostra } n ! & 2 \\
\text { Entre } 0,35-0,12 \mathrm{~mm} & \text { - Amostra } n ! 3 & 3 \\
\text { Abaixo de } 0,12 \mathrm{~mm} & \text { - Amostra } n ! 4
\end{array}
$$

Da observação da Figura nọ 7, que contēm os resul tados das anālises termo diferenciais das quatro amostras acima, nota-se que a granulação não afetou a intensidade e/ lou posição dos picos.

De acordo com ZEISSINK (1969), FAUST \& FAHEY (1962) 
Fig. 7-ANÁLISE TERMO DIFERENCIAL DA ULTRAMÁFICA SERPENTINIZADA

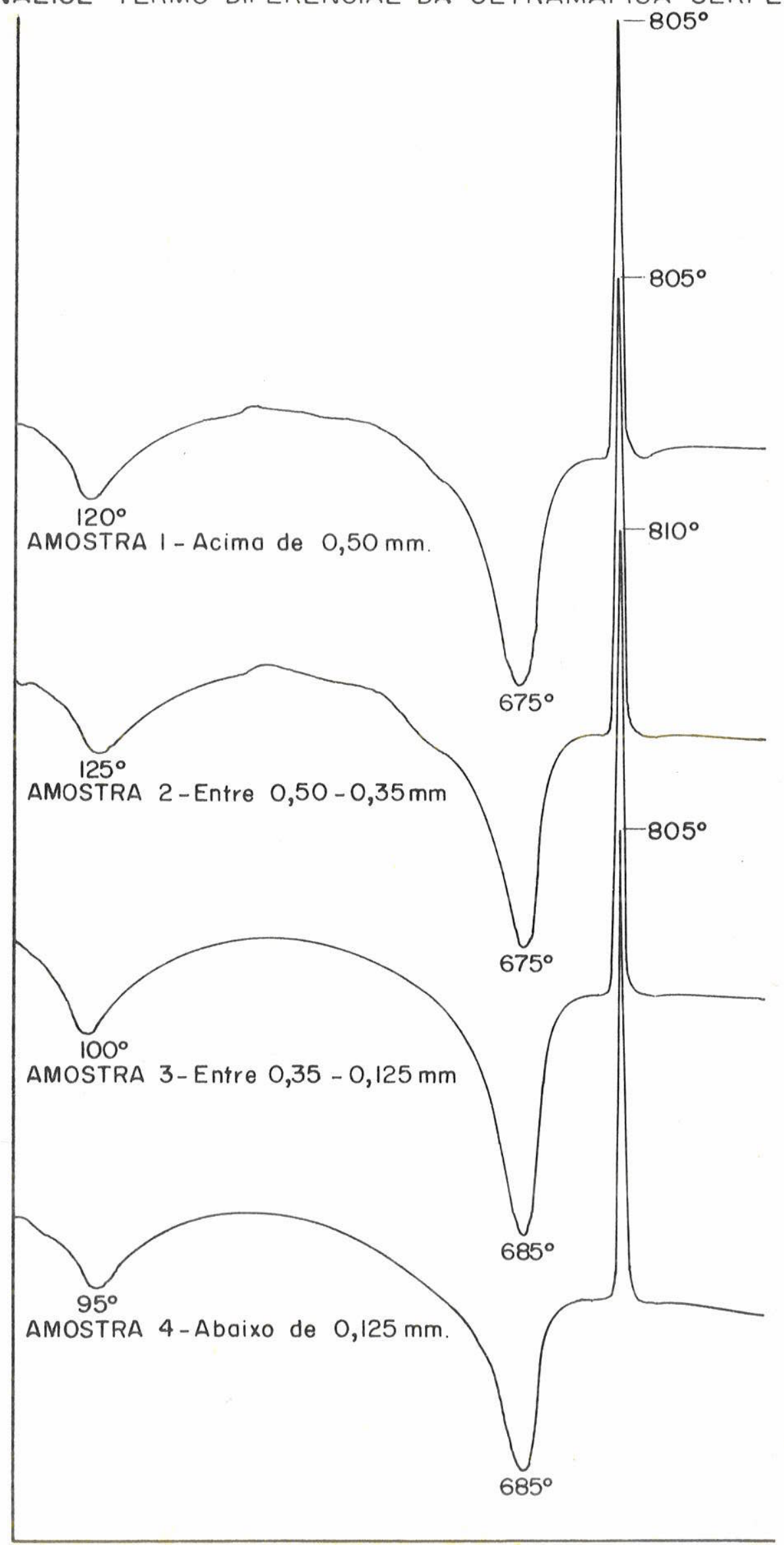


mostraram que as curvas de ATD podem ser aplicadas para de tectar antigorita e o par não diferenciāvel crisotila-lizar dita. O mínimo do pico endotērmico para antigorita cai na variação $790^{\circ}-802^{\circ} \mathrm{C}$. Para crisotila e lizardita este mí nimo ocorre entre 637 e $795^{\circ} \mathrm{C}$. Em adição, para o par crisó tila-lizardita, um pico exotērmico estā presente, 83 a $145^{\circ} \mathrm{C}$ acima da temperatura do pico endotērmico. A Figura nọ 7 in dica que as amostras analisadas são de crisotila-lizardita. DEER, HOWIE \& ZUSSMAN (1962, p. 185), afirmam que "crisotila- lizardita tem um pico endotérmico entre 680 e $750^{\circ} \mathrm{C}$, apre sentando, em seguida, um pico exotérmico com a formação dé olivina, entre 800 e $820^{\circ}$ C". Ainda segundo estes autores, um pico fraco e largo de baixa temperatura pode ocorrer se houver expulsão de āgua.

Em quantidade menor, podem ocorrer nos serpentini tos, flogopita, vermiculita, biotita e clorita, assim comó calcedōnea e carbonatos.

0 grau de serpentinização dos serpentinitos è va riāvel com a profundidade. Na Figura nọ 8 nota-se um lige ro, mas, progressivo aumento da porcentagem de olivina ser pentinizada com a profundidade. E evidente a variação brus ca da porcentagem de serpentinização de um ponto para outro, fato este devido ao fraturamento local maior ou menor da uI tramāfica que facilitou o acesso dos agentes de alteração. 0 grāfico é resultado da contagem de pontos de setenta e três lâminas delgadas de amostras coletadas ao longo do furo de sondagem no 27 localizado em dunito. As Fotos nrs. 15 e 16 mostram dunito superficial pouco serpentinizado e mais pro fundo $(78,9 \mathrm{~m})$ com acentuada serpentinização.

Serpentinização tem sido definida em numerosas pesquisas como um fenōmeno provocado por soluções ascenden tes, em temperaturas acentuadamente elevadas em relação ä 


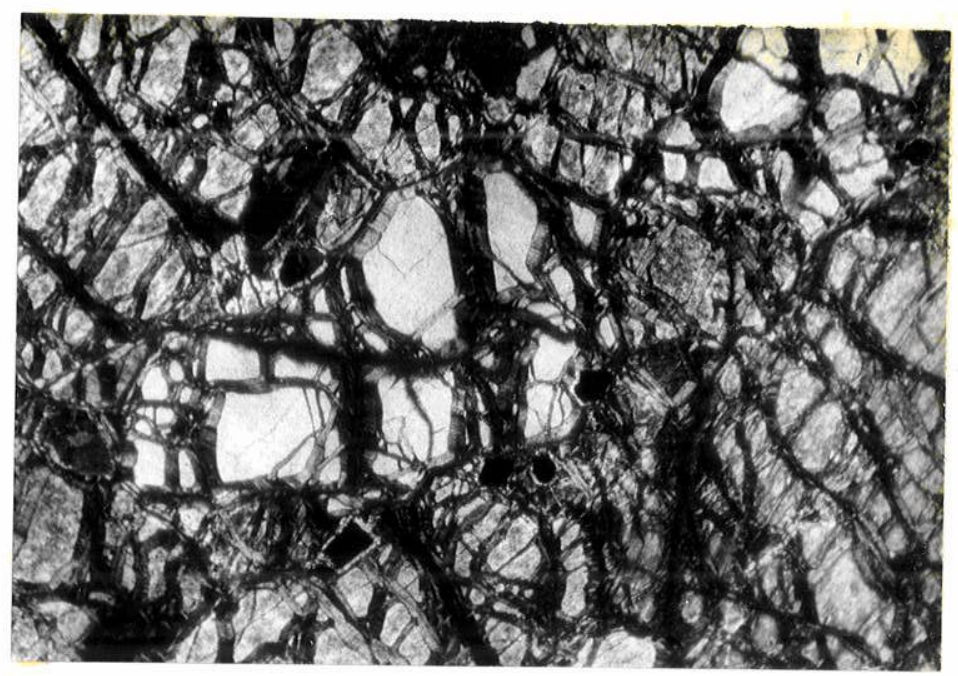

Foto 15 - Furo 27 - Profundidade de 5,8 m. Dunito pouco ser - Aumento 20 X.

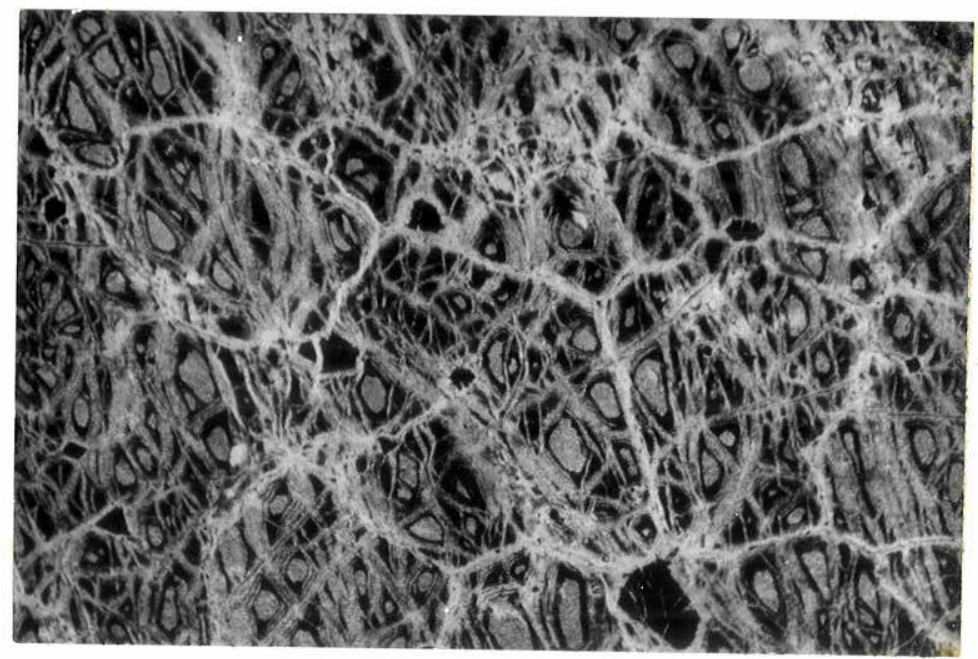

Foto 16 - Furo 27 - Profundidade de 78,9 m - Serpentinização acentuada por processo ascendente. Relictos de $01 i$ vina - Nicóis descruzados. Aumento $20 \mathrm{X}$. 
ambiente. Entre estas pesquisas merece menção BOWEN \& TUTTLE (1949), SCARFE \& WILLIE (1967) e JOHANNES (1968). Em contra posição, BARNES \& O'NEIL (1969) observaram que este fenōmeno pode ser provocado por agentes intempëricos superficiais, em temperaturas prōximas da ambiente.

No gräfico anexo observa-se que o maior grau de serpentinização em profundidade parece indicar um processo hipōgeno ascendente. Alēm disto, nota-se a maior porcenta gem de opacos em profundidade, decorrente do processo simul tâneo de serpentinização e liberação de ferro para a forma ção de opacos (magnetita, goethita, etc.). E tambēm eviden te a maior homogeneidade no grau de serpentinização das lâmi nas coletadas em profundidades mais rasas, sugerindo a atua ção dos agentes intempéricos descendentes. Resta mencionar que, mesmo amostras bem próximas da superfície não são total mente serpentinizadas, dada à existēncia de nūcleos de oliví na nos grãos de serpentina.

Os serpentinitos localizados em encostas de morros, submetidos aos processos meteōricos superficiais, têm uma textura mais grosseira devido à agregação dos relictos de olivina. Conforme aumenta a profundidade, o serpentinito torna-se menos agregado e de textura mais fina, mas ainda sob ação de fenōmenos intempēricos descendentes. Apōs uma certa profundidade, praticamente inacessivel aos processos intempēricos descendentes, o serpentinito adquire cor verde mais escura, torna-se menos poroso e o sistema de microfratu ras deixa de ser visivel, reduzindo-se substancialmente a porcentagem de calcedōnea.

Todos estes fatos nos levam a admitir inicialmente um processo de serpentinização hipögeno ascendente, seguido de serpentinização superficial secundāria.

Aumento de grau de serpentinização com a profundị 
dade foi observado nos maciços de Barro Alto e de Tocantins, Goiās, segundo FIGUEIREDO et al. (1975).

Merece menção neste capítulo, sem contudo consti tuir um item à parte, a presença no distrito de faixas de al teração hidrotermal com dimensões máximas de alguns metros de espessura e pouco mais de duas dezenas de metros de com primento. Seu aparecimento nas zonas onde veios de vermicú lita são comuns empresta um significado genético comum a am bos. Observa-se que algumas dessas zonas de alteração coñ tēm, em sua ārea central, veios de vermiculita. Alēm dissó, nota-se que a quantidade de opacos é maior nas proximidades imediatas dessas zonas. Um estudo mais pormenorizado de amostras de poços e trincheiras mostrou grande quantidade de talco e carbonato constituindo uma massa de cor esbranquiça da com uma certa quantidade de minerais opacos dispersos (Fo to no 17). Ao microscōpio, foi identificada perowskita, em fenocristais, e apatita. A perowskita, estudada tambēm em seções polidas, quando associada a agregados de minerais opa cos, mostra cristais idiomōrficos de cor cinza escura, com reflexões internas amareladas e intensas. Micrografia ele trōnica e anālises para Ca, Ti, Fe, Mg, Si e Nb em microsson da (Foto no 18), constataram tambēm a presença de magnetita e ilmenita. Restos de uma rocha olivínica com algum clinopi roxênio foram notados. Evidências de quebramento e miloniti zação são comuns, visíveis na rocha dunitica encaixante. Em se tratando de alteração hidrotermal, as evidências cataclās ticas, assim como a paragēnese mineralōgica, são prōprias e indicativas desse fenōmeno. 


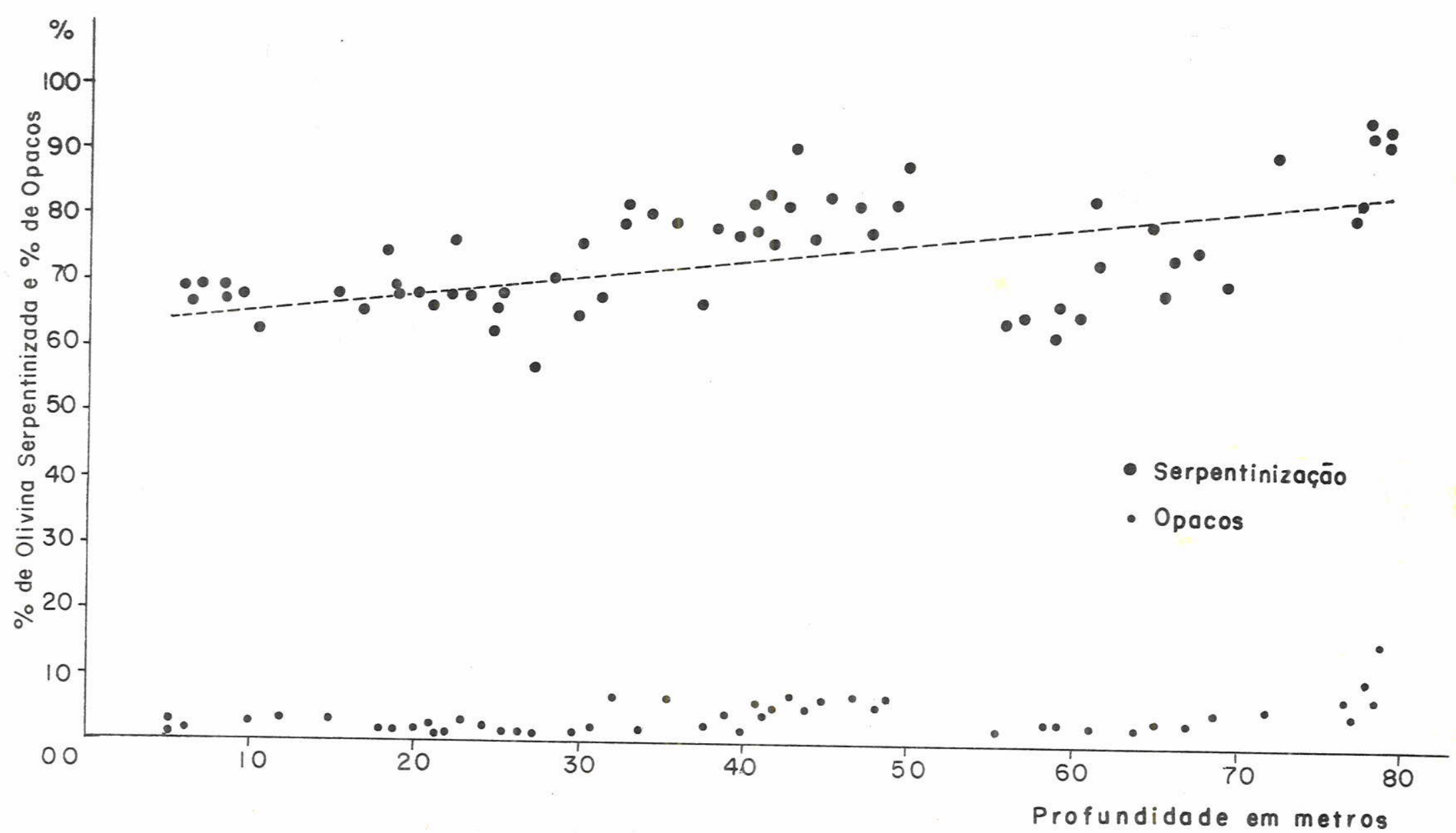

Fig. 8-SERPENTINIZAÇÃO DE DUNITO DE ACORDO COM PROFUNDIDADE AMOSTRAS COLETADAS NO FURO DE SONDA F-27 


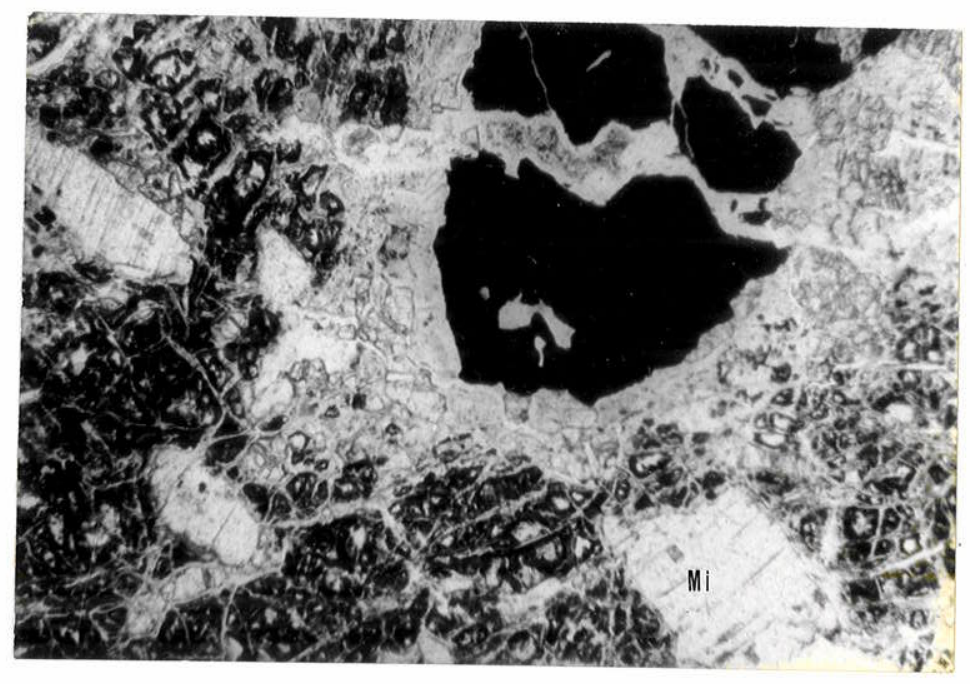

Foto 17 - Lãmina delgada de zona de altera ção hidroterma 1. Perowskita escu ra envolvida por magnesita cinza clara,olivina serpentinizada cin za escura com opacos e cristais de mica (Mi) - Nicóis descruzados. Aumento $20 \mathrm{X}$. 


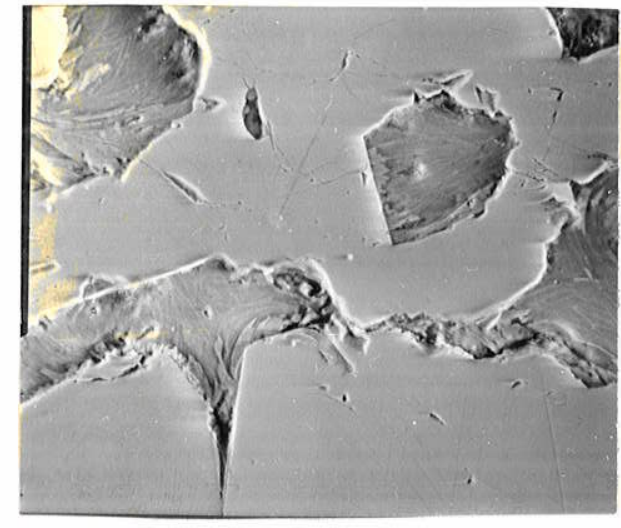

Seção A-1 - Comp. 400 X

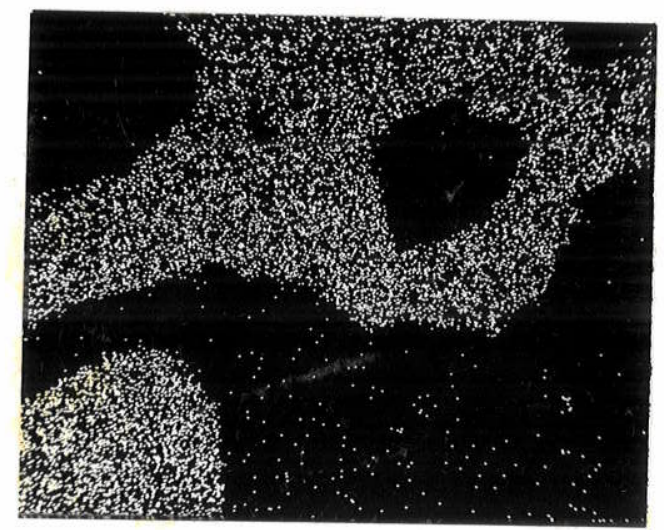

Seção $A-3 ; \quad T i(K \alpha)$

Cristais de perowskita e ilmenita

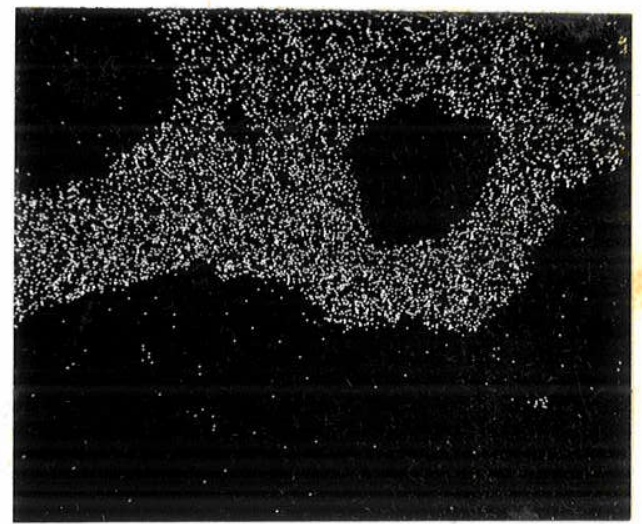

Seção A-2; Ca $(K \alpha)$

Cristal de perowskita

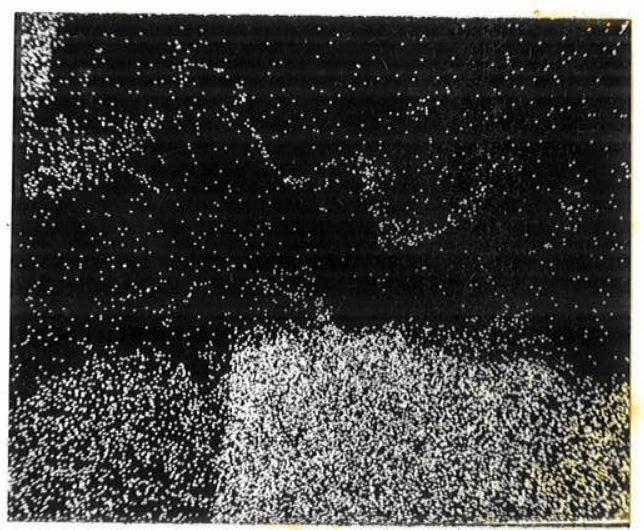

Seção A-4; $\mathrm{Fe}(K \alpha)$

Cristais de magnetita e ilme nita 


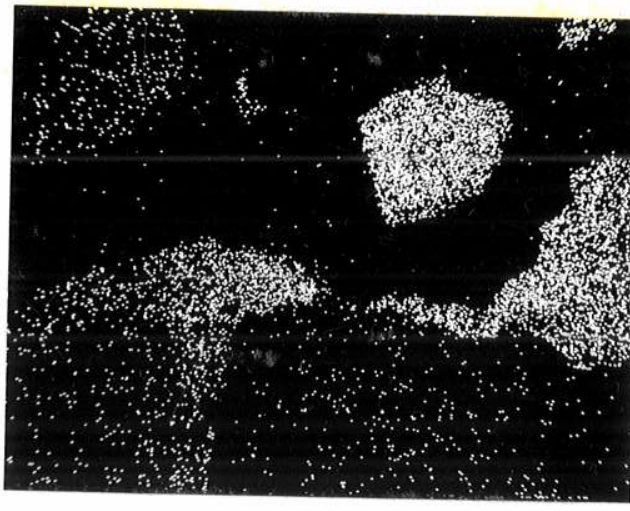

Seção $A-5 ; M g(K \alpha)$

Seção A-6; Si $(K \alpha)$
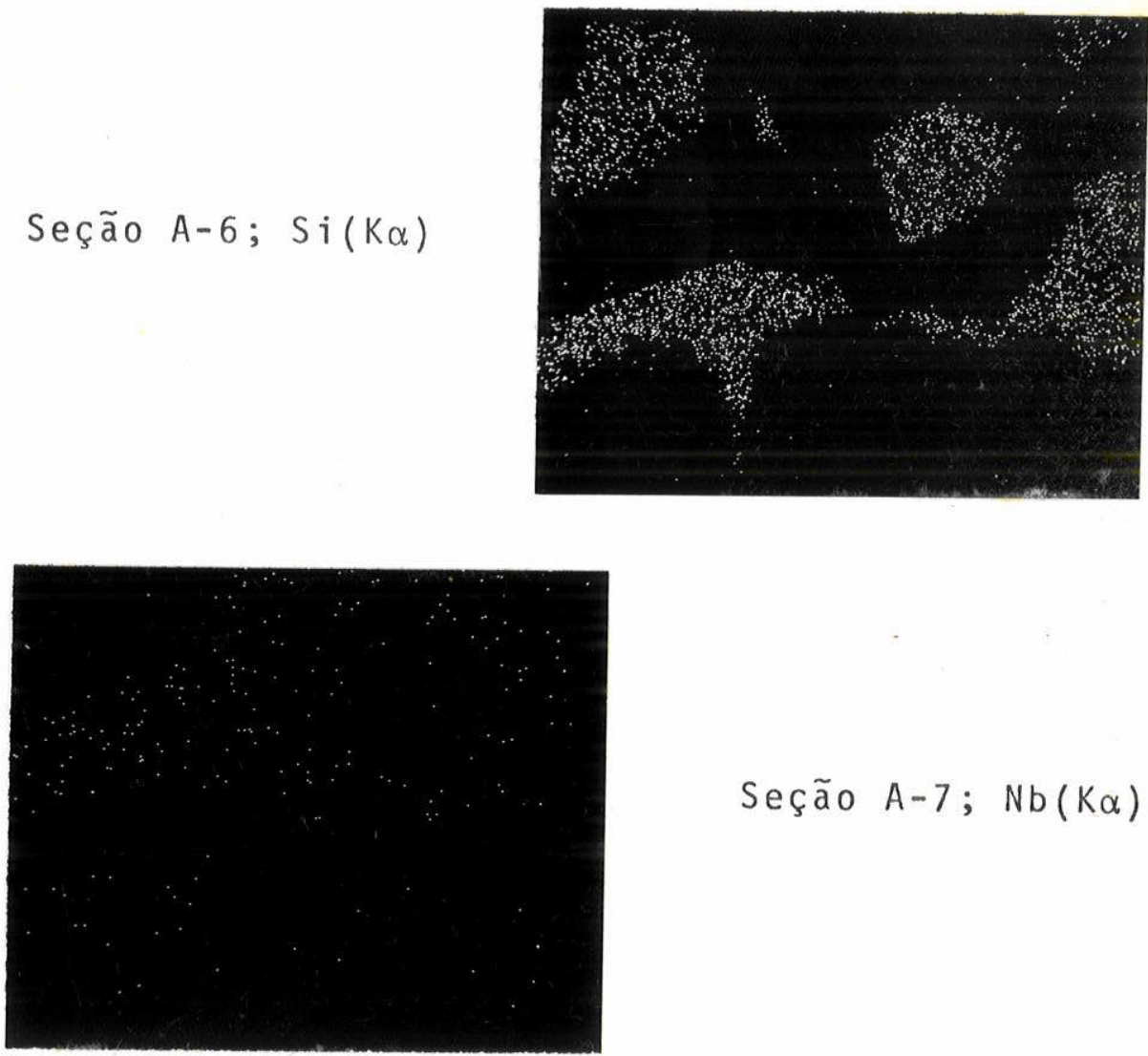

Seção A-7; Nb $(K \alpha)$

Foto 18 - Seções A-1 a A-7 - Micrografia eletrōnica e microssonda de seção polida de zona de alteração hidroterma 1. Perowskita rica em Ca, Ti e algum $\mathrm{Nb}$; magnetita rica em Fe e ilmenita rica em Ti. 
VII. 2 - TRAÇOS ESTRUTURAIS

0 complexo ultramäfico de Santa Fē tem forma oval, com o eixo maior na direção $N-S$. Observações de campo assim como de fotografias aēreas indicam que um sistema de fratu ras paralelas ressalta os contatos externos de parte do com plexo.

A estrutura dômica do maciço não é visĩvel pela mor fologia local, mas pode ser inferida da observação da sequen cia litológica dos furos de sonda locados na borda $E$ e $W$ do mesmo (Figura 4). Nesta ūitima borda observa-se que:

dade, a dunito.

0 furo de sonda F-35 (Ārea VI) passa, em profundi

0 furo de sonda F-33 (Ärea VI) é constituĩdo de du nito em toda sua extensão, como tambēm os furos de sonda F-34 e $\mathrm{F}-37$.

Os poços N10W39, N18W39, N20W39, N22W39, N8W40, N10W40, N20W40, N21W40, N22W40, N18W41 e N22W41 da ÄreaI, apresentam teores de $\mathrm{Ni}$ mais elevados em profundidade que devem corresponder a dunitos enriquecidos.

A sequência litológica vertical dos furos de sonda e dos poços e a configuração das rochas no mapa geolōgico in dicam que o flanco $W$ do maciço mergulha neste mesmo sentido.

0 flanco E, por sua vez, apresenta traços mais com plexos, observados nos seguintes furos:

F-6 (Area III), localizado em peridotito, passa a piroxenito, aproximadamente aos $48,0 \mathrm{~m}$ e volta a peridotito na profundidade de $53,0 \mathrm{~m}$; 


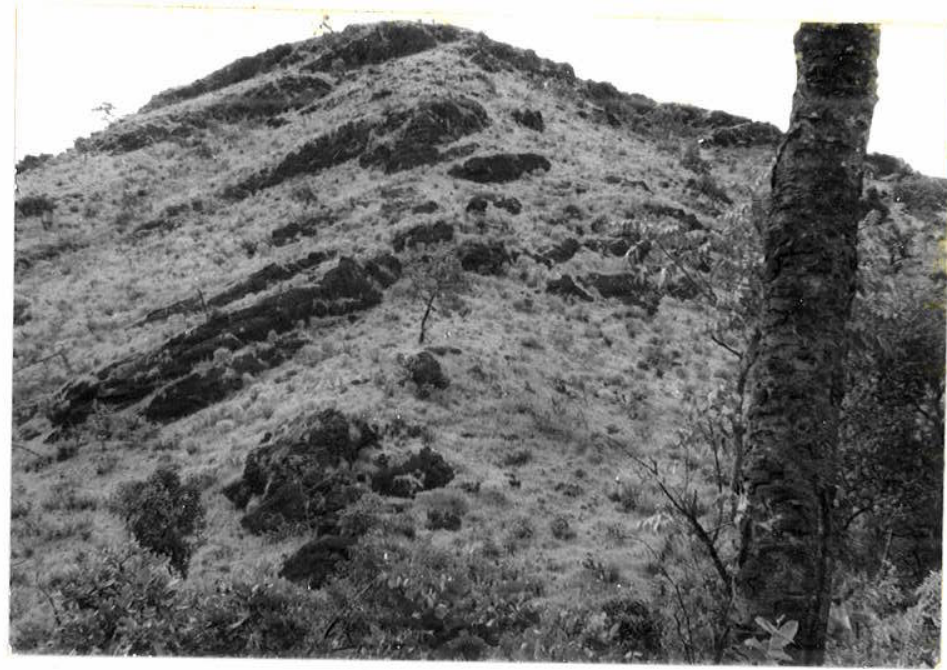

Foto 19 - Escalonamento da topografia formado por um sistema de fraturas. Morro do Tirapressa.

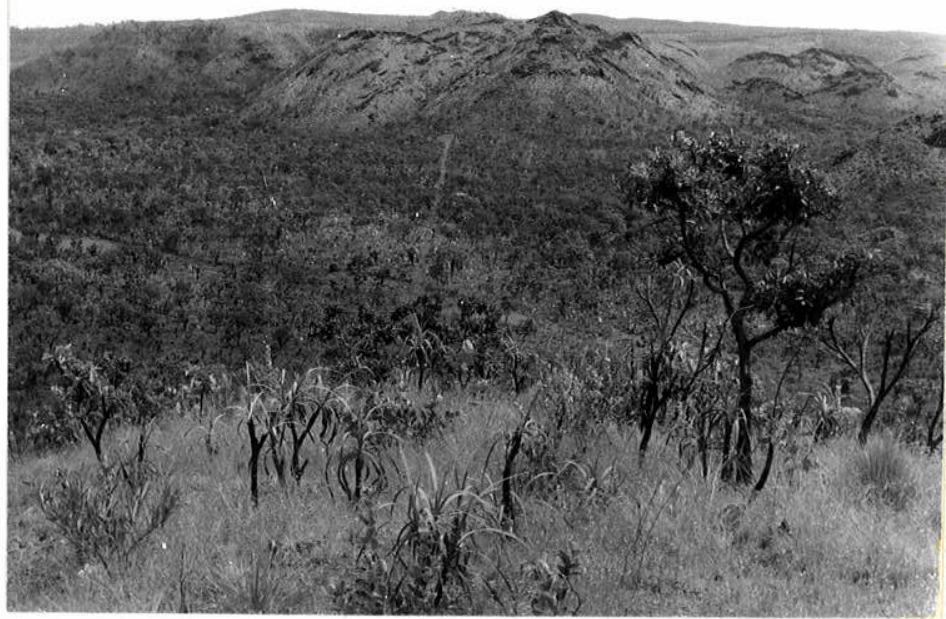

Foto 20 - Sistema de fraturas circulares provocando um aparente "descascamento" do Morro do Tirapressa.A dimensão não permite representação no mapa. Ao fundo maciço gnáissico capeado pelo Arenito Furnas. 
F-1 (Area II), localizado em hornblenda gnaisse,al cança peridotito aproximadamente aos $61,0 \mathrm{~m})$;

F-9 (Ārea IV), começa com dunito e passa, cerca dos $34,5 \mathrm{~m}$, a peridotito;

F-12 (Ārea VI), cuja seqüencia inicia-se com duni to e passa a peridotito na profundidade aproximada de 25,0m;

F-13 (Area IV), localizado em dunito, atinge o pe ridotito aos $27,0 \mathrm{~m}$;

F-17 (Ârea IV), que se inicia num dunito e atinge o peridotito aos $21,0 \mathrm{~m}$;

F-18 (Area IV), que atravessa inicialmente dunito e, em seguida, intercalações de dunitos e peridotitos;

F-11 (Area IV), que passa de dunito a peridotito aproximadamente aos $22,6 \mathrm{~m}$.

0 s demais furos de sonda atravessaram dunitos até o limite inferior de perfuração.

A sequência litolögica da borda $E$ do maciço indica uma deformação original do domo ou, então, um adernamento,com os contatos dunito/peridotito infletindo tambēm para W. Per turbações tectōnicas posteriores, talvez relacionadas às in trusões mais recentes, poderiam tambēm afetar a atitude or $\bar{i}$ ginal destes contatos.

$\mathrm{Na}$ ārea do Tirapressa, estruturas paralelas, com certo āngulo de mergulho, foram confundidas com pseudo-estra tificação, mas, na realidade, correspondem à expressão super ficial de um sistema de fraturas que escalona a topografia (Foto no 19) e segue grosseiramente os contatos do maciço com as encaixantes, aparentemente "descascando" a intrusiva (Foto nọ 20). Nesta mesma àrea podem ser vistos dois siste mas de fraturas em atitude grosseiramente perpendicular, como o caso da Foto 21. 


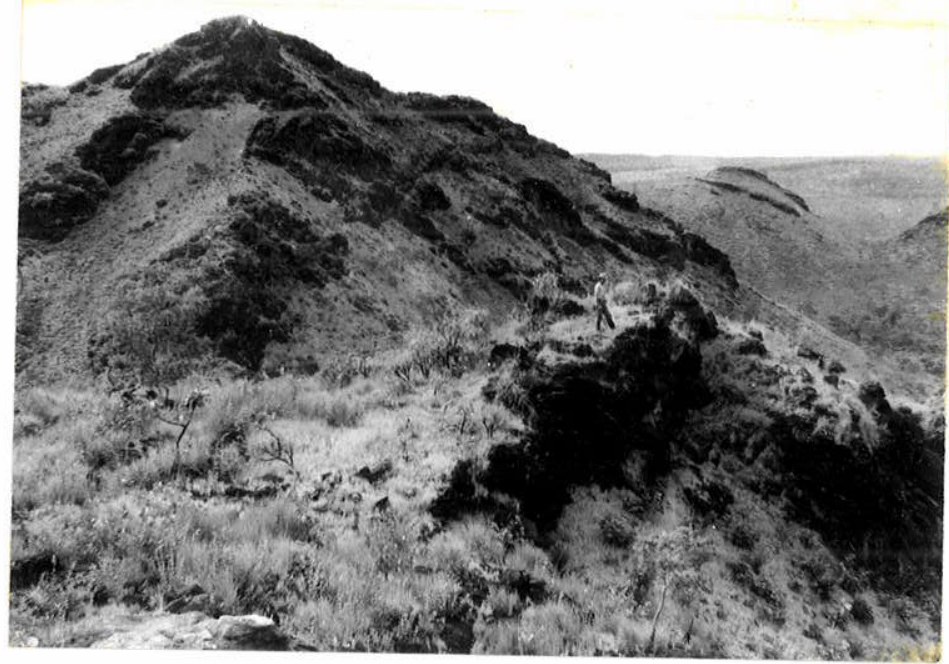

Foto 21 - Sistema de fraturas circulares, paralelo ao plano da foto, visível também no morro ao fundo. Outro sistema perpendicular ao primeiro, ē visivel no morro em primeiro plano. As faixas escuras são des níveis topograficos provocados pelos planos de fra tura.

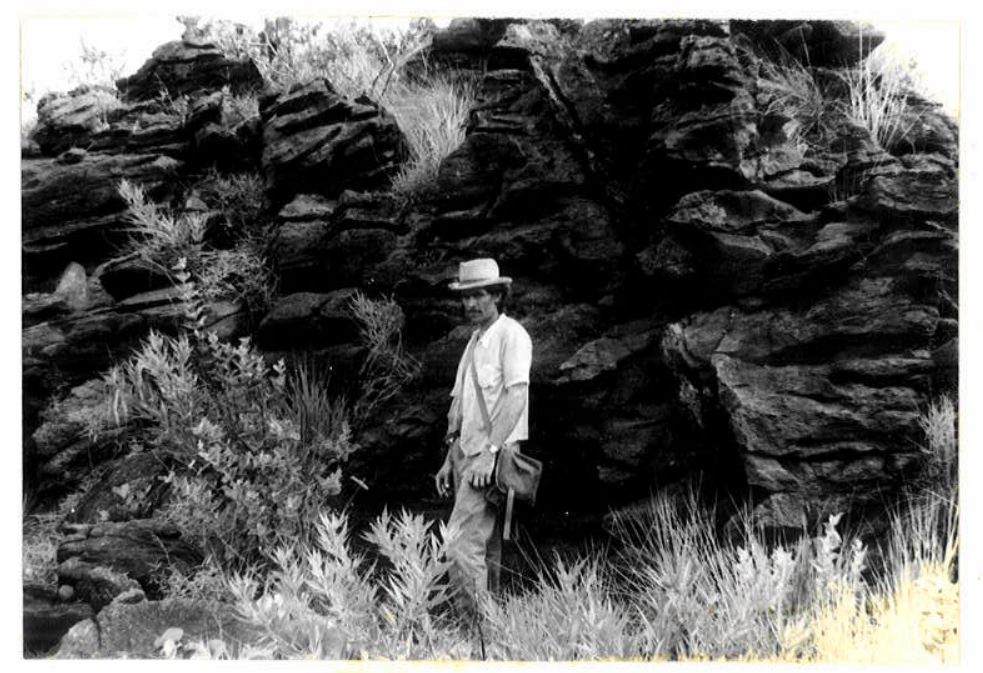

Foto 22 - Sistema horizontal de fraturas em zona de dunitos serpentinizados. Morro do Tirapressa. 
Um exame mais pormenorizado do mapa da Figura 3 ressalta os seguintes traços estruturais:

Porção SE do Tirapressa (Äreas IV, VI e VII)

Sistema principal do distrito, com fraturas e fa Thas de direção entre N $40-65^{\circ} \mathrm{E}$.

Porção S do Tirapressa (Ärea VII)

Pequenas fraturas de direção predominante $E-W$.

Porção SW do Tirapressa (Äreas VI e VII)

Vales encurvados segundo os contatos com as encai xantes.

Porção a $N$ da ārea central do maciço (Morros do Nióbio, Abandonado e da Vermiculita)

Sistema de fraturas locais, não mapeāveis, de dire ção predominante $N 20^{\circ} \mathrm{E}$.

Generalizando os traços estruturais de todo o dis trito, três sistemas podem ser evidenciados:

1) Sistema de fraturas paralelo ao contato da in trusiva com as encaixantes, sendo de pequena extensão hor zontal e responsāvel pelo escalonamento das encostas dos mor ros periféricos. Devem ter se originado dos esforços de in trusão, motivo pelo qual são circulares;

2) Sistema constituīdo por grandes fraturas e fá lhas de direção não coincidente com os contatos. Orienta al gumas escarpas, vales e espigões. Originou-se de esforços dirigidos, talvez relacionados à intrusão ou intrusões pos teriores; e

3) Um terceiro sistema de microfraturamento, or $\underline{i}$ ginado durante a serpentinização das ultramāficas e que faci litou sobremodo a alteração secundāria das rochas, o enrique 
cimento em $\mathrm{Ni}$ e a formação de "box-work" silicoso.

Um denso sistema de fraturas, de atitude horizon tal a sub-horizontal, partiu toda a rocha em alguns locais do Tirapressa. Deve ter se originado, direta ou indiretamen te, do processo de serpentinização das ultramāficas. Esté sistema é mais visĩvel no topo de alguns morros na ārea do Tirapressa (Foto 22).

A hidrografia na ārea do distrito é grosseiramente radial sem mostrar qualquer controle estrutural. Todavia, há uma visível influência do mergulho regional com caimento pa ra NW, em direção à bacia do Rio Araguaia.

\section{CAPITULO VIII}

\section{ALTERAÇÃO DAS ULTRAMĀFICAS}

os principais agentes de alteração, assim como os produtos formados e seu posicionamento no perfil vertical, são tratados mais especificamente neste capítulo. A distri buição vertical predominante da calcedônea, magnesita e ga nierita é discutida dentro dos aspectos mais significativos do modo de ocorréncia e relacionamento com o solo ferraliti co marrom, solo ferralītico amarelo e rocha ultramāfica em seus graus de alteração. Como controle atuante na alteração, foi considerada a posição do nível hidrostático, sua varia ção sazonal e variação com o afastamento dos cōrregos que cortam o distrito. 
Antes de considerarmos os efeitos da alteração se cundāria sobre as rochas do distrito, é oportuno lembrar que este processo deve ter sido precedido por uma serpentini zação generalizada das rochas olivínicas e que teve origem mais profunda, atuando por agentes hipögenos ascendentes.

Nas colunas esquemāticas descritas a seguir foi tentada uma generalização do comportamento de alguns mine rais nos perfis verticais, evitando-se as mudanças e varia ções locais dependentes da litologia e topografia.

Centenas de poços descritos, testemunhos de sonda gens e trincheiras permitiram traçar duas colunas esquemáti cas genēricas, a primeira para topos e encostas de elevações e a segunda para areas planas e baixas. Nestas, tentou-se de limitar a distribuição quantitativa aproximada da vermiculí ta, magnesita, garnierita, laterita oolítica solta, calcedō nea, crostas de laterita e tipos de minērios. 0 perfil de solo (Figuras 9 e 10) foi dividido em zonas de altera ção, de acordo com os minerais encontrados e o grau de alte ração. Resultados de anālises quỉmicas complementaram as observações.

$\mathrm{Na}$ Figura 9, representativa de āreas planas e baixas, observa-se que:

além da crosta de laterita formada em alguns pon tos superficiais, existe outra de origem química, de pequena espessura, formada na interfācies entre o solo ferralitico marrom e o solo ferralítico amarelo. Esta interfácies cor responde a uma zona de maior permeabilidade, aliada a uma zo na de variação do grau de oxidação do elemento Fe que muda de coloração. Esta crosta não é encontrada em todos os po 
Fig. 9- COLUNA ESQUEMÁTICA GENÉRICA - ULTRAMÁFICA DE STA.FÉ GOIAS-AREA PLANA E BAIXA

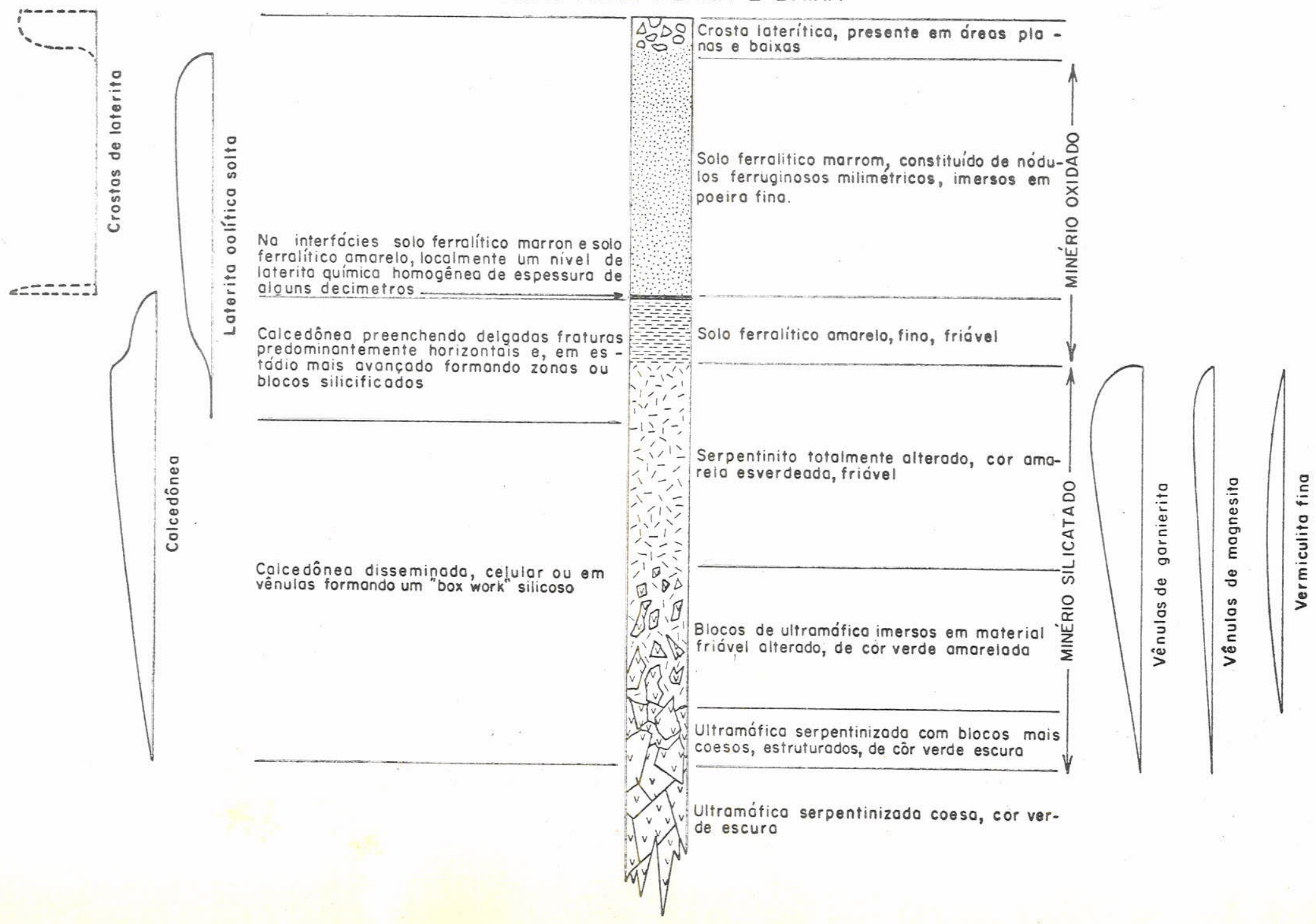


Fig. 10- COLUNA ESQUEMÁTICA GENÉRICA - ULTRAMÁFICA DE STA. FÉ ÁREA DE TÔPO E ENCOSTAS INGREMES DAS ELEVAÇOES

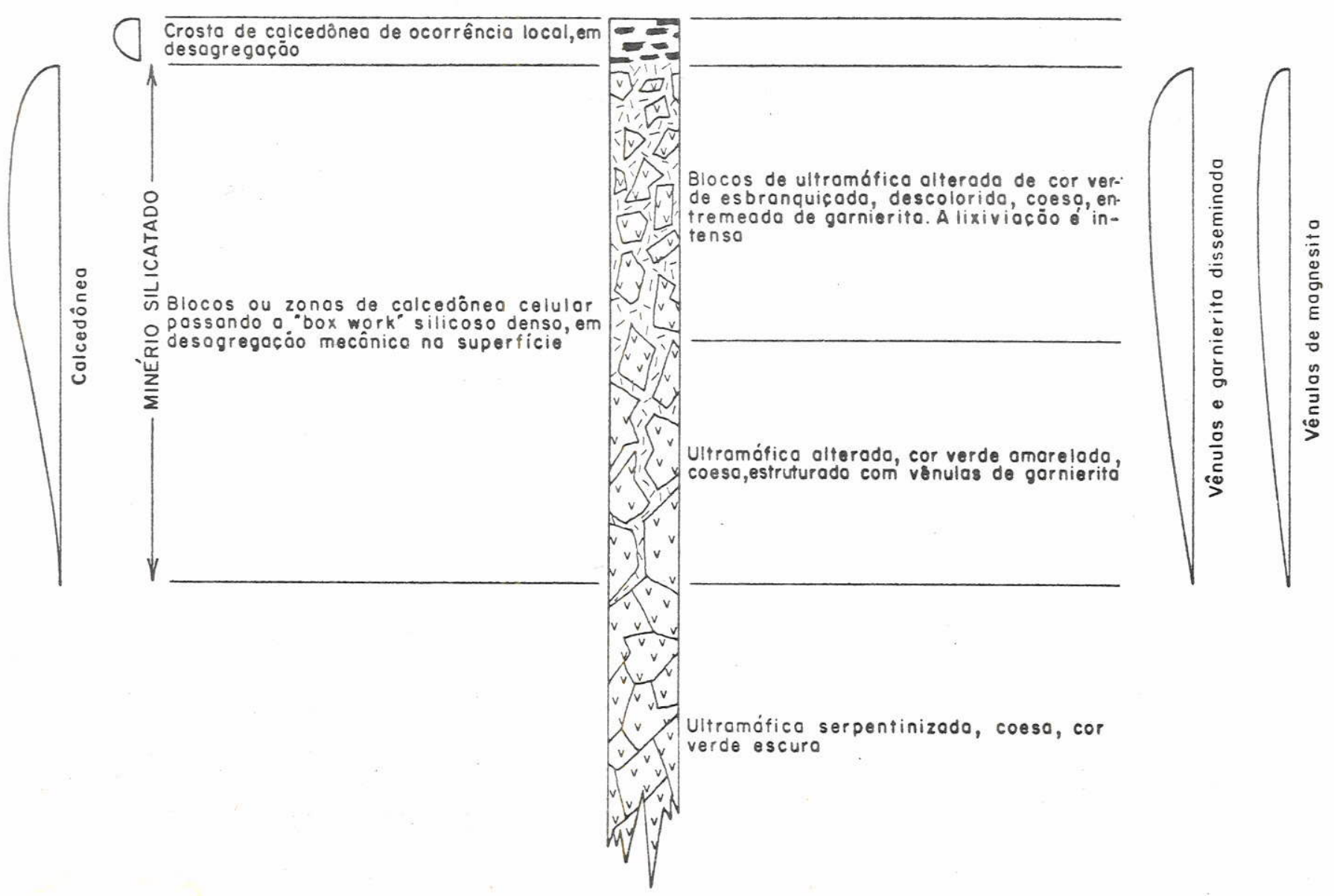


ços, mas, nota-se, quando de sua ausēncia, uma incipiente la terização. Aparentemente, ela não tem relação direta com a variação do nível hidrostātico que se localiza atualmente bem abaixo, mas, com o mais livre fluxo lateral da àgua de infil tração ao longo da interfācies. Mudanças físico-químicas de terminam a deposição do Fe neste nĩvel;

- solo ferralítico marrom e amarelo constitui miné rio do tipo oxidado, passando, abaixo, a minërio silicatado, pela presença de silicatos portadores de Ni, a exemplo da garnierita;

a calcedōnea jā estā presente, se bem que quantita tivamente subordinada, no solo ferralítico amarelo. Abaixo deste ela constitui vênulas predominantemente horizontais ou blocos silicificados, passando em profundidade para material disseminado ou "box work" silicoso;

A garnierita, assim como outros minerais portadores de $\mathrm{Ni}$, são representativos quantitativamente no saprōlito fino, logo abaixo do solo ferralitico amarelo, diminuindo em direção ao serpentinito menos alterado;

as vênulas de magnesita, que são visĩveis no topo do serpentinito alterado, diminuem com a profundidade; e

a vermiculita fina não tem um comportamento previ sível, motivo pelo qual pode ser originada tambēm no proces sso prēvio de serpentinização.

Quanto à Figura nọ 10, referente às āreas de topo e encostas das elevações, observa-se que:

a calcedōnea estā presente, ao longo de todo o per fil, na forma de crosta de ocorrência esporādica, na super fīcie topogrāfica, ou em zonas do "box work" silicoso, no saprōlito fino superficial ou grosseiro, mas diminuindo em direção à base do perfili; 
a garnierita e a magnesita estendem-se desde o to po atē a base do perfil, mas, ambas diminuem com a profundi dade.

Nesta coluna não estā presente minērio do tipo oxi dado. Minério silicatado estende-se desde o topo até a base do perfil.

A intensidade do processo de alteração das rochas ao longo do perfil vertical depende da posição do nīvel hi drostático, assim como sua variação sazonal. Em mais de uma centena de poços, terminados ao atingir o nīvel hidrostātico, foram feitas medidas de profundidade, do nīvel de āgua, e, em muitos casos, mais de uma medida, de modo a registrar a va riação do nīvel em duas ēpocas diferentes do ano. A Tabela nọ 1 mostra a profundidade do nível hidrostātico a distān cias horizontais crescentes dos cörregos locais, evidenciando - aprofundamento do nível com a distância horizontal cres cente aos cōrregos mais próximos.

A elevação māxima e mīnima do nīvel hidrostātico, da qual foi calculada a média da Tabela nọ 1, não representa os valores máximos e minimos reais. As medidas foram feitas em värias épocas do ano, desconhecendo-se quando estes valo res são extremos.

Para simples efeito de comparação, foi colocada na ūltima linha da mesma tabela, a mēdia de três medidas feitas em encostas de morros.

Em āreas planas, distantes mais de $300 \mathrm{~m}$ de cōrre gos, foram feitas cento e vinte e uma medidas da profundida de do nīvel hidrostātico, colocando-se em histograma as por centagens dos valores obtidos (Figura nọ 11).

Cinco a dez metros representam a profundidade mais comum do nīvel hidrostātico em zonas planas e rasas. Esta profundidade coloca, estatisticamente, o nỉvel hidrostātico 
TABELA 1

PROFUNDIDADE DO NIVEL HIDROSTATTICO EM FUNÇĀO DA DISTANNCIA AOS CORREGOS - TOPOGRAFIA PLANA

Dístância aos

cörregos (m)

$0-25$

$25-50$

$50-75$

$75-100$

$100-125$

$125-150$

$150-175$

$175-200$

$200-225$
Profundidades mēdias

nīvel hidrostātico (m)

2,7

3,5

4,1

3,8

4,3

4,5

4,5

5,1

5,2
Nūmero de medidas

9

7

9

8

9

5

5

10

13

Encosta de morro

5,1 3

no saprōlito fino, no topo da ultramāfica alterada, indo atē zonas mais profundas de saprölito mëdio a grosseiro.

As Figuras nrs. 12 e 13 representam perfis com a posição do nīvel hidrostático, assim como sua variação, ao longo das linhas E 6 e E 10. Alguns poços ou furos de sonda contêm a descrição das zonas de alteração. Confirma-se a observação feita antes de que a zona de variação do nĩvel hi drostātico localiza-se abaixo do solo ferralítico amarelo.

Nota-se, tambēm, nestes dois perfis, que o nīvel hidrostātico segue grosseiramente a topografia, com uma pe quena defasagem. 0 fato do nīvel não emergir na superfície no cörrego Ponta de Pedra em ambos os perfis indica que as medidas foram tomadas em periodo de menor pluviosidade, caracterizando a intermitência deste segmento do cōrrego.

A verificação do comportamento do $\mathrm{Ni}$, em relação à posição do nīvel hidrostātico dentro de suas variações lo- 


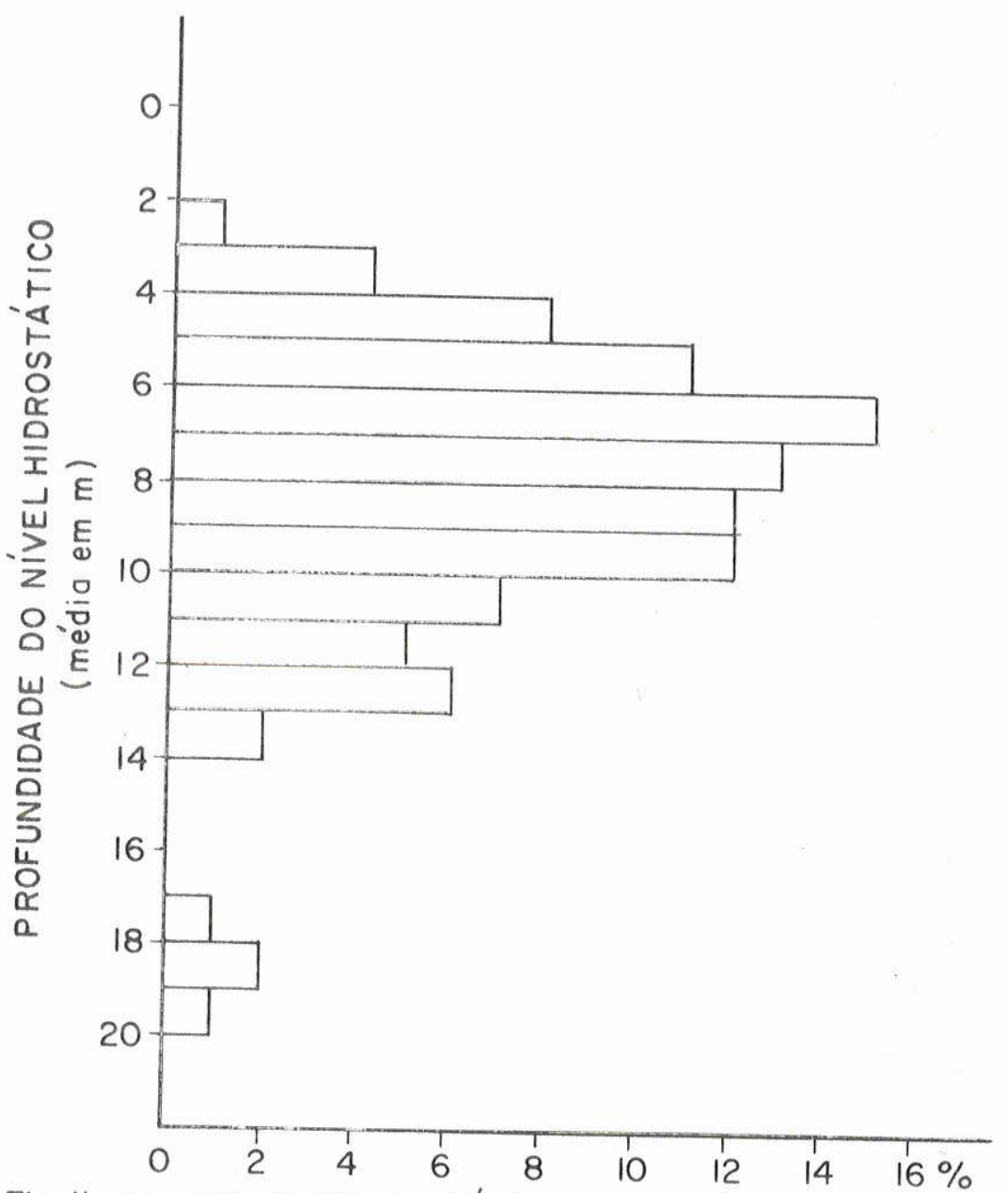

Fig. II-PROFUNDIDADE DO NIVEL HIDROSTÁTICO MEDIDA EM ZONAS PLANAS E RASAS, A DISTÂNCIAS SUPERIORES A $300 m$ DOS CÓRREGOS. (n de medidas: 121) 
Fig. 12-PERFIL DOS POCOS E SONDAGEM AO LONGO DA LINHA E 6

\section{Córrego}

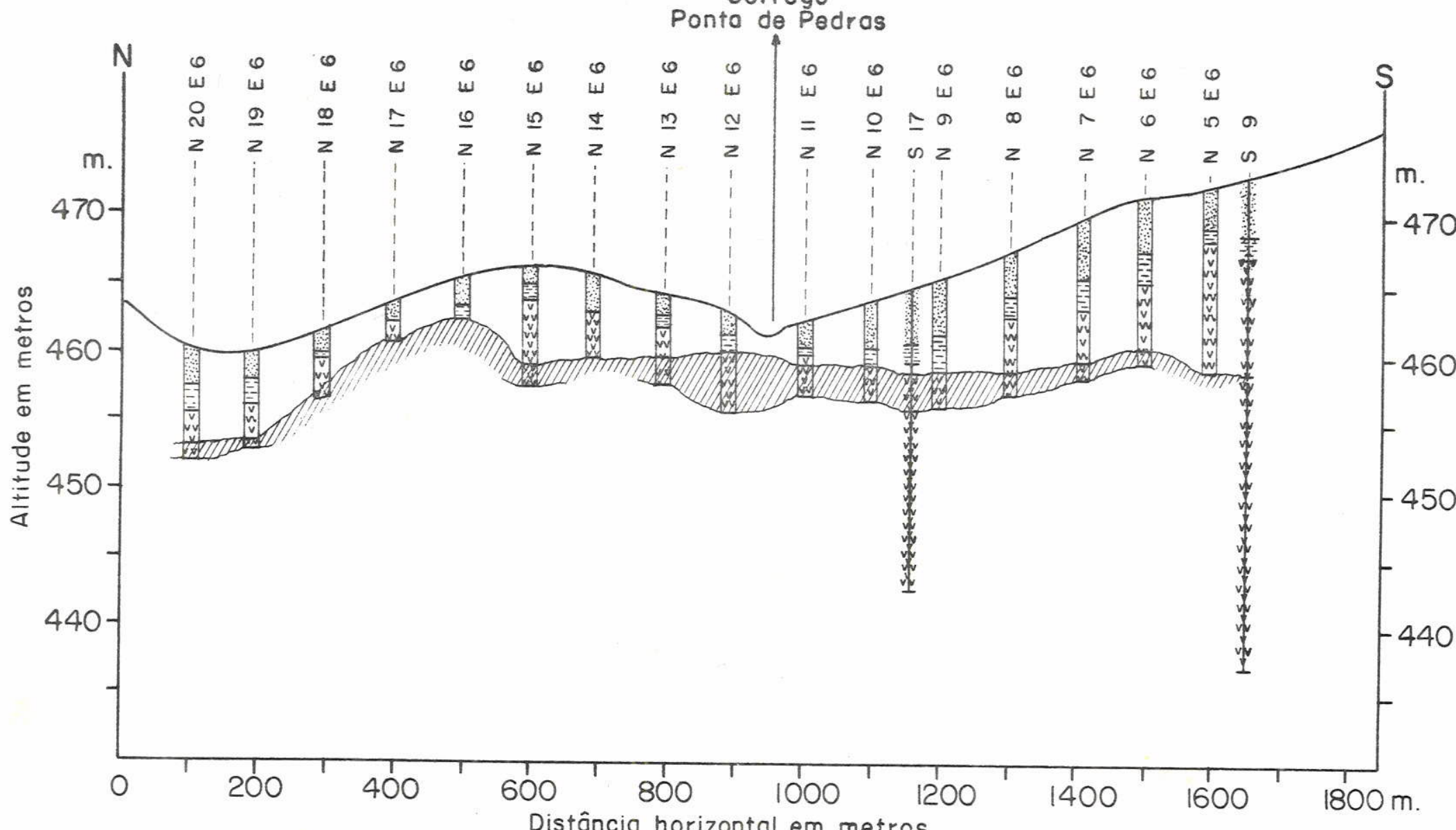

LEGENDA

\begin{tabular}{|c|c|}
\hline 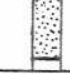 & Solo ferralítico marrom \\
\hline 囯薗 & Solo ferralítico amarelo \\
\hline 原 & Dunito alterado \\
\hline
\end{tabular}

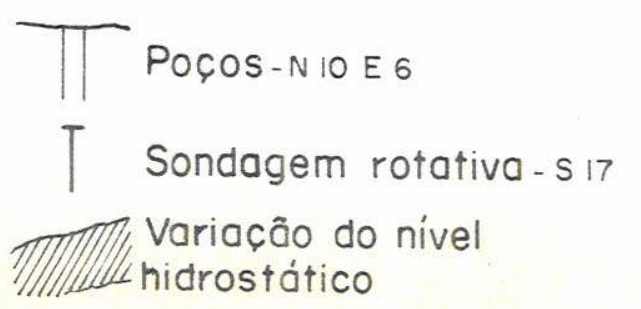


Fig. 13-PERFIL DOS POÇOS AO LONGO DA LINHA E 10

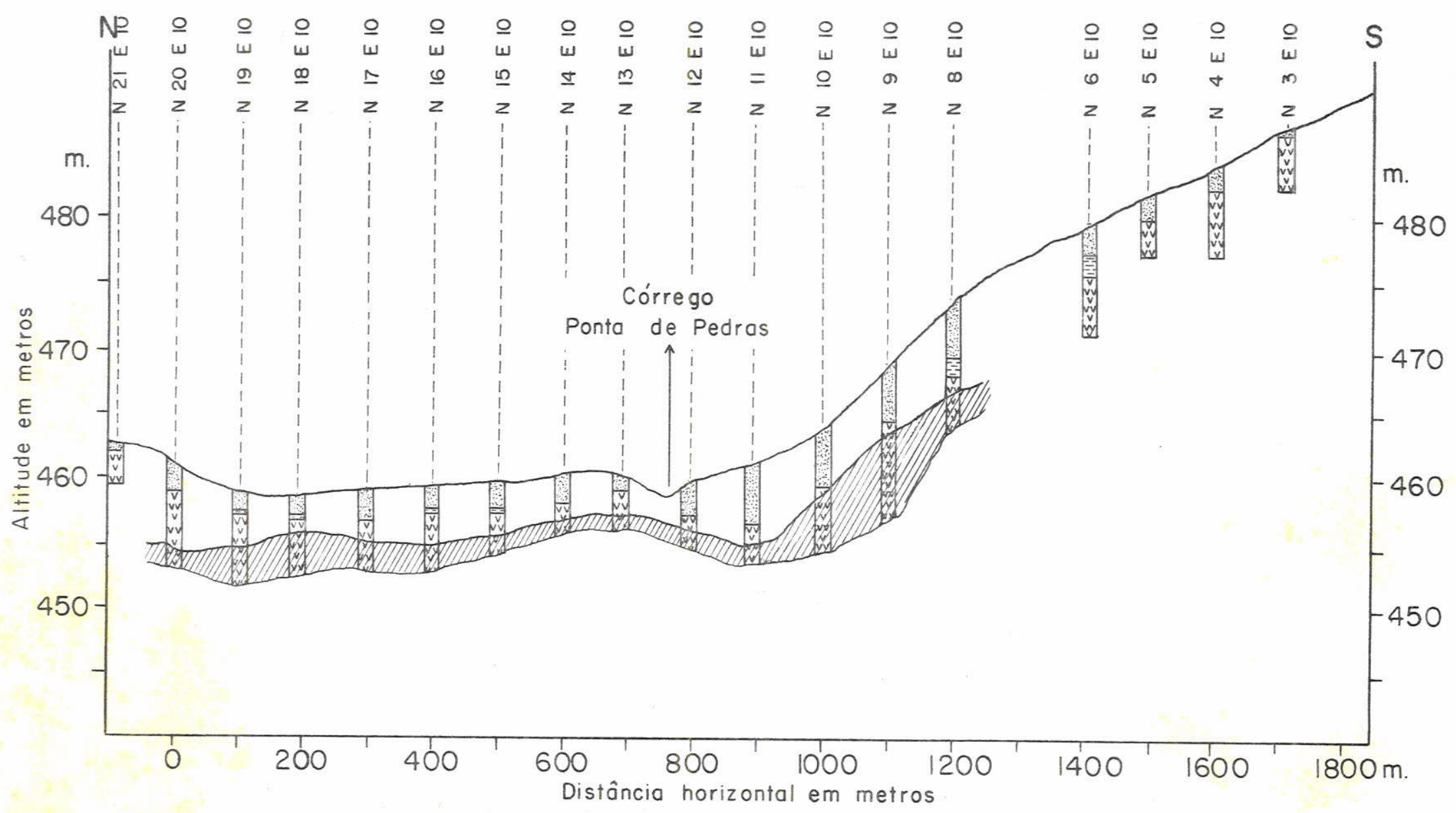

LEGENDA
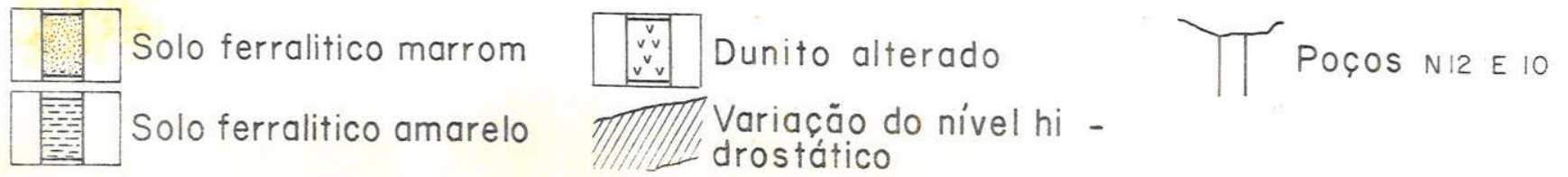
cais, foi feita combinando-se em um perfil vārios poços, com os respectivos teores de $\mathrm{Ni}$ e a profundidade do nivel hidros tātico, e, quando possīvel, sua variação. Todas essas variā veis foram comparadas em poços com distâncias crescentes aos cōrregos prōximos. A Figura no 14 indica que os maiores teores de $\mathrm{Ni}$ estão no saprōlito fino, no topo da ultramāfica alterada, e que os "picos" de teores vão desaparecendo con forme o poço localiza-se mais prōximo do cōrrego, a $W$ do perfil. Nas zonas mais distantes dos cörregos o enriqueci mento de $\mathrm{Ni}$ se dá acima da zona de variação do nível hidros tātico. Conforme se aproxima do cörrego, este comportamentó jā não fica muito nîtido, com aumento da porcentagem de $\mathrm{Ni}$ mesmo abaixo do nível hidrostātico registrado. 0s "picos" desaparecem e dão lugar a uma distribuição mais homogēnea do Ni no sentido vertical. E igualmente óbvio o aprofundamento do nível hidrostático nos poços mais afastados dos cōrregos locais.

0 processo de alteração leva à formação de agrega dos de minerais e rochas mais ou menos porosos e de densida des variāveis com a profundidade. Amostras coletadas em ārea de dunito foram submetidas à determinação da densidade aparente, obtendo-se variações ao longo do perfil vertical.

0 solo ferralítico marrom e amarelo foi coletado e trazido para o laboratōrio, colocando-se este material incoe rente em uma proveta graduada. De posse do volume aparente, as demais variāveis foram determinadas, obtendo-se os valo res do grāfico da Figura nọ 15. Amostras coesas, coletadas desde o saprōlito fino, abaixo do solo ferralítico amarelo, até a base do perfil, foram envolvidas em parafina, obtendo-se o peso específico aparente em balança Westphal Mohr.

Comparando-se as Figuras 15 e 19, observa-se que, em āreas de dunitos e peridotitos, a densidade pode ser con 
Fig. 14-PROFUNDIDADE DO NIVEL HIDROSTATICO E TEORES DE NI A DISTÃNCIAS VARIÁVEIS DOS CÓRREGOS
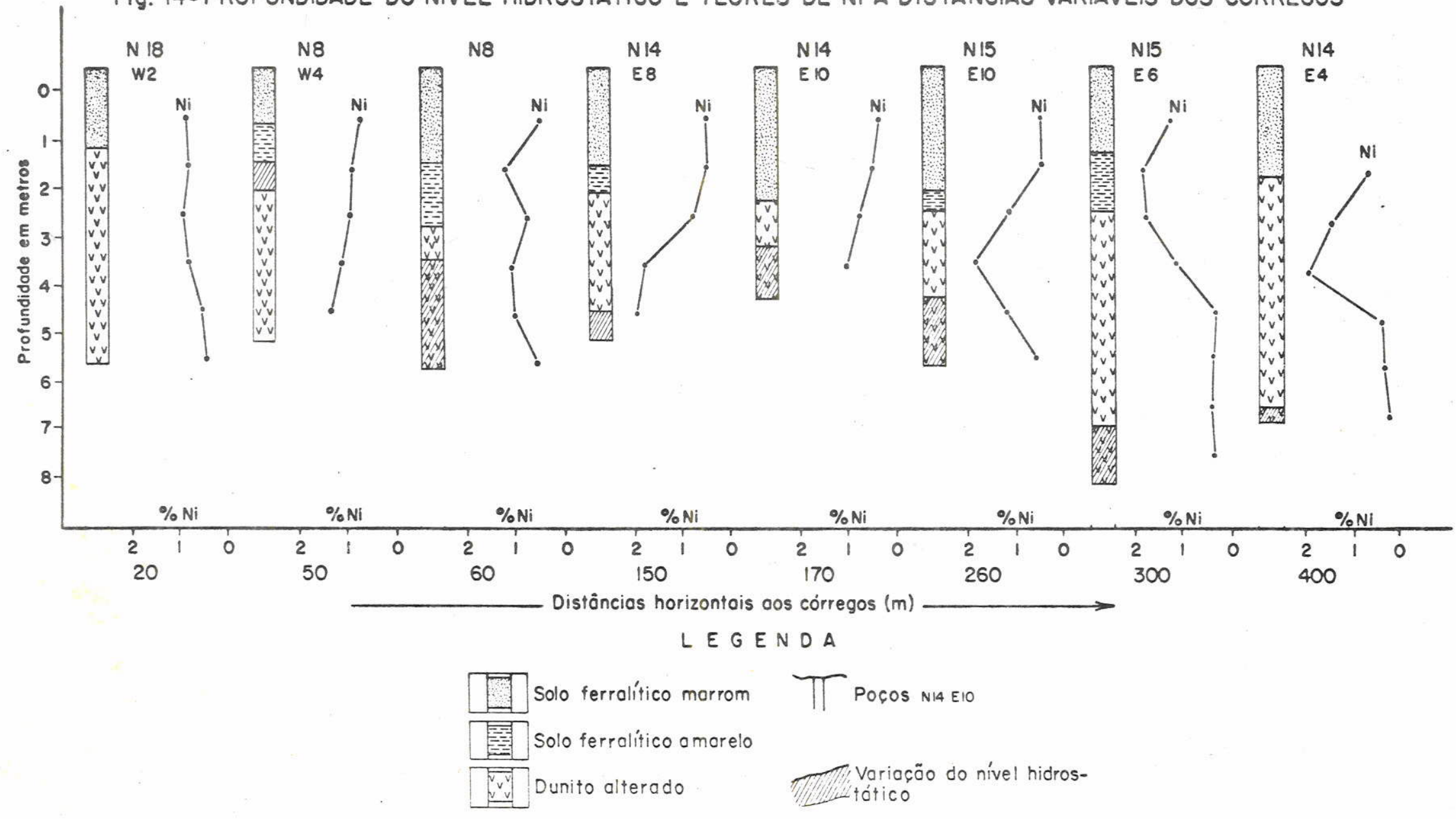

$$
\text { E G ENDA }
$$

TPOCOS N14 EIO

Tilisação do nível hidros- 
Fig.l5-VARIAÇẢO DA DENSIDADE COM A PROFUNDIDADE EM ÁREAS DE DUNITOS

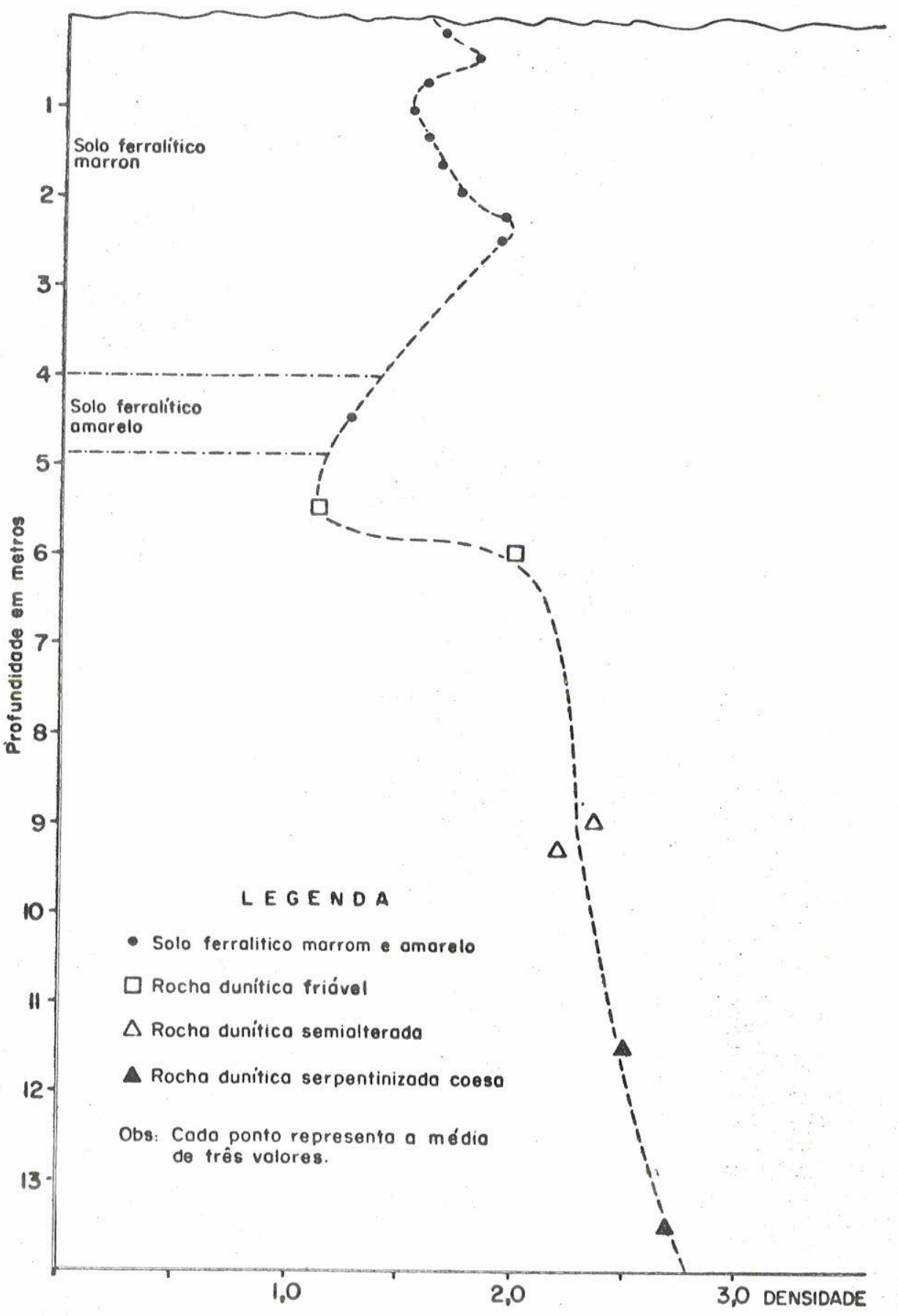


siderada inversamente proporcional aos teores de $\mathrm{Ni}$ e que esta assertiva é vālida para as zonas de ultramāfica"in situ", excetuando-se as zonas de solo ferralïtico marrom e amarelo que não mantêm esta proporcionalidade.

As interpretações feitas neste capítulo devem, na turalmente, ser analisadas sob o ponto de vista de um proces so de alteração dinâmico no tempo e no espaço, dependente tám bēm de condições climāticas e topogrāficas pretēritas. A so breposição no perfil de alteração de vārias mudanças físicas e quĩmicas não permite observações mais precisas sobre o pro cesso de alteração das rochas do distrito, alēm de tornar di fícil o estabelecimento da cronologia e duração destas mudan ças.

VIII.I - CONCREÇÕES OOLITTICAS - SOLO FERRALITICO MARROM

A alteração das ultramāficas e a erosão das partes topograficamente mais salientes concorreram para o acūmulo, nas zonas mais baixas, de um solo ferralitico de cor marrom que capeia a rocha alterada "in situ". Este solo tem espes sura mēdia de $4 \mathrm{~m}$ e é composto de concreções sub-milimētricas, soltas, imersas em uma massa (matriz) fina, ferruginosa, con tendo concreções pisolîticas dispersas (Foto 23).

As concreções são arredondadas,predominantemente de forma esfērica, e de alta suscetibilidade magnētica (Foto 24).

Antes de estudarmos a sua composição, vejamos sua distribuição granulomētrica. Pela topografia pode-se avaliar a variação da espessura do solo ferralítico marrom. Ele é delgado nas encostas suaves dos morros e espesso nas zonas 


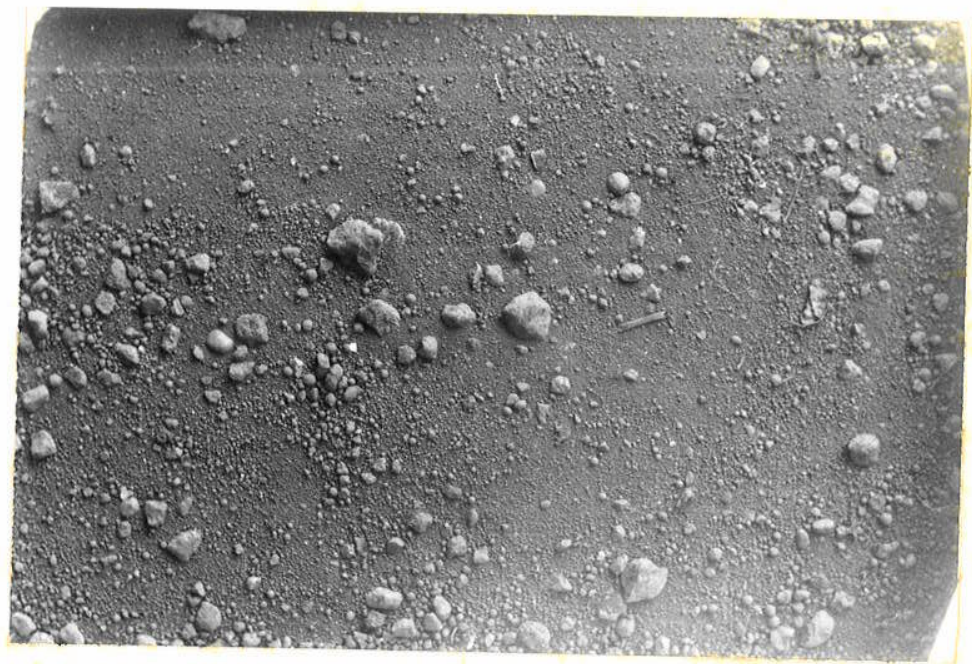

Foto 23 - Concreções ooliticas soltas, imersas em massa ferruginosa fina. Alguns pisōlitos dispersos (tamanho natural).

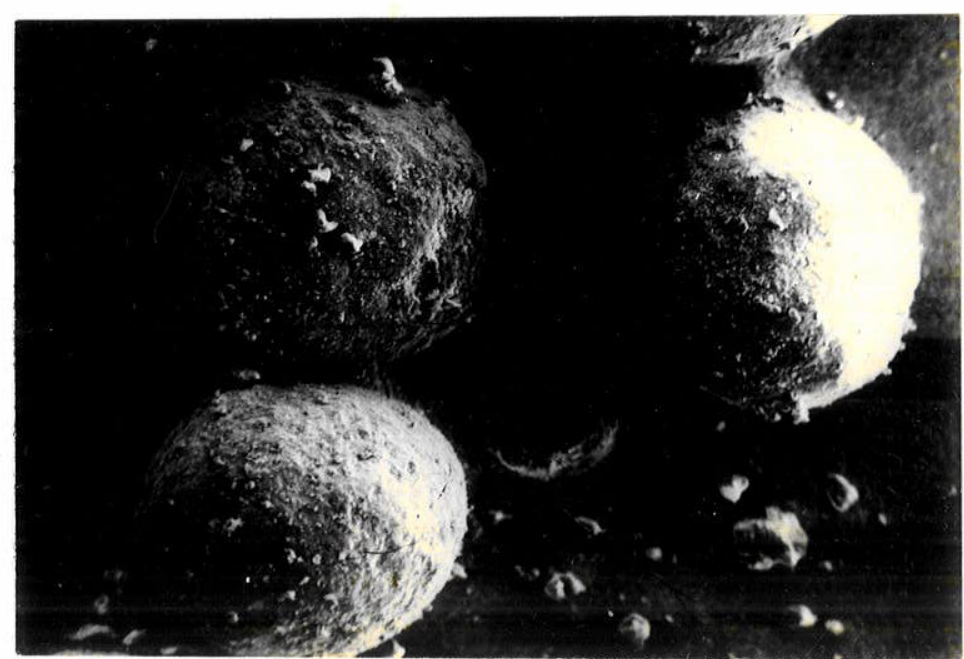

Foto 24 - Concreções oolĩticas soltas. Microscōpio eletrônico de varredura. Aumento $100 \mathrm{X}$. 
entre-morros, atingindo valores māximos nas zonas baixas ar rasadas pela erosão.

De modo a confirmar a homogeneidade da granulação das concreções na horizontal e verificar a fração predominan te, três amostras coletadas em pontos diferentes mostraram os seguintes resultados:

A frequência em porcentagem predominante situa-se entre 32 e 115 mesh. Se bem que trēs amostras não devam re presentar toda a ārea, elas parecem indicar uma distribuição granulométrica horizontal homogênea, com predominância das frações citadas acima.

0 concrecionamento e as frações predominantes em um perfil vertical mostraram os mesmos valores do grāfico an terior, indicando, talvez, um processo de concrecionamento homogêneo com a profundidade ou, o que é possīvel e mais viā vel, um processo de erosão e abaixamento topogräfico muito rāpido que homogeneizaria a dimensão das concreções tanto nos nĩveis de formação mais novos quanto nos mais antigos.

0 nūcleo das concreções pode ser constituído de cristais de magnetita (25\%), sem nūcleo visível (61\%) e de fragmentos de concreções (14\%). A parte central de algumas concreções sem nūcleo visīvel tem maior refletividade, menor porosidade, indicando talvez um grau de desidratação maior, com a formação de minerais intermediārios menos hidratados, a exemplo da goethita.

Uma mesma concreção admite mais de um nūcleo,assim como pode ter octaedros de magnetita e cristais de quartzo dispersos sem qualquer preferēncia nas camadas internas ou externas da concreção.

A presença de nūcleos formados de fragmentos de concreções deve indicar que algumas delas fragmentaram-se 
Fig. 16-DISTRIBUIÇÃO GRANULOMÉTRICA DAS CONCREÇÕES NA ZONA TOPOGRA'FICA SUPERFICIAL

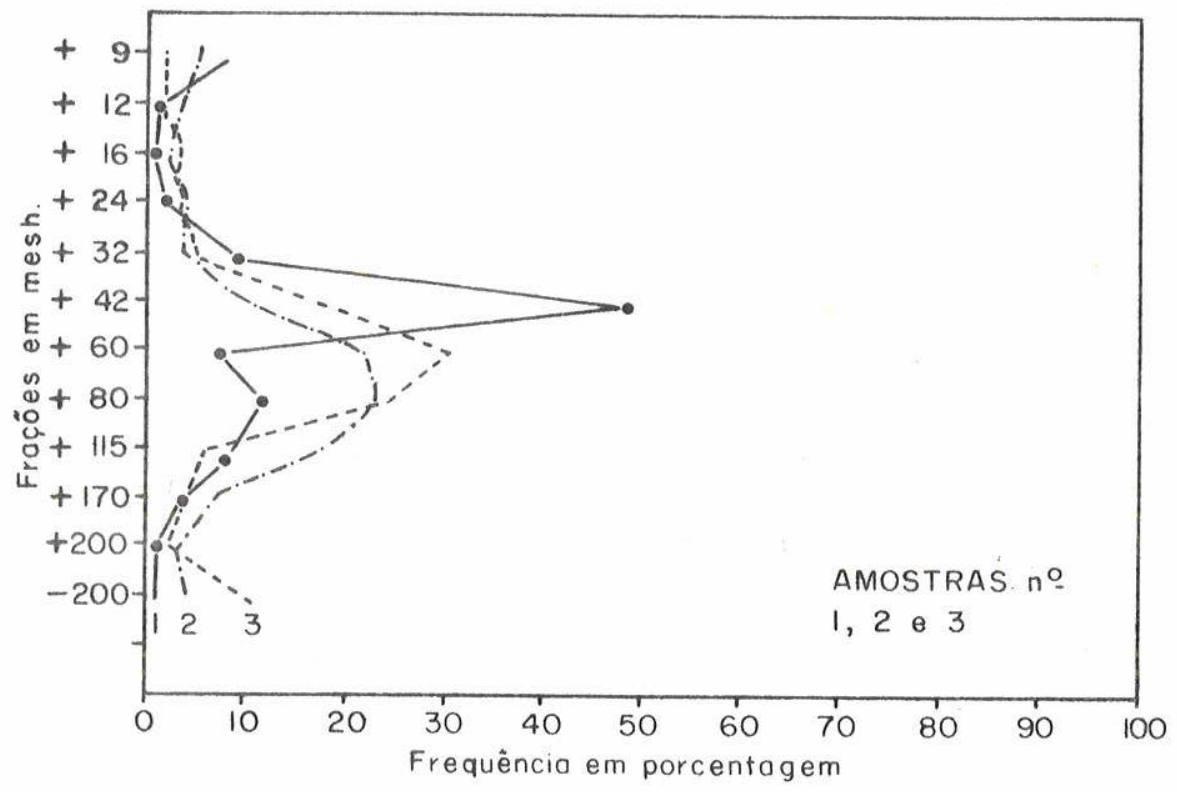


Fig. 17-DISTRIBUIÇĀO GRANULOMÉTRICA DAS CONCRECODES COLETADAS EM SEGMENTOS VERTICAIS DE TRINTA CENTIMETROS

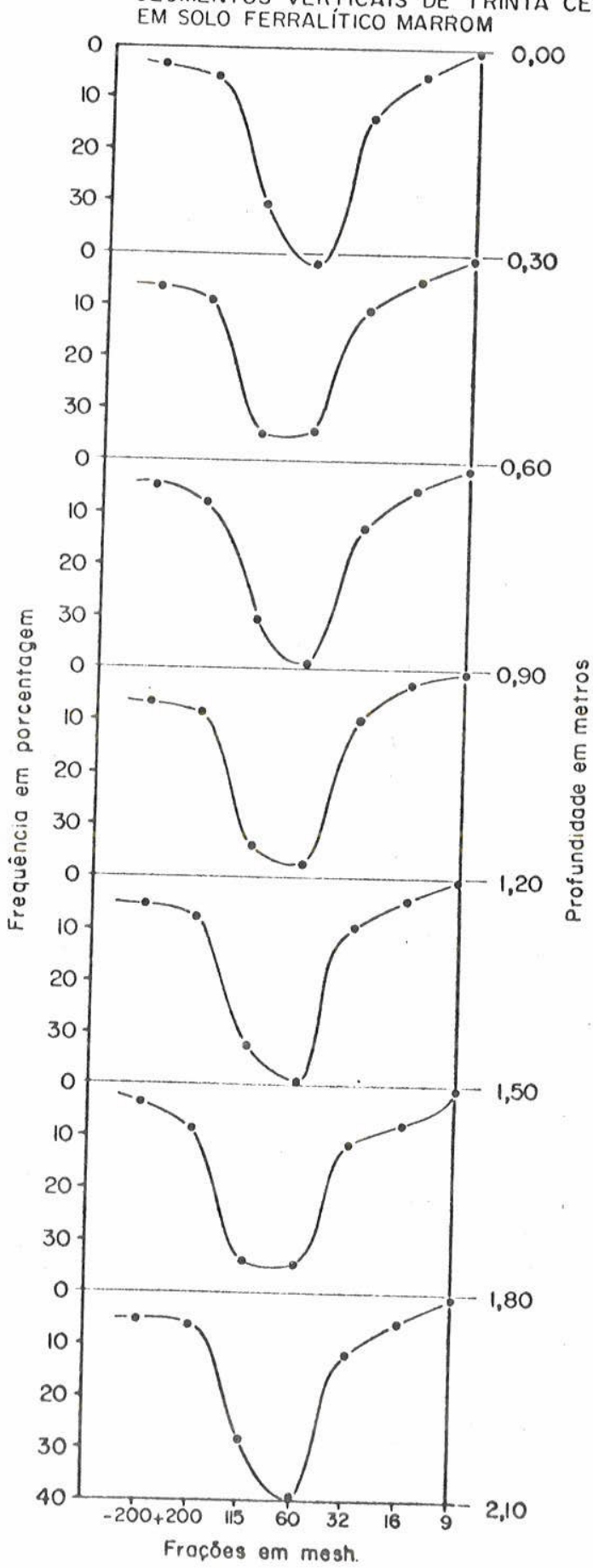


ainda na fase coloidal e vieram a constituir os nūcleos das novas concreções. Tanto quanto é possível observar, fragmen tos das zonas centrais do nūcleo são mais comuns, talvez in dicando sua parcial desidratação e endurecimento, possibili tando fragmentação e transporte.

Alguns cristais de magnetita agregados nas concre ções apresentam lamelas de ilmenita ao longo dos planos (111). Tanto quanto se pode notar, não houve tempo para a oxidação dos cristais de magnetita durante o processo de con crecionamento.

Esporadicamente são vistos grãos de cromita cimen tados nas concreções, assim como grãos constituĩdos de goe thita fibrosa, levemente anisōtropa, com refletividade maior do que aquela apresentada pelos minerais constituintes das camadas das concreções.

Concreções cimentadas apresentam um sistema de mi cro-fraturamento que toma atitude radial, concêntrica ou anastomosada e que se estende apenas até a borda da concre ção, sem atingir o cimento. Deve ter sido originado da desí dratação das camadas concēntricas, com redução de volume e consequente fraturamento.

A alteração e intemperismo das ultramāficas com opacos disseminados levam à formação de concentrados de cristais pela ação laminar das enxurradas. Estes cristais misturam-se às concreções na zona imediatamente superior do solo formando uma delgada cobertura. Uma cuidadosa separa ção dos cristais e das concreções em lupa binocular permi tiu a preparação de duas amostras que, submetidas a anālise química, mostraram os resultados das Tabelas 2 e 3.

Da comparação das duas tabelas pode-se observar as porcentagens maiores, no solo ferralítico marrom, de $\mathrm{SiO}_{2}$, 
TABELA 2 - CONCENTRADOS NATURAIS DE MINERAIS OPACOS

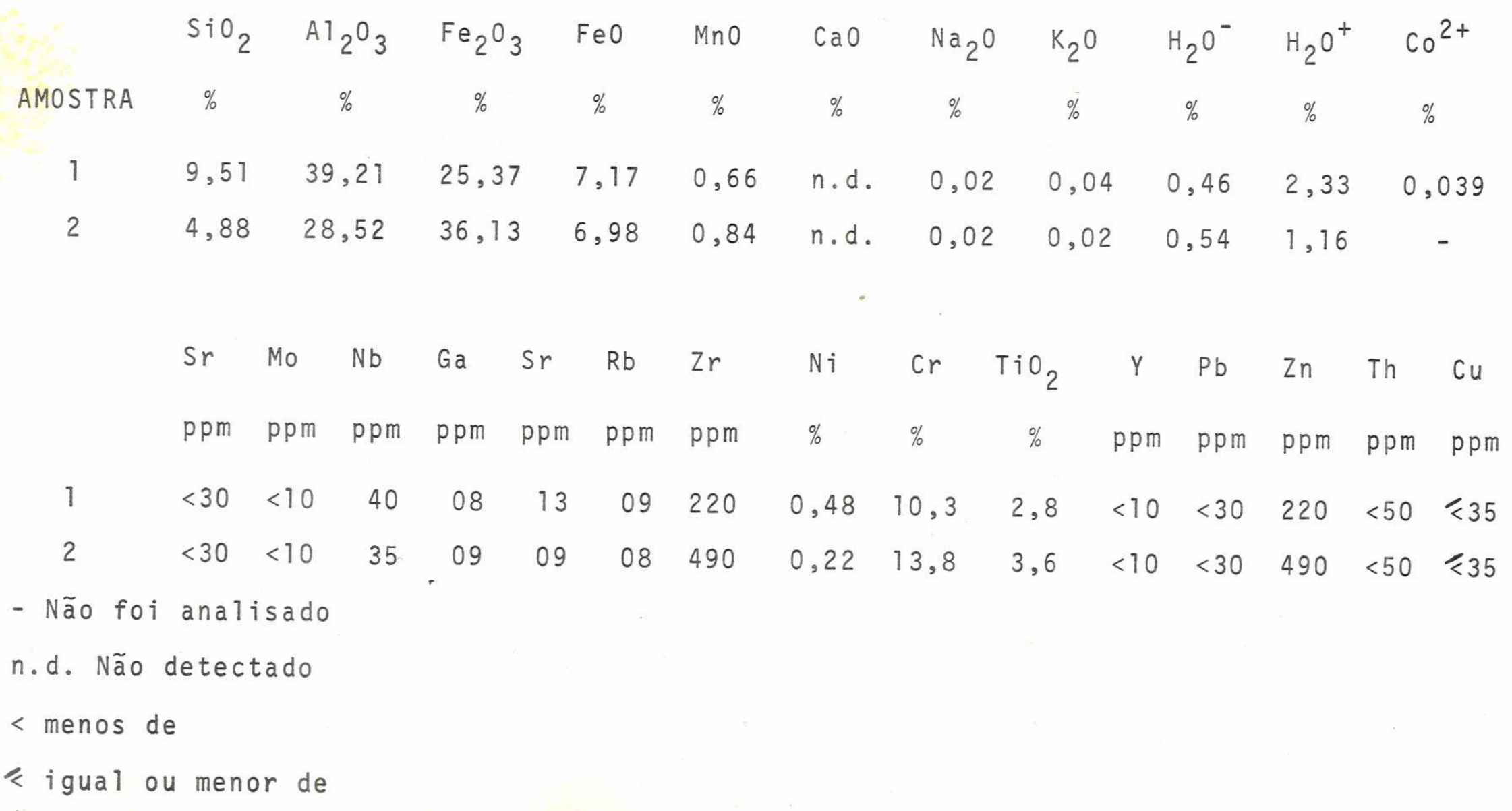


$\mathrm{Fe}_{2} \mathrm{O}_{3}, \mathrm{MnO}, \mathrm{H}_{2} \mathrm{O}^{+}$e $\mathrm{Nb}$. Assim, tambēm notamos uma porcenta gem maior nos concentrados naturais de minerais opacos dos seguintes componentes: $\mathrm{Al}_{2} \mathrm{O}_{3}, \mathrm{Fe} 0, \mathrm{Zr}$ e $\mathrm{Cr}$.

os dois grupos de amostras foram submetidos também à anālise de raios $X$, obtendo-se os difratogramas da Figura 18.

No difratograma 2 foi notada a presença de maghemi ta, dificil de ser identificada microscopicamente, principal mente devido ao fato de ocorrer na forma microcristalina. Es te mineral deve ter se formado pela alteração de magnetita, contida em ambas as amostras. Os resultados obtidos no di fratograma poderiam ser melhor utilizados se fosse feita uma separação prēvia dos componentes mineralógicos.

VIII.II - CONCREÇÕES PISOLITICAS - SOLO FERRALITICO MARROM

A capa imediatamente superior do solo ferralitico marrom pode ser localmente constituída de concreções pisolí ticas soltas. Estas apresentam a continuação do processo de crescimento concrecionārio em condições ambientais restri tas e predominantes em algumas äreas do distrito. Estas con dições, dimensionadas em seus limites físicos e químicos, for maram crostas contīnuas pela cimentação dos pisōititos supe $\underline{r}$ ficiais. Este capītulo trata deste tipo de concreção, enfó cando sua composição quỉmico-mineralōgica e as condições am bientais de formação. No estudo da composição foram utilizá dos os recursos da microscopia de luz refletida em associa ção com o estudo de imagens eletrōnicas de microssonda.

Em zonas mais ümidas, sujeitas a uma deposição quí mica mais intensa, as concreções desenvolveram-se mais rapi 


\section{TABELA 3 - ANÁLISE QUIMICA DO SOLO FERRALITICO MARROM}

$\begin{array}{ccccccccccccc} & \mathrm{SiO}_{2} & \mathrm{Al}_{2} \mathrm{O}_{3} & \mathrm{Fe}_{2} \mathrm{O}_{3} & \mathrm{FeO} & \mathrm{MnO} & \mathrm{CaO} & \mathrm{Na}_{2} \mathrm{O} & \mathrm{K}_{2} \mathrm{O} & \mathrm{H}_{2} \mathrm{O}^{-} & \mathrm{H}_{2} \mathrm{O}^{+} & \mathrm{CO}^{2+} \\ \text { AMOSTRA } & \% & \% & \% & \% & \% & \% & \% & \% & \% & \% & \% \\ 1 & 6,93 & 6,88 & 57,05 & \text { n.d. } & 2,66 & \text { n.d. } & 0,23 & \text { n.d. } & 2,35 & 10,19 & 0,04 \\ 2 & 4,74 & 22,48 & 52,35 & 4,27 & 0,97 & \text { n.d. } & 0,05 & 0,02 & 0,64 & 2,26 & 0,04\end{array}$

$\begin{array}{rrrrrrrrrrrrrrrrrrr} & \mathrm{Sn} & \mathrm{Mo} & \mathrm{Nb} & \mathrm{Ga} & \mathrm{Sr} & \mathrm{Rb} & \mathrm{Zr} & \mathrm{Ni} & \mathrm{Cr} & \mathrm{TiO} & \mathrm{Y} & \mathrm{Pb} & \mathrm{Zn} & \mathrm{Th} & \mathrm{Cu} \\ & \mathrm{ppm} & \mathrm{ppm} & \mathrm{ppm} & \mathrm{ppm} & \mathrm{ppm} & \mathrm{ppm} & \mathrm{ppm} & \% & \% & \% & \mathrm{ppm} & \mathrm{ppm} & \mathrm{ppm} & \mathrm{ppm} & \mathrm{ppm} \\ 1 & <30 & <10 & 70 & 06 & 13 & 08 & 95 & 0,33 & 8,7 & 3,1 & <10 & <30 & 380 & <50 & <32 \\ 2 & <30 & <10 & 125 & 06 & 21 & 13 & 95 & 0,37 & 6,6 & 3,6 & 10 & <30 & 310 & 300 & <34\end{array}$

n.d. Não detectado

$<$ menos de

\& igual ou menor de 


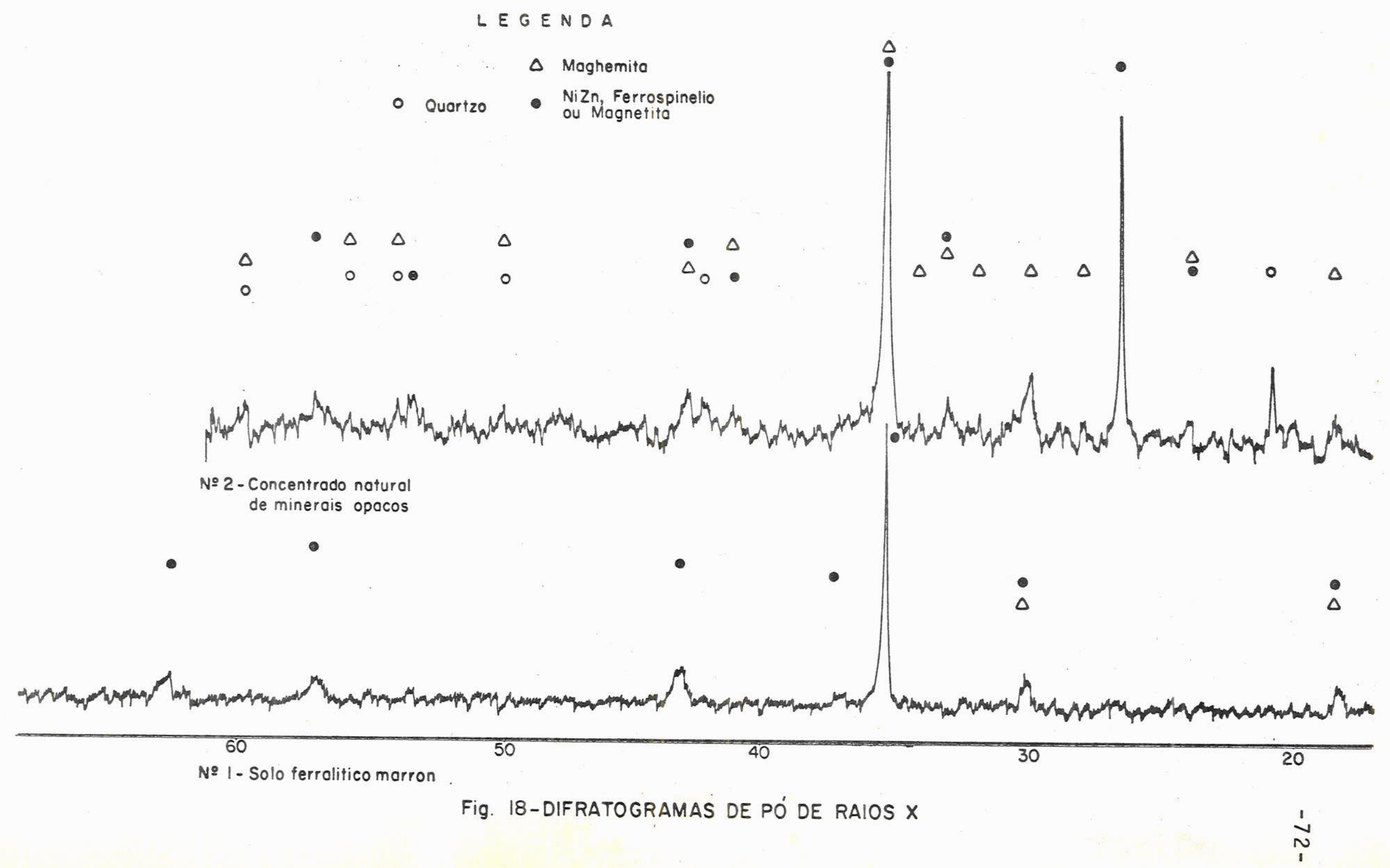


damente, constituindo pisōlitos (Figura 15). Em zonas pla

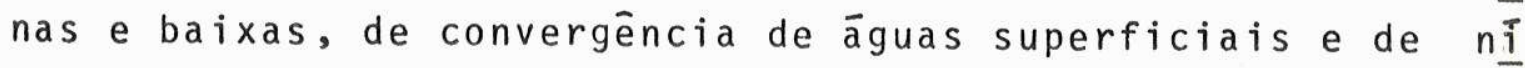
vel freātico raso, formaram-se crostas contīnuas e espessas. onde as crostas são contínuas, na época da chuva o nīvel freātico elevado atinge a superfície e forma correntes inter mitentes.

As concreções são constituĩdas de camadas concên tricas, delgadas, depositadas em torno de um nūcleo algumas vezes diferenciado. A dimensão mēdia dos pisōititos cimenta dos está em torno de $3 \mathrm{~mm}$, variando de 1 a $10 \mathrm{~mm}$. Grãos de ilmenita e cromita são vistos raramente nas seções, estes ū mos costumando apresentar bordos de refletividade maior. pro vavelmente em consequéncia de fatores secundärios de alterá ção que tornam a cromita mais ferrífera (UYTENBOGAARDT, 1951). 0 grau de desidratação dos nūcleos dos pisōlitos é maior, levando à formação de fases intermediārias mais prōximas da hematita, com refletividade maior.

No estudo da concentração dos elementos pela ima gem eletrōnica de microssonda, observa-se a distribuição dó $\mathrm{Cr}, \mathrm{Fe}, \mathrm{Ni}, \mathrm{Ti}, \mathrm{Co}, \mathrm{Al}, \mathrm{Mn}$ e Si nos grãos residuais dos mine rais agregados e nas camadas constituintes das concreções.

Elementos concentrados em grãos de minerais

Mineral

Ilmenita

cromita
$\mathrm{Ti}$

$\mathrm{Cr}, \mathrm{Co}, \mathrm{Ti}, \mathrm{Al}$ lemento
Elementos dispersos nas camadas concēntricas:

E interessante notar a concentração de $\mathrm{Cr}$ na ilme 


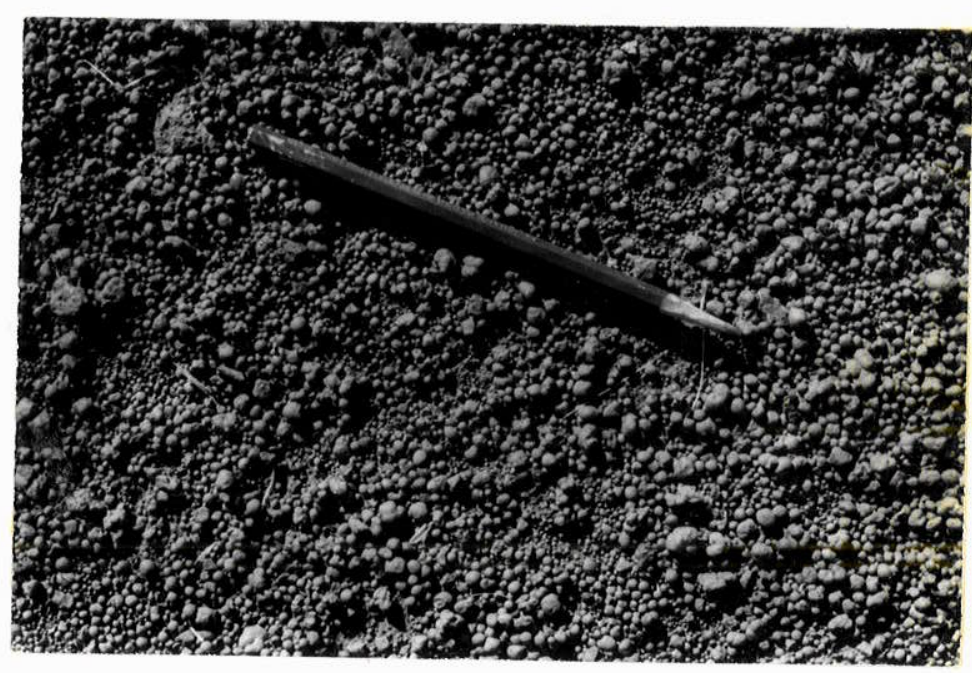

Foto 25 - Foto de concreções pisolíticas soltas no solo 


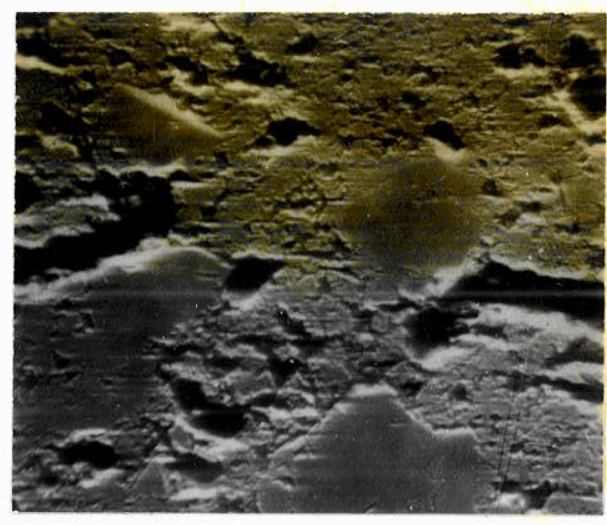

Seção B-1, comp. $150 x$

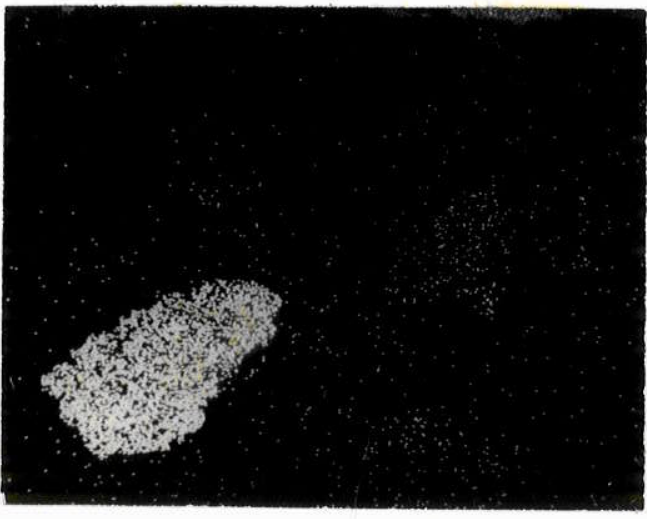

Seção $B-2, T i(K \alpha)$

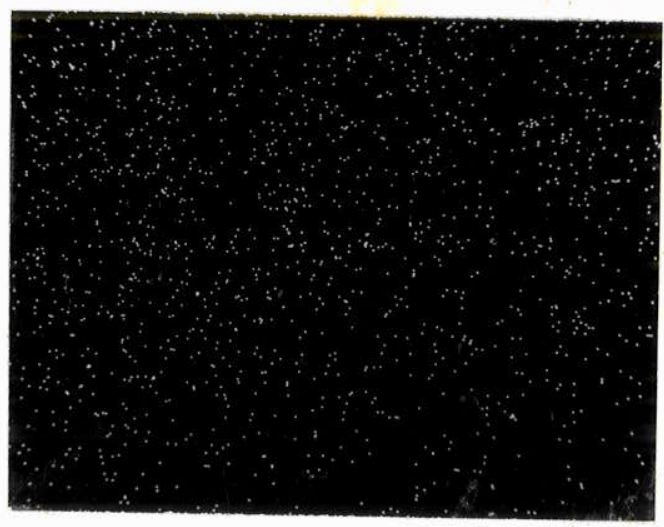

Seção B-4, Co $(K \alpha)$

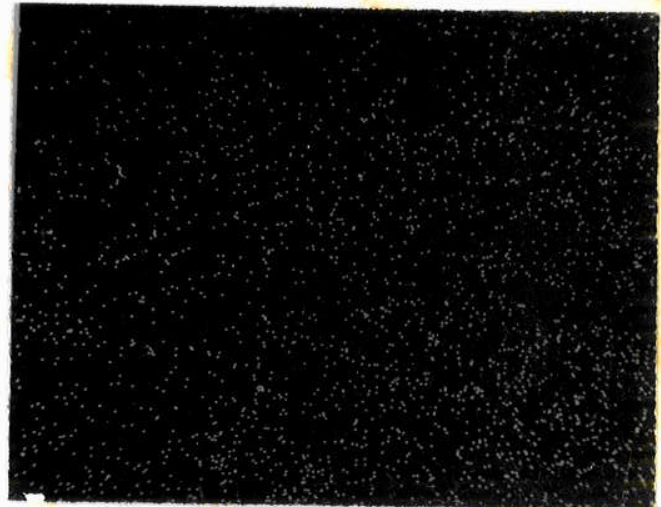

Seção $B-3, N i(K \alpha)$

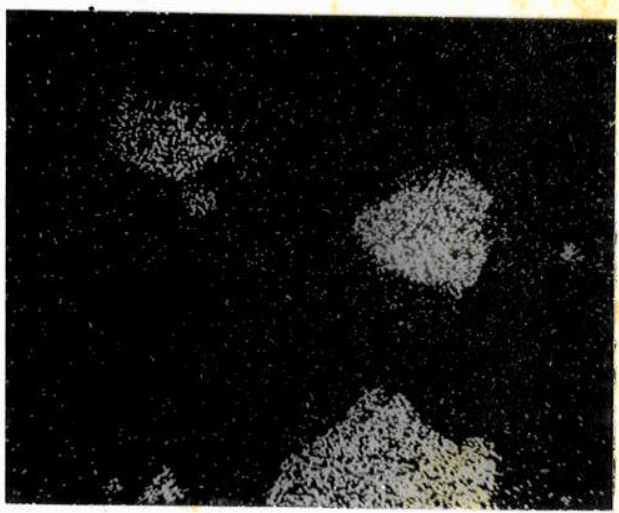

Seção B-5, $\operatorname{Cr}(K \alpha)$

Foto 26, B-1 a B-5 - Micrografia eletrōnica e microssondaElementos $\mathrm{Ni}$ e Co dispersos, respectivamente, nas seções B-3 e B-4. Na seção B-2, cristal de ilmenita. Seção B-5 com cristais de cromita. Notar que onde ocorre cromita (B-5) a porcentagem de $\mathrm{Ti}(\mathrm{B}-2) \overline{\mathrm{e}}$ elevada.Para identificação completa da ilmenita e cromita, ver Capítulo IX. 


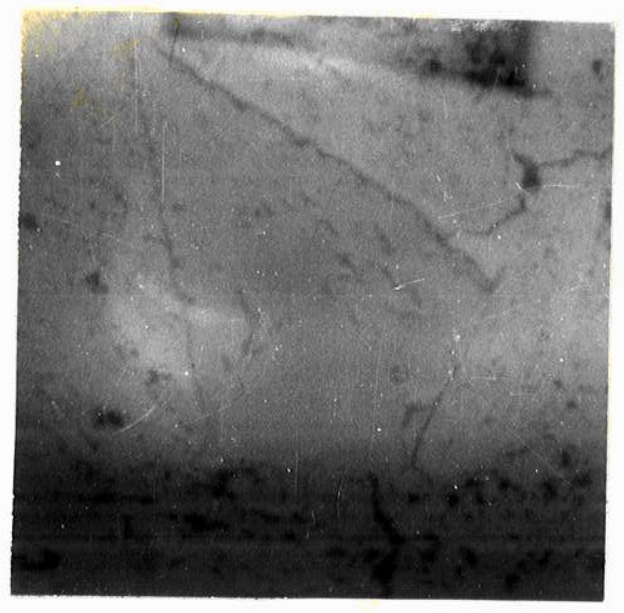

Seção C-1, Comp. $600 x$

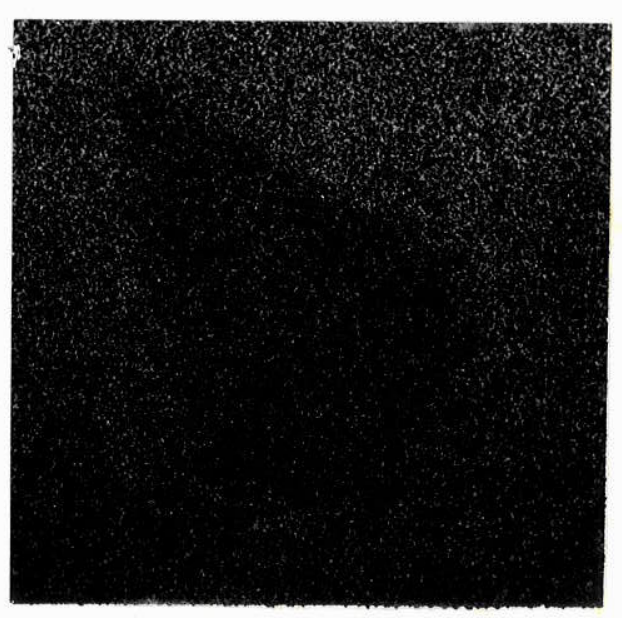

Seção C-3, $\mathrm{Fe}(\mathrm{K} \alpha)$

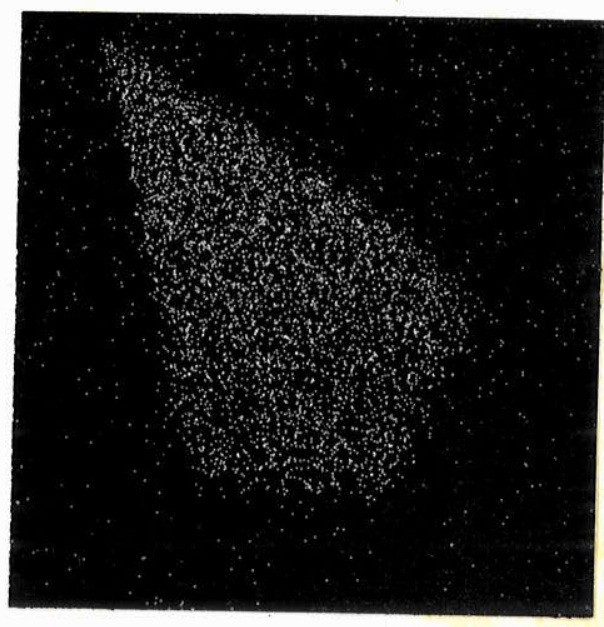

Seção $C-2, \operatorname{Cr}(K \alpha)$

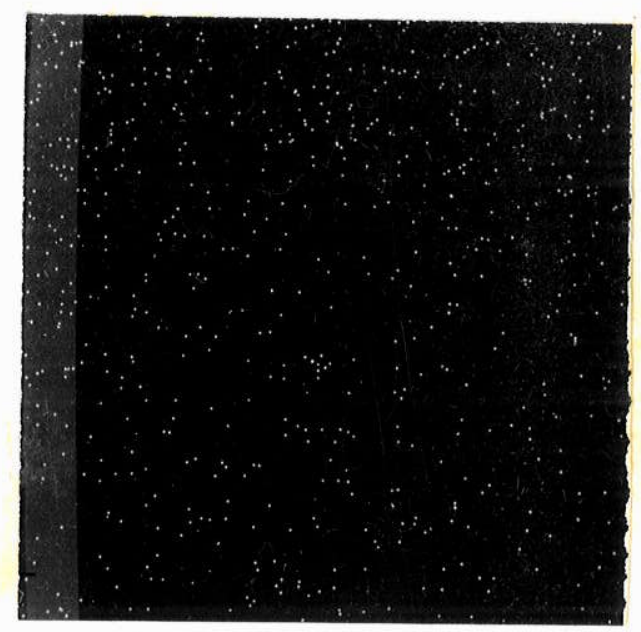

Seção $C-4, N i(K \alpha)$ 


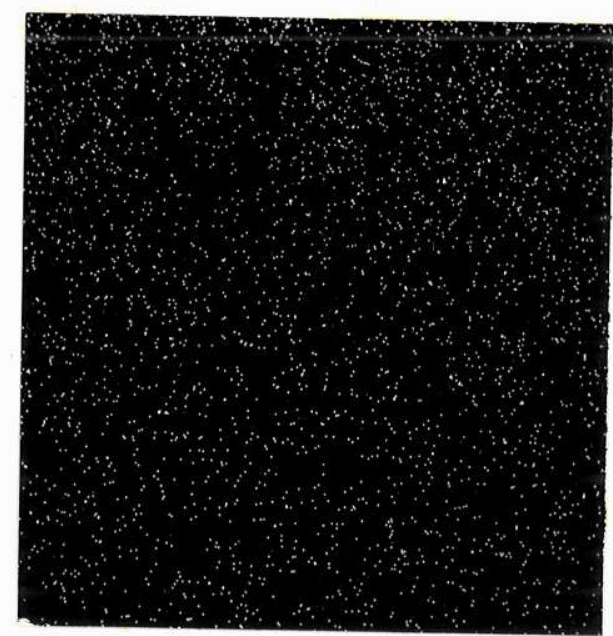

Seção $C-5, \operatorname{si}(K \alpha)$

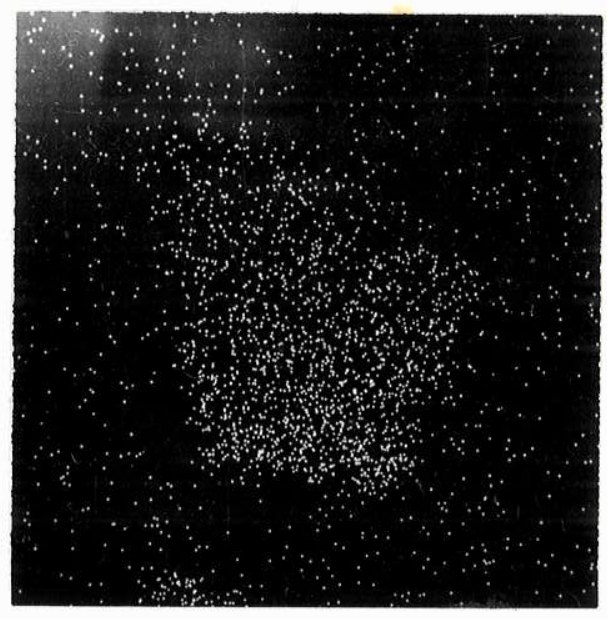

Seção $C-7, \operatorname{Co}(K \alpha)$

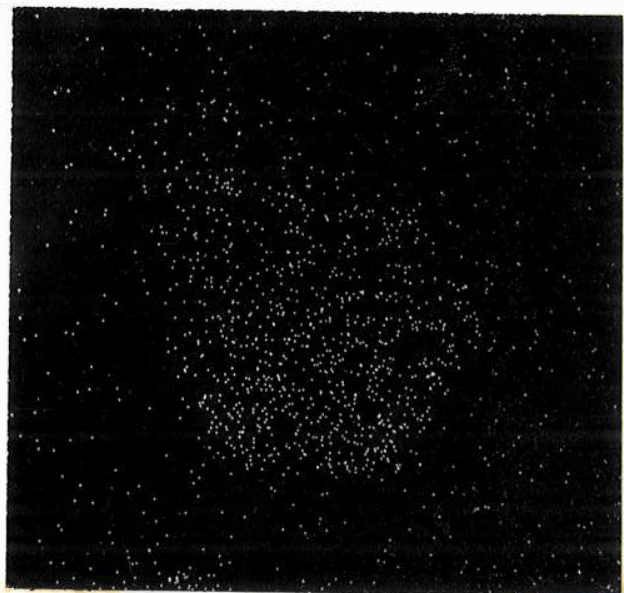

Seção $C-6, A 1(K \alpha)$

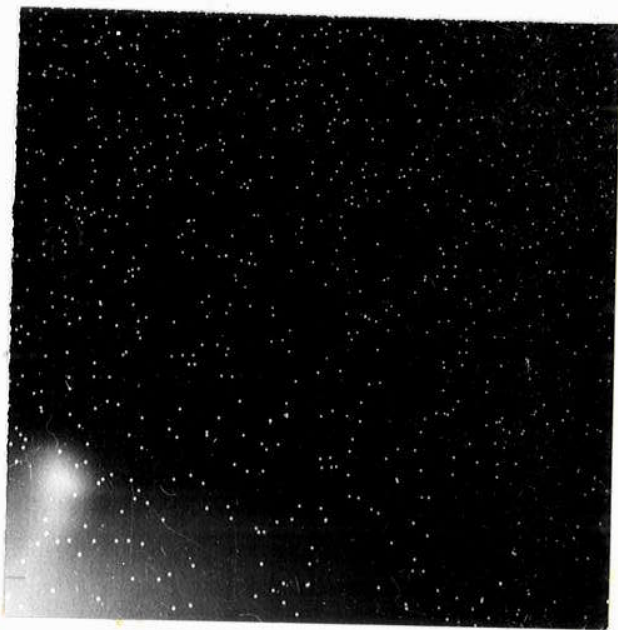

Seção $C-8, M n(K \alpha)$

Foto 27 - C-1 a C-8 - Micrografia e microssonda. A distribuição do Cr, Al e Co é preferencial. Deve corresponder a um cristal de cromita, em cuja fórmula é admitido também Al. O Fe compensa negativamente o $\mathrm{Cr}$; $\mathrm{Ni}, \mathrm{Si}$ e $\mathrm{Mn}$ estão dispersos homogêneamente na seção. 


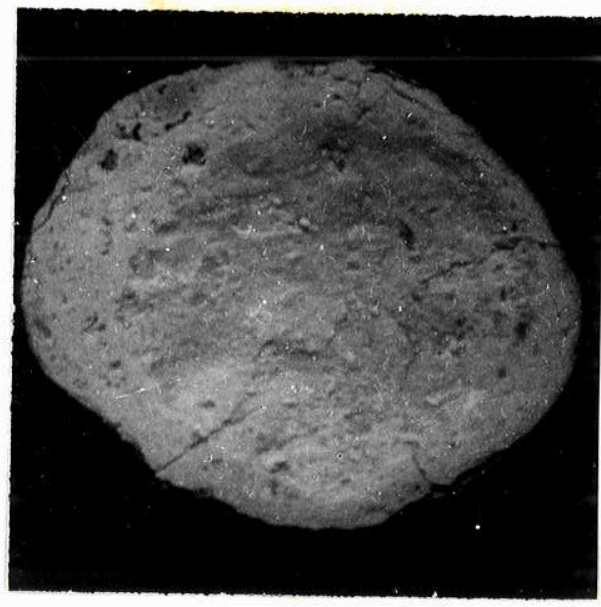

Seção D-1 - Comp.300X

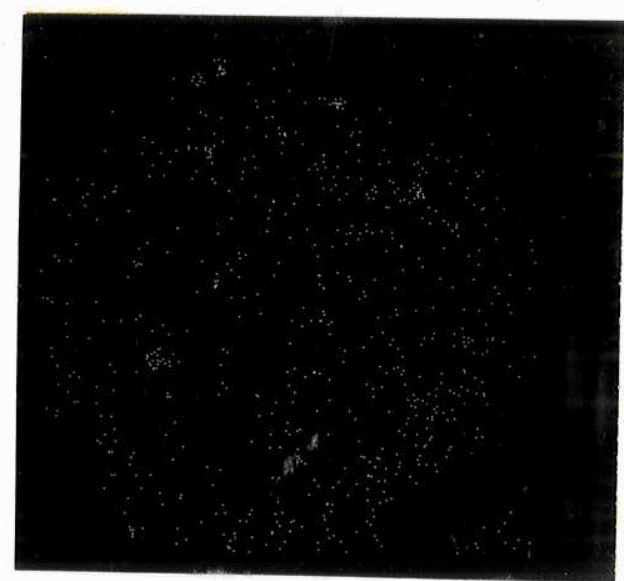

Seção $D-3, C r(K \alpha)$

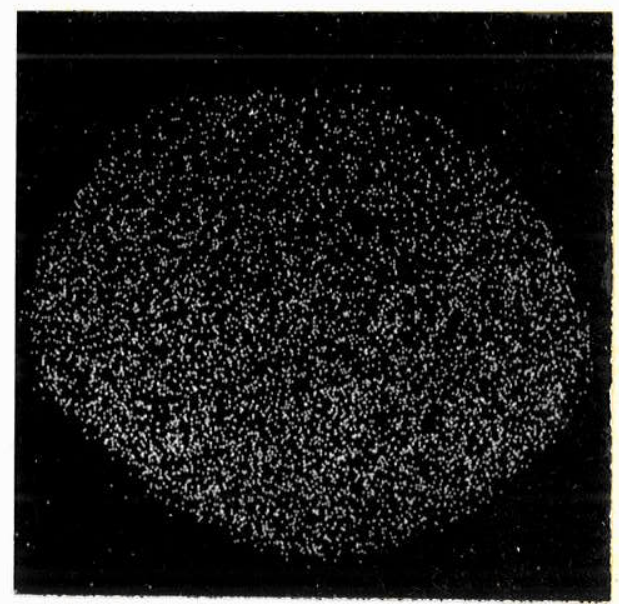

$$
\text { Seção } D-2, \operatorname{Fe}(K \alpha)
$$

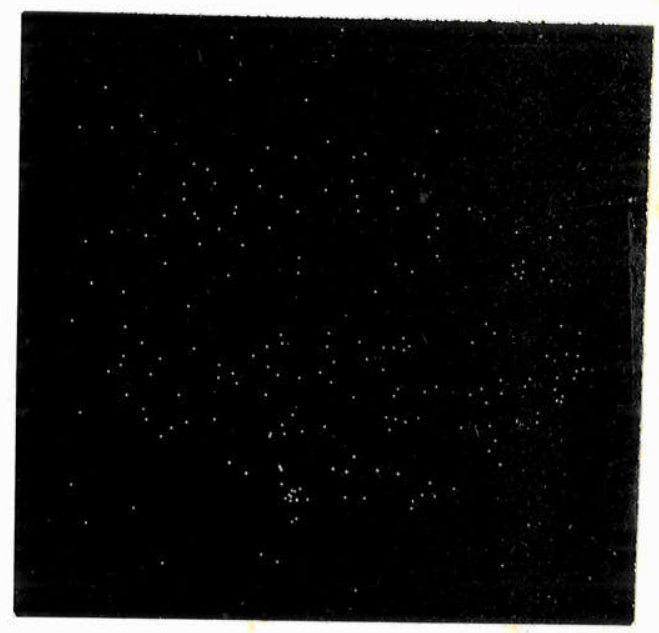

Seção $D-4, N i(K \alpha)$

Foto 28 - D-1 a D-4 - Micrografia eletrônica e microssonda. $\mathrm{Fe}, \mathrm{Cr}$ e $\mathrm{Ni}$ estão dispersos, sem distribuição preferencial na composição, indicando um cimento homogéneo, se bem que heterogēneo no aspecto físico. $0 \mathrm{Cr}$ apresenta-se levemente concentrado em alguns pontos, mas não chega a caracterizar a presença de cromita agregada na concreção. 
nita e de Co na cromita, se bem que em porcentagem baixa em relação ao elemento ou elementos principais. Por outro lado, na coluna da direita, verifica-se que todos os elementos de tectados pela microssonda podem estar dispersos nas concre ções pisoliticas.

VIII.III - DISTRIBUIÇÃO DO $\mathrm{Ni}, \mathrm{Fe}, \mathrm{MgO}, \mathrm{Cr}$ e Co

Neste capĩtulo serão feitas considerações a respei to da distribuição de alguns elementos analisados em amos tras de poços abertos na ārea de pesquisa numa malha variā vel de 50 a 200 m. 0 estudo da distribuição vertical média dos elementos conduziu a algumas observações a respeito do comportamento e distribuição de acordo com a litologia e to pografia locais. Amostras localizadas em zonas de dunitos, peridotitos e piroxenitos foram agrupadas, pois, de acordo com a topografia local e a profundidade, cujas anālises es tão representadas na Tabela 4. A amostragem levada a efei to pela Companhia é do tipo calha, coletada na parede de pó ços cuja profundidade chegou a atingir atē $15 \mathrm{~m}$. Cada amos tra representa um segmento de $1 \mathrm{~m}$, desde a boca do poço até sua profundidade máxima limitada pela impossibilidade de frag mentar a rocha ou, então, pelo fato de atingir o nível hị drostātico. Desse modo, os poços são interrompidos, em ge ral, em ultramāfica coesa, pouco alterada, com teores baixos de $\mathrm{Ni}$, portanto, sem interesse económico imediato.

os gräficos mostram as curvas de teores de cada elemento, separadas para cada tipo de rocha. E forçoso lem brar que as anālises quīmicas são de rochas totais coletadas sem uma separação dos nỉveis do perfil de alteração. Entretan to, como são centenas de amostras, elas são representativas 
TABELA 4 - NOMERO DE AMOSTRAS COLETADAS SEGUNDO A LITOLOGIA E A TOPOGRAFIA

\begin{tabular}{|c|c|c|c|c|c|c|c|c|c|c|}
\hline & & AREA & PLANA & & & & TOPO & OU ENC & STA DE N & MORRO \\
\hline \multirow[t]{6}{*}{ ROCHA } & PROFUNDIDADE (m) & $\mathrm{Ni}$ & $\mathrm{MgO}$ & $\mathrm{Fe}$ & $\mathrm{Cr}$ & Co & $\mathrm{Ni}$ & $\mathrm{MgO}$ & $\mathrm{Fe}$ & $\mathrm{Cr}$ \\
\hline & $0-1$ & 28 & 22 & 22 & 22 & - & 3 & 3 & 3 & 3 \\
\hline & $1-2$ & 28 & 22 & 22 & 22 & - & 3 & 3 & 3 & 3 \\
\hline & $2-3$ & 26 & 21 & 21 & 21 & - & 3 & 3 & 3 & 3 \\
\hline & $3-4$ & 25 & 20 & 20 & 20 & - & 3 & 3 & 3 & 3 \\
\hline & $4-5$ & 23 & 19 & 19 & 19 & - & 3 & 3 & 3 & 3 \\
\hline \multirow{4}{*}{ PIROXENITO } & $5-6$ & 21 & 17 & 17 & 17 & - & 3 & 3 & 3 & 3 \\
\hline & $6-7$ & 22 & 17 & 17 & 17 & - & 3 & 3 & 3 & 3 \\
\hline & $7-8$ & 17 & 13 & 13 & 13 & - & 3 & 3 & 3 & 3 \\
\hline & $8-9$ & 17 & 12 & 12 & 12 & - & 3 & 3 & 3 & 3 \\
\hline & $9-10$ & 12 & 6 & 6 & 6 & - & 3 & 3 & 3 & 3 \\
\hline & $10-11$ & 2 & 2 & 2 & 2 & - & 2 & 2 & 2 & 2 \\
\hline & $11-12$ & 1 & 1 & 1 & 1 & - & - & - & - & - \\
\hline & Totais & 222 & 172 & 172 & 172 & - & 32 & 32 & 32 & 32 \\
\hline & $0-1$ & 16 & 6 & 6 & 12 & - & 1 & 1 & 1 & 1 \\
\hline & $1-2$ & 16 & 12 & 12 & 12 & - & 1 & 1 & 1 & 1 \\
\hline & $2-3$ & 15 & 12 & 12 & 12 & - & 1 & 1 & 1 & 1 \\
\hline & $3-4$ & 16 & 12 & 12 & 12 & - & 1 & 1 & 1 & 1 \\
\hline \multirow[t]{11}{*}{ PERIDOTITO } & $4-5$ & 15 & 11 & 10 & 10 & - & 1 & 1 & 1 & 1 \\
\hline & $5-6$ & 16 & 11 & 11 & 11 & - & 1 & 1 & 1 & 1 \\
\hline & $6-7$ & 13 & 10 & 10 & 10 & - & 1 & 1 & 1 & 1 \\
\hline & $7-8$ & 9 & 7 & 7 & 7 & - & 1 & 1 & 1 & 1 \\
\hline & $8-9$ & 7 & 5 & 5 & 5 & - & 1 & 1 & 1 & 1 \\
\hline & $9-10$ & 8 & 8 & 8 & 8 & - & 1 & 1 & 1 & 1 \\
\hline & Totais & 131 & 94 & 93 & 99 & - & 10 & 10 & 10 & 10 \\
\hline & $0-1$ & 66 & 32 & 33 & 36 & 9 & 35 & 24 & 24 & 29 \\
\hline & $1-2$ & 71 & 32 & 32 & 36 & 9 & 30 & 22 & 22 & 24 \\
\hline & $2-3$ & 65 & 28 & 29 & 31 & 9 & 19 & 13 & 13 & 15 \\
\hline & $3-4$ & 62 & 26 & 26 & 25 & 9 & 14 & 9 & 9 & 9 \\
\hline \multirow[t]{8}{*}{ DUNITO } & $4-5$ & 46 & 17 & 16 & 15 & 10 & 8 & 5 & 5 & 5 \\
\hline & $5-6$ & 30 & 13 & 13 & 13 & 9 & 6 & . & 2 & 3 \\
\hline & $6-7$ & 21 & 7 & 7 & 7 & 4 & 5 & 3 & 2 & 3 \\
\hline & $7-8$ & 13 & 5 & 5 & 5 & 4 & 5 & 2 & 2 & 2 \\
\hline & $8-9$ & 5 & 2 & 2 & 2 & 1 & - & - & - & - \\
\hline & $9-10$ & 4 & 2 & 2 & 2 & 2 & - & - & - & - \\
\hline & Totais & 383 & 163 & 165 & 172 & 66 & 122 & 81 & 79 & 91 \\
\hline & $\begin{array}{c}\text { TOTAL GERAL } \\
2.644\end{array}$ & 736 & 429 & 430 & 443 & 66 & 164 & 123 & 121 & 133 \\
\hline
\end{tabular}


Fig.19-DISTRIBUIÇÃO dO Ni E Co EM ÁREAS PLANAS

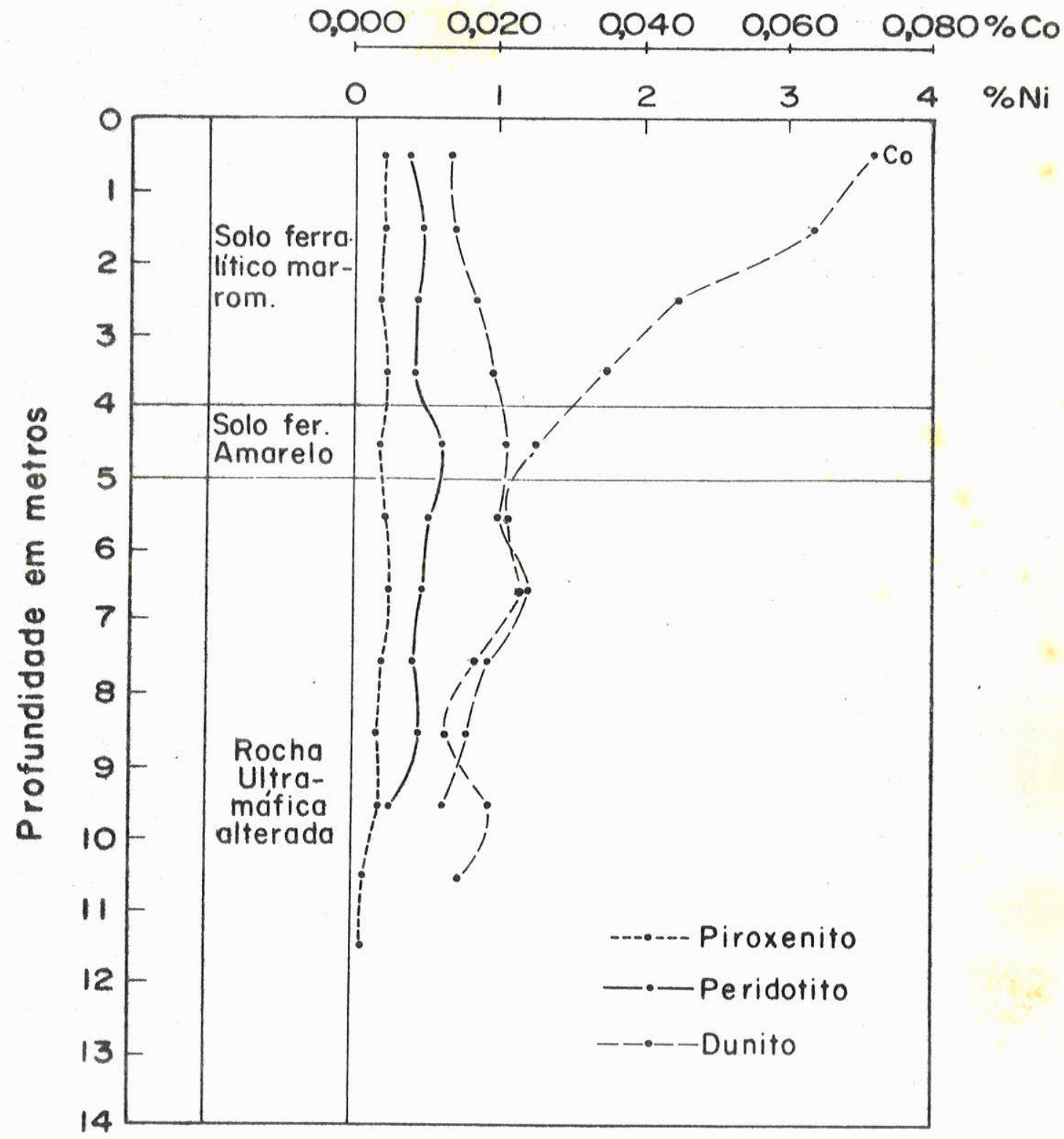


FIg.2O.DISTRIBUIÇÃO DO NI EM ÁREAS DE TÔPO OU ENCOSTA DE MORRO

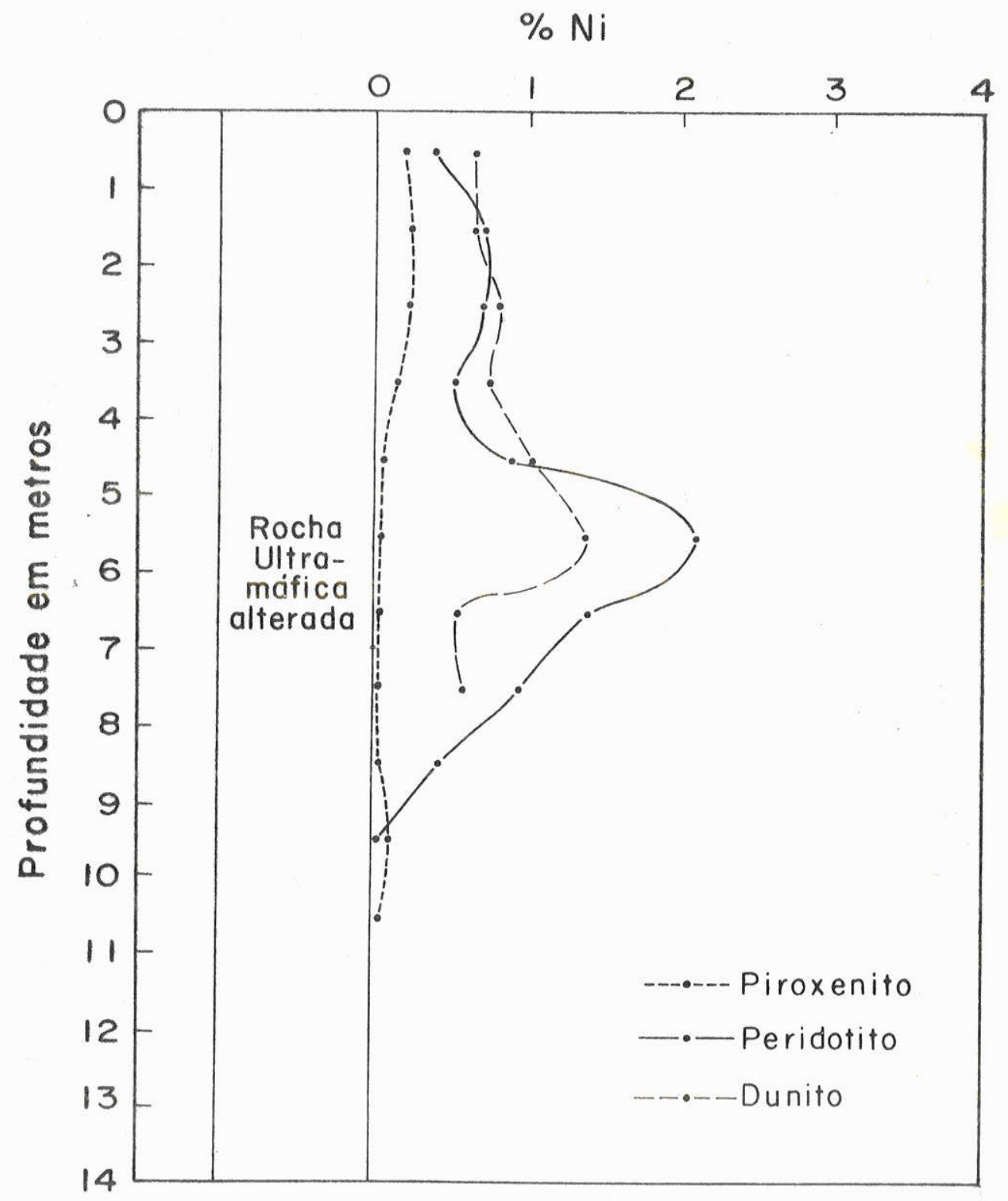


de certos aspectos da distribuição dos elementos analisados.

Inicialmente, o comportamento dos elementos de zo nas baixas, planas, cobertas por solo ferralitico marrom, constituído de material "in situ" e transportado das encos tas e morros prōximos será comparado com os mesmos elementos de āreas de topo ou encosta de morros. Não foi feita uma se paração entre o topo dos morros e as vertentes, pelo fato de não terem sido encontrados platôs com continuidade horizon ta1. Os morros são em espigões em linhas de cumeadas ou iso lados com formas arredondadas. Apenas um local do distrito apresenta um pequeno platō, capeado por uma crosta de calce dônea, local este denominado Morro do Caiçara (Mapa da Figu ra 3).

0s limites entre o "solo ferralitico marrom", o "solo ferralítico amarelo" e a "rocha ultramāfica alterada" são determinados por valores médios obtidos a partir de vá rias centenas de medidas. Quase todos os perfis elaborados em zonas baixas, planas, contêm estes horizontes.

\section{Distribuição dos elementos $\mathrm{Ni}$ e Co}

Das três rochas analisadas e representadas na Figu ra 19, o teor de $\mathrm{Ni}$ é mais alto no dunito, médio no peridoti to e baixo no piroxenito. No dunito os teores de Ni crescem da superfīcie atē $7 \mathrm{~m}$ de profundidade, atingindo valores me dios superiores a $1 \%$. Abaixo daquela profundidade o teor decresce paulatinamente. No peridotito a concentração de $\mathrm{Ni}$ aumenta da superfície atē $5 \mathrm{~m}$, decrescendo em seguida. Os piroxenitos mostram teores relativamente baixos ao longo do perfil, com um sensível decrēscimo em torno de $11 \mathrm{~m}$. Apesar da garnierita não ser visĩvel no solo ferralitico marrom e amarelo, supõe-se que o $\mathrm{Ni}$ esteja associado, pelo menos em parte, à goethita, segundo caracterizado por COMBES (1963). 
0 cobalto por sua vez apresenta concentração rela tivamente alta na zona superficial. E um elemento bastante solūvel, concentrando-se na zona imediatamente superior do perfil e decrescendo paulatinamente com a profundidade.

Na Figura 20, que representa o perfil de distribui ção do $\mathrm{Ni}$ emáreas de topo ou encosta de morro, com circulá ção mais fäcil de āgua subterrānea, devido à posição topogrā fica elevada o $\mathrm{Ni}$ concentra-se nos dunitos, atingindo valores superiores a $1 \%$ de 4 a $5 \mathrm{~m}$ atē 6 a $7 \mathrm{~m}$ de profundidade. № ta-se que este elemento segue o abaixamento da frente de a 1 teração, sendo remobilizado da zona superficial e concentra do a valores maiores entre 5 e $6 \mathrm{~m}$. Em outras palavras, a sua distribuição em āreas planas tem maior dispersão verti cal e menor concentração, dando-se o inverso nos perfis de topo e encosta de morros. Assim, pode-se inferir que em zo nas planas as reservas de $\mathrm{Ni}$ são maiores, a despeito de um teor māximo mēdio menor. Neste particular, entretanto, de ve-se considerar a representatividade geogrāfica de cada uma das āreas.

Os valores obtidos para o peridotito seguem esque ma semelhante, mas não serão comentados pelo fato de cada pon to ser representado por apenas uma anālise quỉmica.

$0 \mathrm{Ni}$ nos piroxenitos mantēm-se com valores extrema mente baixos.

Comparando-se os dois perfis, verifica-se que o $\mathrm{Ni}$ tem uma distribuição mais homogēnea nas äreas planas que nas encostas de morros, onde depende de fluxos de āgua de infil tração menos constantes e mais direcionais, condicionados às irregularidades e tendências topogräficas. 


\section{Distribuição do elemento Fe}

0 Fe estā presente na olivina e em vārios minerais opacos disseminados nas ultramāficas. Consequentemente, as anālises químicas de solo e rocha alterada incluem Fe das olivinas residuais, das serpentinas, de minerais opacos e Fe solubilizado e precipitado ao longo do perfil na forma de oxidos e hidrōxidos.

Comparando-se os perfis das äreas planas (Figura 21) com os das de topo ou encosta de morro(Figura 22), nota-se que os teores de Fe total nas primeiras são superiores e mais homogêneos atē a profundidade de $8 \mathrm{~m}$, a partir de onde tor nam-se prōximos nos dois tipos de āreas. Mais uma vez é for çoso lembrar que o perfil do peridotito não serā considerá do, pelo fato de vārios pontos serem representados apenas por uma anālise química (Tabela 4). Nota-se uma porcenta gem menor de $\mathrm{Fe}$ no primeiro segmento de um metro do perfil de áreas de topo ou encosta de morro, que corresponde a ser pentinito alterado. Atē a profundidade aproximada de $5 \mathrm{~m} \overline{\bar{e}}$ explicāvel que o Fe mantenha uma mëdia superior, desde que corresponda aos níveis de solo ferralítico marrom e amarelo; contudo, abaixo deste valor, atē $7 \mathrm{~m}$, nota-se um enriquecimen to maior do elemento Fe. No traçado geral, observa-se que o Fe é residual e acumulativo, decrescendo vagarosamente a partir do topo do perfil. os maiores teores superficiais advêm da facilidade com que ele se oxida. Conforme pode se verificar no capitulo "MINERAIS OPACOS", o Fe quantificado pelas anālises quỉmicas provēm primariamente da olivina, ser pentina, magnetita, ilmenita, cromita, magnetita titanifera e a partir de minerais secundārios, como a hematita, maghemi ta e goethita. Minerais amorfos e hidratados devem estar presentes no perfil, mas não foram estudados. 
Fig.21-DISTRIBUIÇÃO DO Fe EM ÁREAS PLANAS

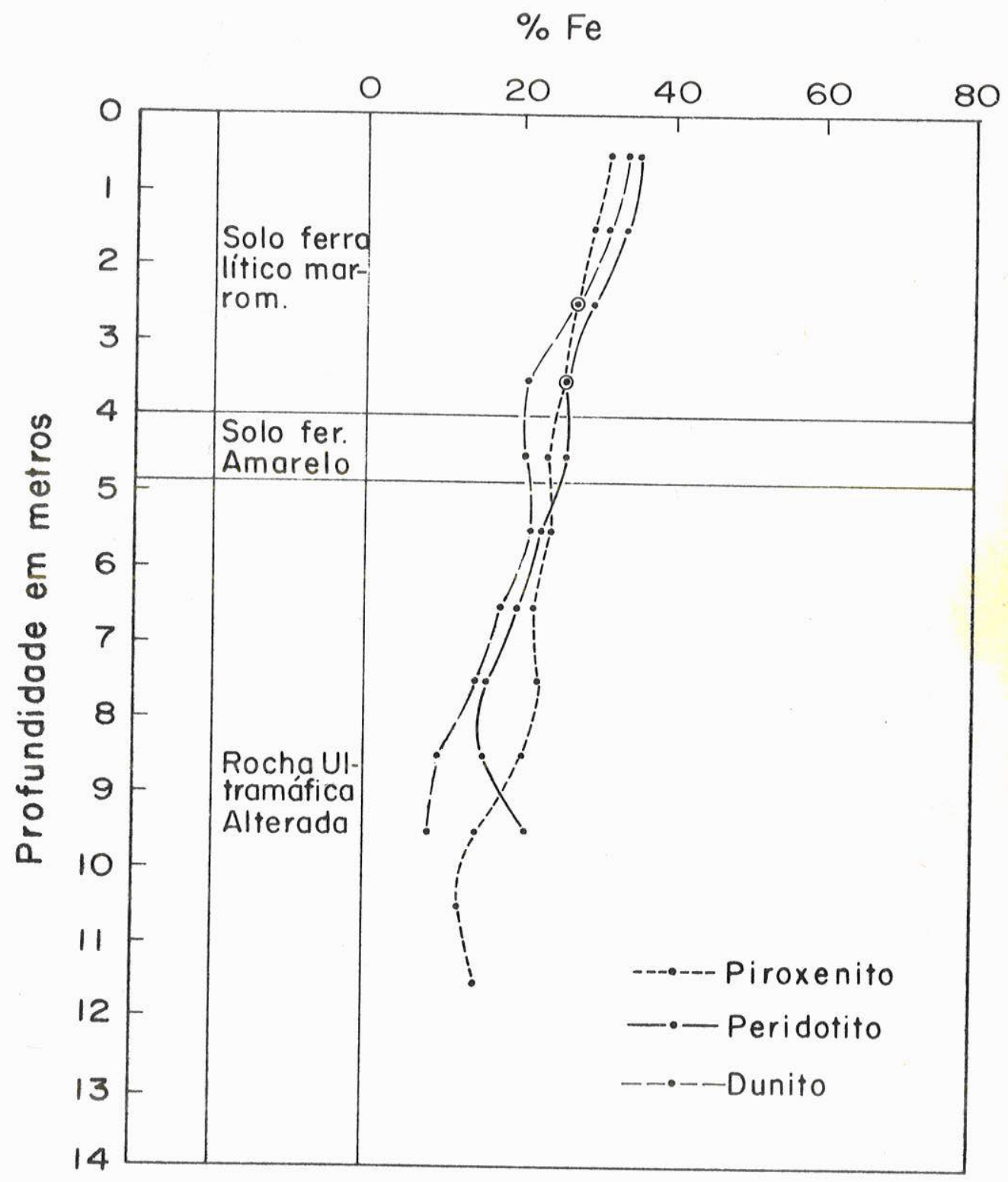


Fig.22-DISTRIBUIÇÃO DO Fe EM ÁREAS DE TÔPO OU ENCOSTA DE MORRO

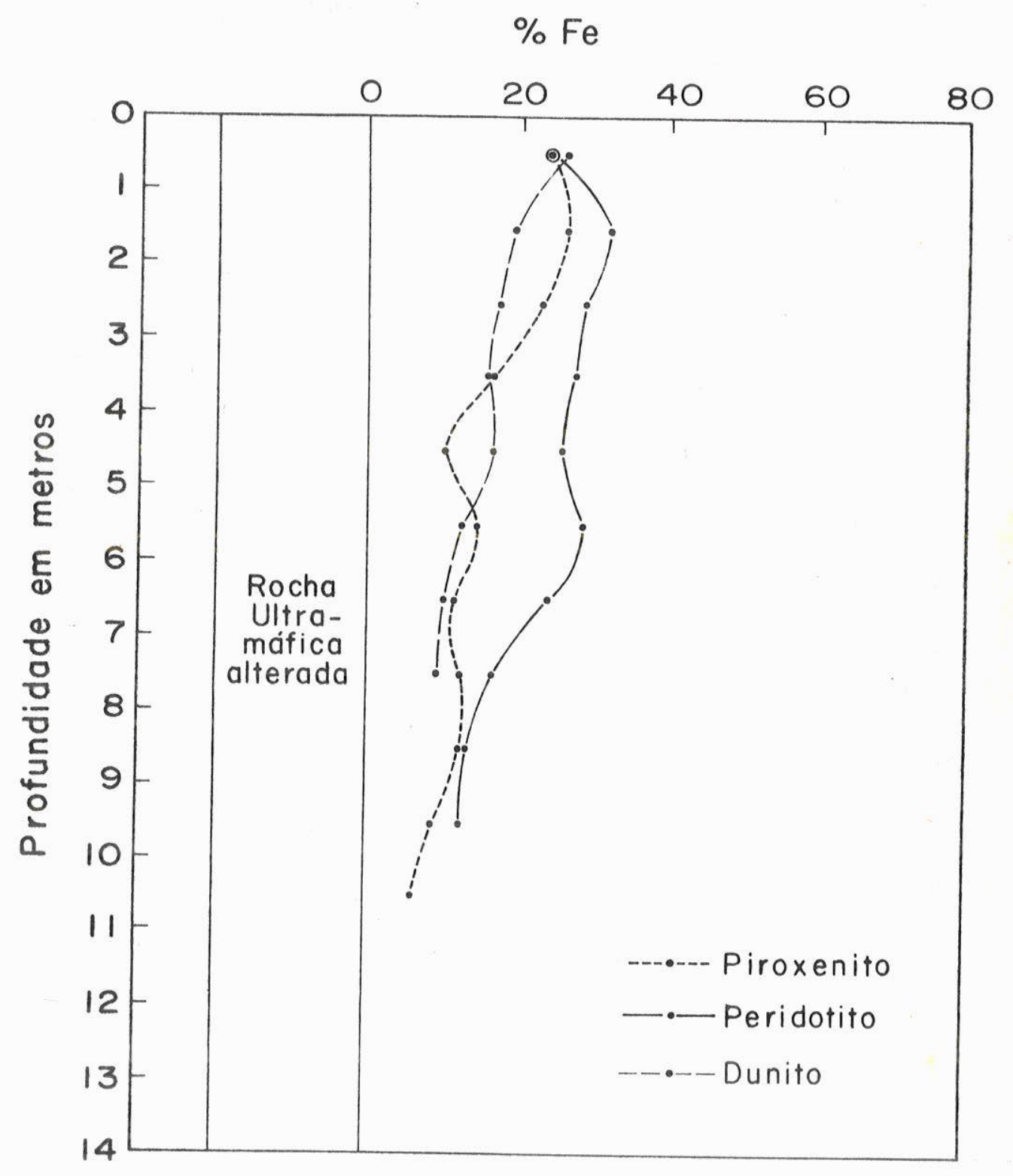




\section{Distribuição do Mg0}

Os teores de MgO nos dunitos são visivelmente mais elevados que nos peridotitos e piroxenitos, tanto na zona su perficial quanto em profundidade (Figuras 23 e 24 ). De to dos os elementos analisados, o Mgo è o mais solūvel, sendo lixiviado com grande facilidade no topo do perfil e carreado pelas āguas de infiltração.

E interessante notar que a porcentagem de $\mathrm{MgO}$ no solo ferralítico de zonas planas equivale, em mēdia, à por centagem de Mg0 do serpentinito lixiviado em encostas de morros. Este comportamento confirma o carāter extremamente solüvel deste elemento.

\section{Distribuição do Cr}

0 elemento $\mathrm{Cr}$ estā presente na cromita, mineral considerado como tipicamente residual. Estā disseminado ou constituindo delgadas vēnulas na rocha ultramāfica.

No perfil da figura correspondente às āreas planas (Figura 25), os teores de $C r$ são muito mais altos, possivel mente devido à atuação dos processos mecānicos de concentrá ção que carreiam cromita das encostas dos morros para o solo ferralitico das zonas planas. Abaixo da zona de concentra ção mecânica, a cromita é enriquecida relativamente pela $1 \underline{i}$ xiviação dos demais componentes da rocha.

E oportuno lembrar que vārias dezenas de poços fo ram considerados, alguns com solos ferraliticos mais espes sos, outros mais delgados, podendo ampliar para cima ou para baixo os limites de acumulação mecânica.

Em āreas planas e atē a profundidade de $3 \mathrm{~m}$, duni tos possuem teores nitidamente mais elevados de $\mathrm{Cr}$ que peri dotitos e piroxenitos. 
Fig.23.DISTRIBUIÇÃO DO MgO EM ÁREAS PLANAS

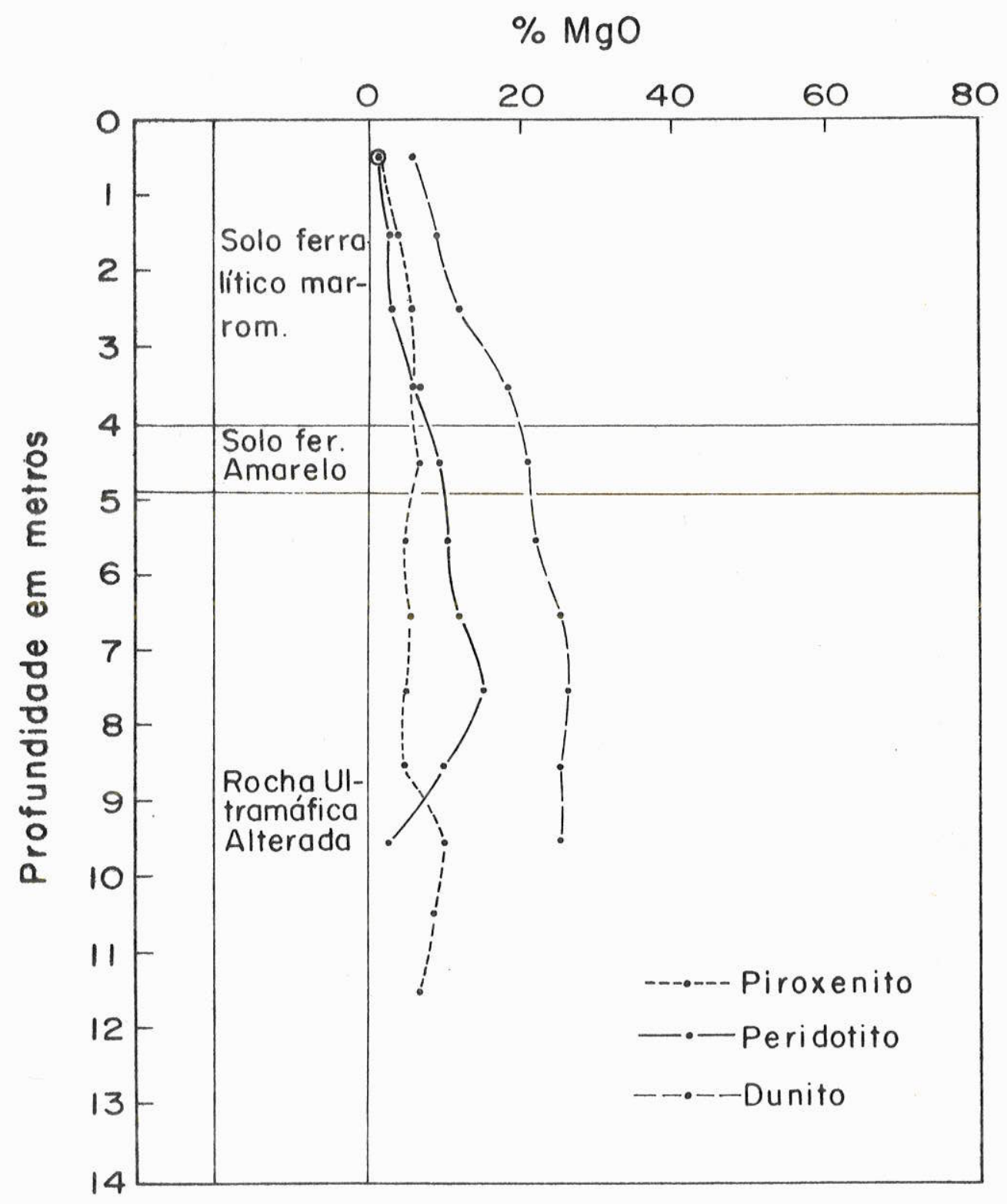


Fig.24.DISTRIBUIÇÃO DO MgO EM ÁREAS DE TÔPO OU ENCOSTA DE MORRO

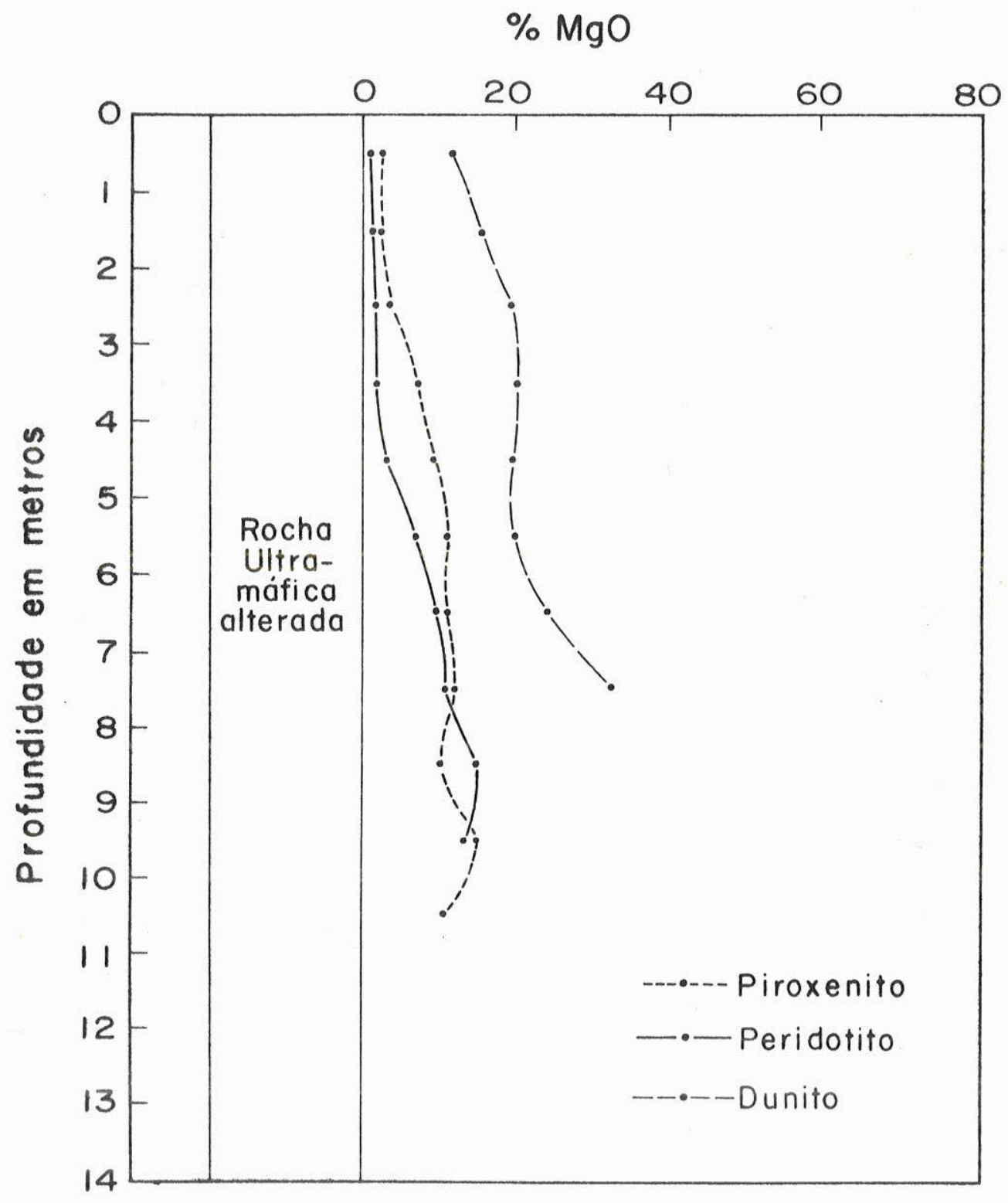


FIg.25-DISTRIBUIÇÃO DO Cr EM ÁREAS PLANAS

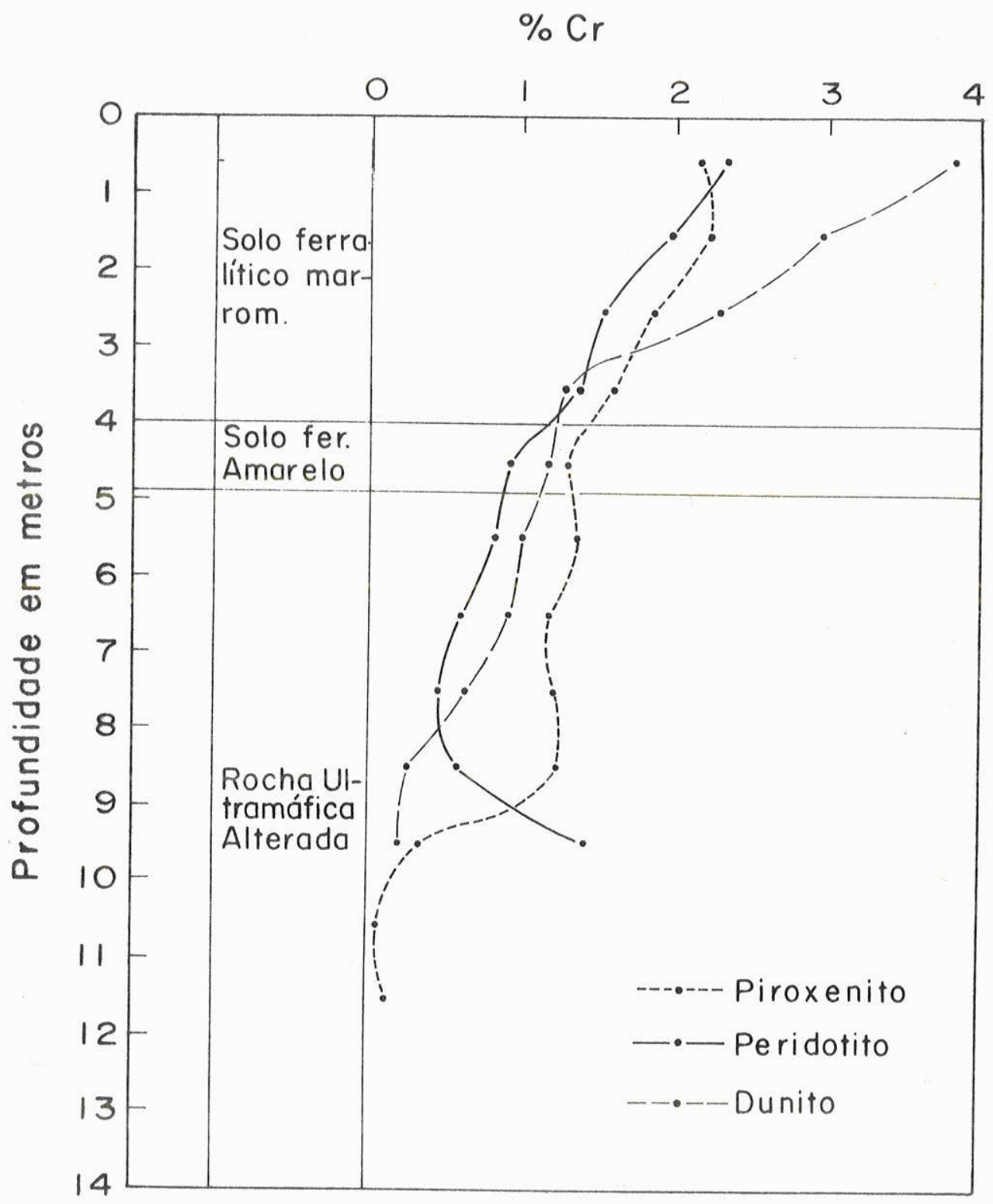


FIg.26-DISTRIBUIÇÃO DO Cr EM ÁREAS DE TÔPO OU ENCOSTA DE MORRO

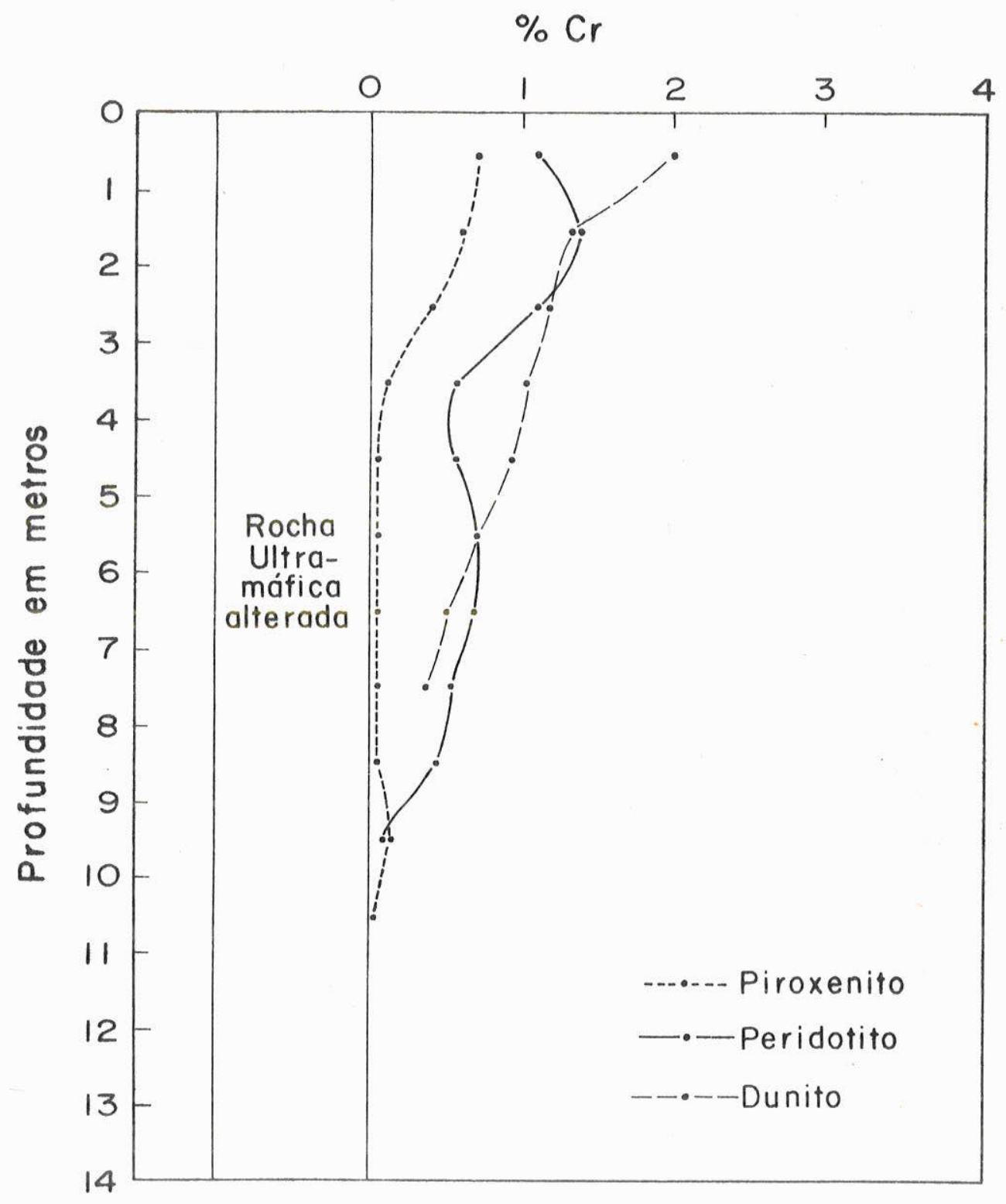




\section{CAPITULO IX}

\section{MINERAIS SINGENETICOS E EPIGENETICOS}

Os minerais constituintes do solo e das rochas al teradas "in situ" podem ter origem primāria, ter sido forma dos por alteração hidrotermal e, finalmente, podem ter se originado pela ação dos processos intempēricos. Estes ūiti mos são de fácil identificação; entretanto, os primeiros as sociam-se tão intimamente nos agregados e apresentam dimen sões tão pequenas que sua separação è praticamente imposs vel. Em face destas dificuldades, estes minerais serão de critos juntos em um mesmo capitulo. Os agregados de opacos foram separados de acordo com o grau de magnetismo,descritos em sua mineralogia e submetidos a algumas anālises quỉmicas, de modo a verificar a proporção dos elementos maiores e/ou. detetar elementos raros.

\section{IX.I - VERMICULITA}

Mineral comum na ārea da ultramāfica, em veios de distribuição errātica e sem continuidade horizontal ou verti cal. Algumas zonas preferenciais do distrito são cortadas por dezenas de veios, com maior ou menor proximidade geogrā fica.

0corre de duas maneiras distintas no distrito de Santa Fé. A primeira, de granulação fina, sub-milimétrica, 
$-94-$

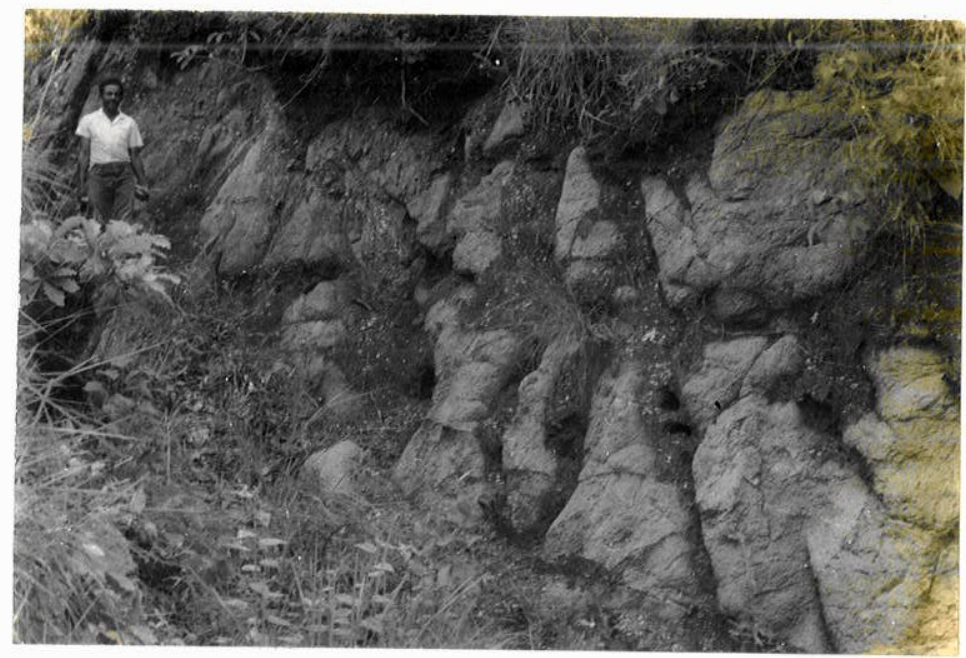

Foto 29 - Controle estrutural dos veios de vermiculita fina. Rocha encaixante é um dunito. Morro do Tirapressa.

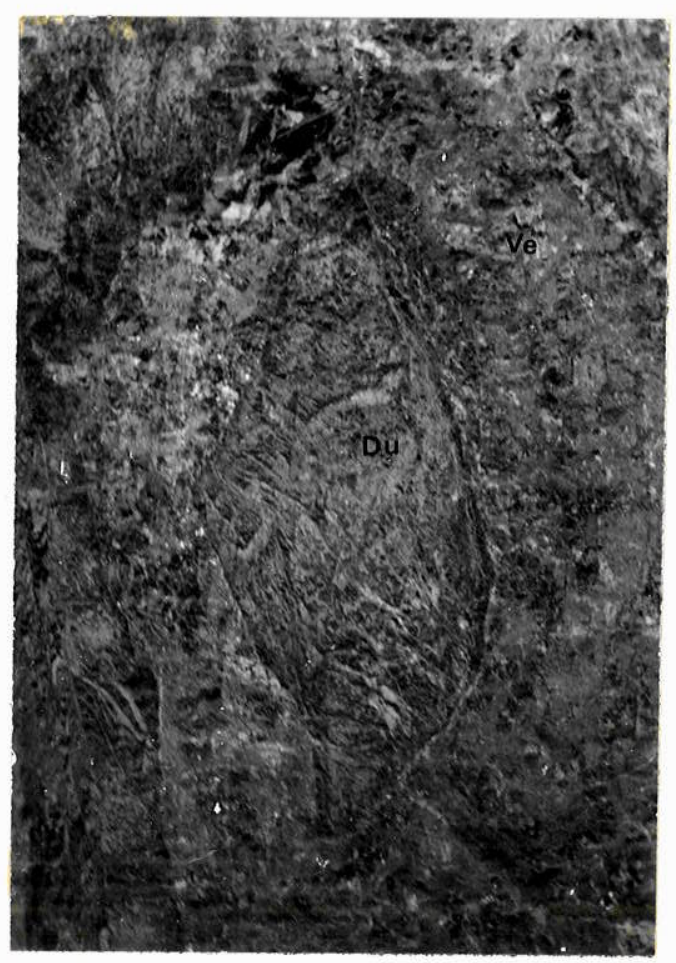

Foto 30 - "Xenōlito" de dunito (Du) dentro de um veio de vermiculita(Ve) fina. Região Sul do Tirapressa. 
formada pela alteração das rochas ultramāficas, disseminada ou, então, em minūsculas vēnulas anastomosadas, comumente nos locais de ocorrēncia de piroxenitos. E difícil precisar se é produto de alteração hipōgena ou supergena. A segunda,cons tituindo veios orientados segundo um sistema de fraturas (Fo to no 29) ou em faixas irregulares, cortando as ultramāficas.

Os veios de vermiculita tēm espessura bastante va riāvel, desde alguns centīmetros atē aproximadamente $2 \mathrm{~m}$, sem contar as pequenas digitações que se alongam perpendicular mente ao veio. 0 contato é abrupto. As placas de vermiculi ta se dispõem em todas as direções, atingindo atē $20 \mathrm{~cm}$ de comprimento (Foto no 31). Pelo menos em um local, o dunito e cortado por fraturas anastomosadas, ao longo das quais so luções hidrotermais subiram formando vermiculita de granula ção fina e, ao mesmo tempo, descoloriram a ultramāfica.

Tanto quanto se pode observar em superfície e algu mas dezenas de trincheiras, os veios de vermiculita não man têm a espessura na horizontal e podem adelgaçar na vertical, desaparecendo quase que abruptamente. A granulação da vermi culita é mais grosseira no bordo superior do veio e diminui em direção ao contato inferior. Nas proximidades do contato inferior, tanto no veio quanto na encaixante, a quantidade de opacos, segundo observações de campo, é maior.

Nos contatos dos veios de vermiculita com a enca xante, pode se formar piroxēnio recristalizado grosseiro. Etas variações estão representadas no esquema da Figura nọ 27. Se bem que os veios sejam encontradiços em quase todo o complexo ultramāfico, algumas zonas são preferenciais, com veios potentes, contendo placas de vermiculita mais grossei ras. Estas características parecem indicar uma origem hidro termal para a vermiculita e os opacos associados. 
Fig.27-ESQUEMA DAS ZONAS DE MINERALIZAÇÃO DE VERMICULITA E OPACOS, EM DUNITOS, PERIDOTITOS E PIROXENITOS

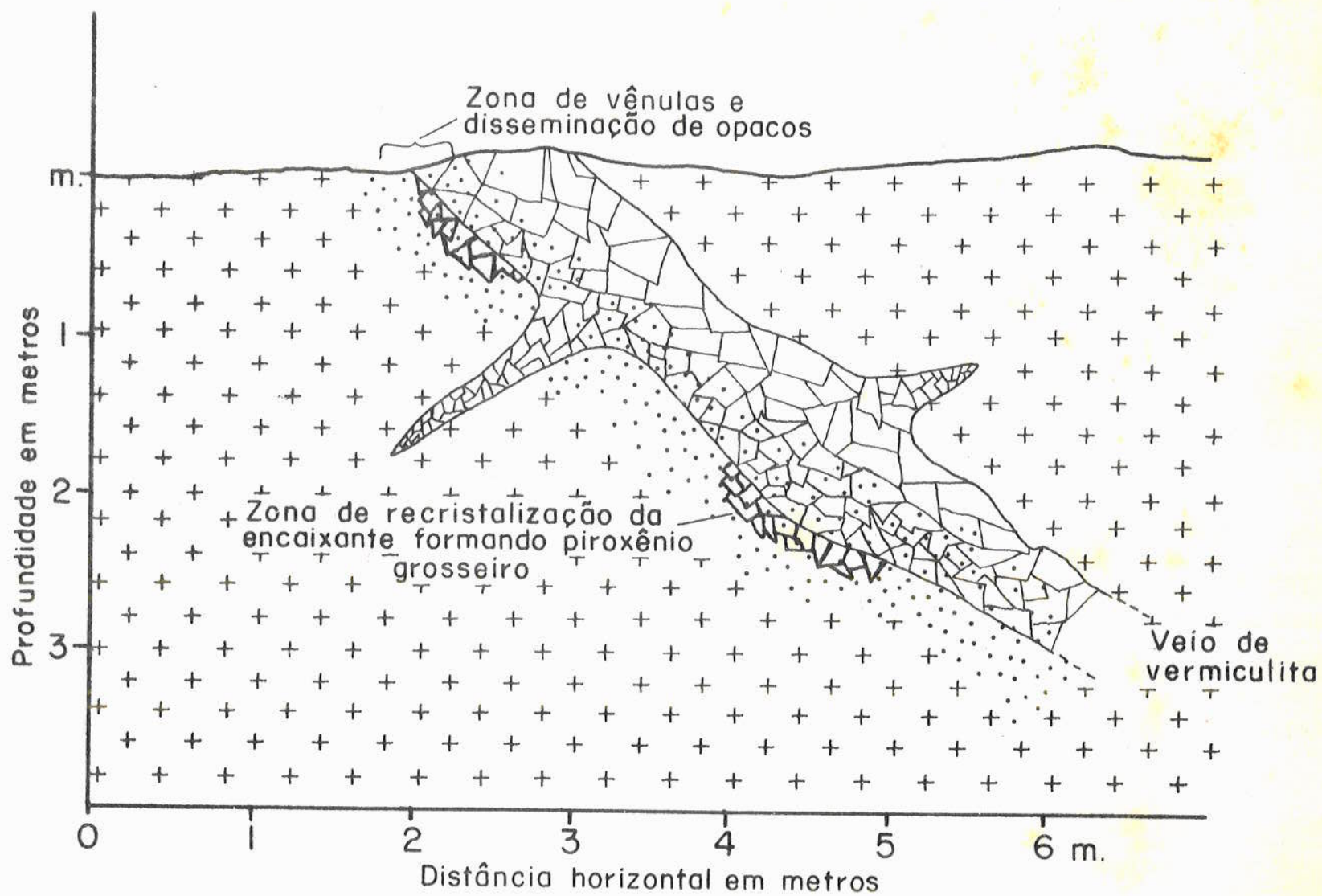

L E G N D A

$\left[\begin{array}{l}++ \\ ++\end{array}\right.$

Y. Veio de vermiculita grosseira às vêzes gradando a vermiculita fina na base.

Digitações de vermiculita fina

. Opacos disseminados ou em vênulas na vermicu$\because$ :- lita ou ultramáfica 


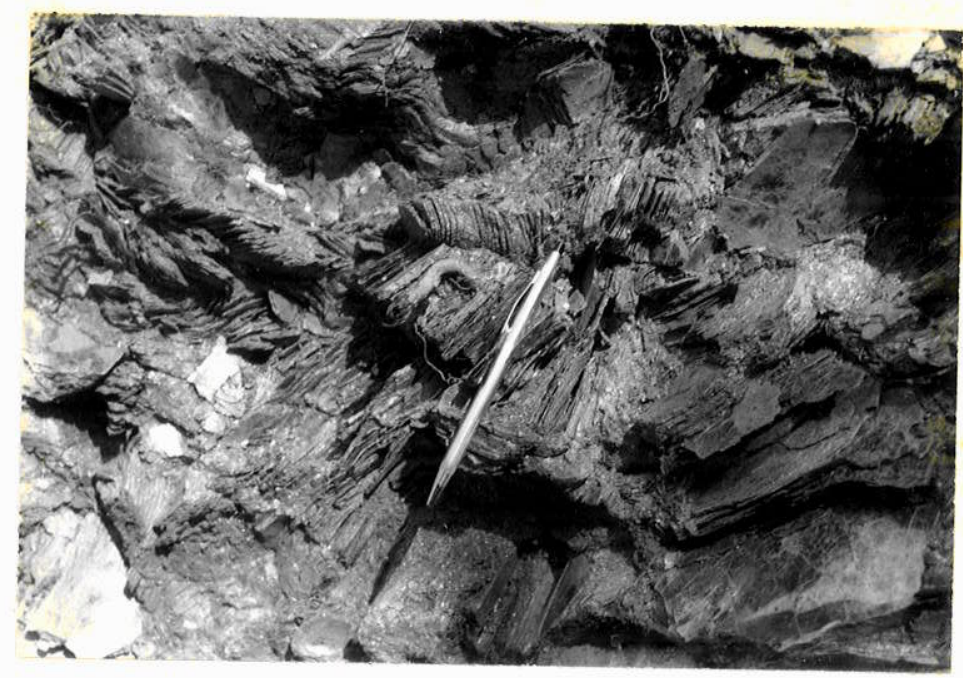

Foto 31 - Placas de vermiculita grossei ra, sem orientação preferencial. Dimensão māxima de 25 $\mathrm{cm}$. Região $\mathrm{S}$ do Tirapressa. 


\section{IX.II - "GARNIERITA"}

Sob este tītulo não serā definido restrita ou am plamente o mineral "garnierita". Apesar da controvērsia so bre os minerais portadores de $\mathrm{Ni}$ incluídos nesta designação, os termos mais comuns utilizados para os componentes niquelí feros das lateritas da Nova Caledōnia são a garnierita, a nepouita e a noumeita.

SPANGENBERG (1938) definiu três principais tipos de silicatos magnesianos hidratados portadores de Ni. Sua sugestão foi seguida por FAUST. (1966), caracterizando os três seguintes tipos:

a. pimelita, mineral do tipo montmorillonita;

b. schuchardita, uma clorita niquelifera; e

c. membros do grupo da serpentina, portadores de $\mathrm{Ni}$.

FAUST (op.cit.) sugere que o termo "garnierita"não tenha conotação de espēcie mineral, mas, seja relacionado a hidrosilicatos magnesianos portadores de $\mathrm{Ni}$. DEER et al. (1962, p. 175) define a garnierita como uma Ni-serpentina que ocorre naturalmente; contudo, BETEKHTIN (p. 544) coloca este mineral como sinōnimo da noumeita.

Deixando de lado a controvérsia na definição do termo, observa-se que no distrito de Santa Fé a "garnierita" ocorre na forma disseminada, constituindo parte do "preenchi mento" de "box work" silicosos locais, ou, formando vēnulas nas ultramāficas alteradas, com espessura māxima de alguns centīmetros. Não ocorre de forma visível no solo ferralîti co marrom ou amarelo. Sua coloração varia de branca a ver de-garrafa, sendo esta ūltima a cor tîpica. Foi vista em dú 
nitos e peridotitos, em topografia inclinada e em zonas pla nas e rasas.

A formação de crostas de calcedōnea protege a topo grafia local, permitindo a atuação dos fenōmenos intempérí cos sem a interferéncia direta da erosão. Estas condições favorecem a formação de garnierita disseminada e em vēnulas logo abaixo da crosta de calcedonea, elevando os teores de $\mathrm{Ni}$ a valores extremamente altos.

Vénulas de garnierita, aparentemente isentas de impurezas, indicaram em difratogramas de pó de raios $x$ a pre sença de quartzo, clorita (montmorillonita), antigorita e lizardita, alēm de garnierita.

As cores da garnierita variam de amostra para amos tra. Seu campo de estabilidade parece se estender desde o saprōlito fino, abaixo do solo ferralítico amarelo, atē o limite inferior de alteração da ultramāfica, em profundidades ao redor de $20 \mathrm{~m}$. Duas vēnulas de garnierita, uma de cor verde, superficial, e outra branca, a $19 \mathrm{~m}$ de profundida de, foram dosadas em seu conteūdo aproximado de Ni, utilizan do-se dimetilglioxima. Ambas apresentaram teores de $N i$ pró ximos, e apesar do contraste de cor, mesma composição minera lögica para os componentes portadores daquele elemento. Nos difratogramas da Figura 28 observa-se que as duas primeiras raias nītidas correspondem às duas principais reflexões das serpentinas. Desde que a hoshita apresenta-se nos dois difratogramas, com uma raia individual, e segundo esta raia, com representação quantitativa semelhante, conclui-se que as reflexões do difratograma 1 são intensas devido à quanti dade de magnesita, o que, aliās, é confirmado pela cor da amostra. 


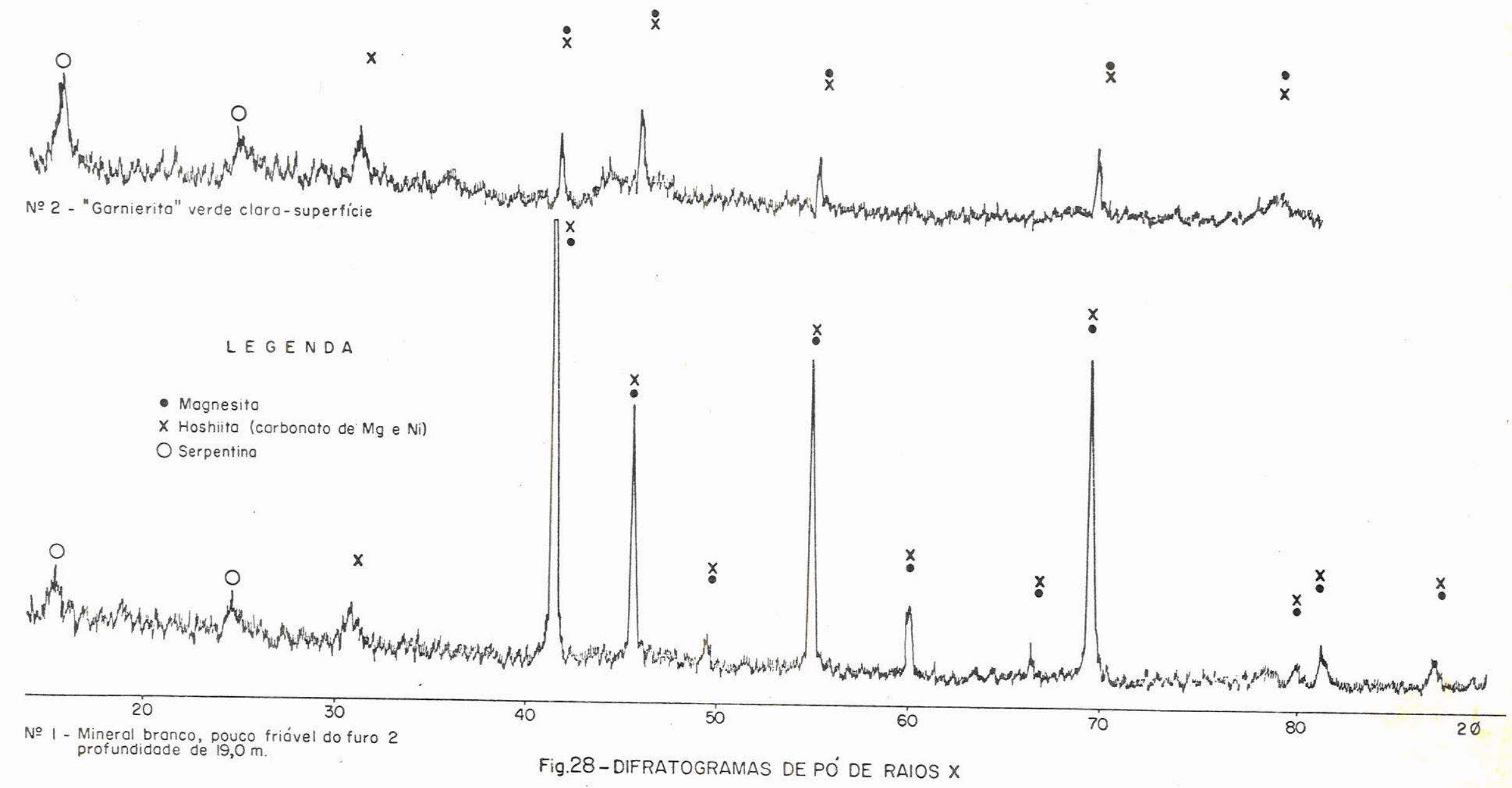


IX.III - CALCEDÔNEA

São encontrados ainda no distrito de Santa Fé al guns raros vestígios de crostas locais de calcedonea capean do parte de morros isolados. Em espessura bastante vari vel, chegam a atingir localmente $4 \mathrm{~m}$.

0 estudo de várias lâminas delgadas revelou serem elas constituídas de quartzo microcristalino, depositado em camadas sub-horizontais, localmente curvas, seguindo o subs trato rochoso alterado ou os espaços vazios disponiveis pa ra a deposição. A cor varia de branca a rosa, esta ūltima aparentemente com hidróxidos de ferro finamente distribuídos.

Adotamos a definição de calcedōnea dada por MIDGLEY (1951), explicada por DEER (1962), p. 209, V. 4, co mo sendo quartzo microcristalino com um grande nümero de mi croporos. Segundo estes autores, evidencias de raios $x$ in dicam que a quantidade de opala, se houver, deve ser consi deravelmente menor que $10 \%$.

Complementação da bibliografia sobre calcedōnea pode ser obtida em SOSMAN (1927), que faz considerações so bre as cores, alēm de seu aspecto bandadoou maciço. Com ba se em investigações roentgenogrāficas, KLOCKMAN, p. 436,não faz distinção entre a calcedōnea e o quartzo.

Em estudo microscópico de amostras de calcedōnea do distrito, ficou evidente a presença local de quartzo de granulação mais grosseira, mas quantitativamente não repre sentativo nas amostras estudadas.

A sîlica, em seu processo de deposição, ē condi cionada por elementos planares ou semi-retilíneos da rocha 
ou tectōnica superimposta. Todavia, o processo de deposição, uma vez iniciado, passa pelas seguintes fases:

a - preenchimento de um sistema esparso de peque nas fraturas de atitude predominante horizontal (Foto 32) e, localmente, microfraturas paralelas de maior densidade (Fo to 33). Neste processo inicial de silicificação a sîlica permanece com a cor branca;

b - adensamento e compartimentação, com a formação de um "box work" silicoso de coloração branca. Lixiviação quase completa da rocha alterada envolvida no "box work" (Fo to 34 );

c - cimentação dos espaços vazios, formando zonas descontínuas preenchidas por sîlica de coloração branca ou rosada;

d - cimentação completa e formação de camadas hor $\underline{i}$ zontais, constituindo uma crosta maciça de sîlica de cor brān ca ou rosada (Foto 35). No processo de transporte a sîlica permanece em solução coloidal e é arrastada com o Mg.

Uma vez depositada, ela não é mais solubilizada, sendo removida apenas com o abaixamento da superfície de ero são, por degradação física. Estas fases não são continuas nem consecutivas e, via de regra, são interrompidas antes da formação da crosta maciça.

A silicificação ocorre em nỉveis ou zonas especîf cas, entre as quais podemos enumerar:

10 - capeando a superfície de alguns morros, hoje constituindo crostas residuais em estado de desagregação fí sica;

20 - constituindo platōs de pequena altitude, for mando, no momento, soleiras que impedem a erosão. Estes 


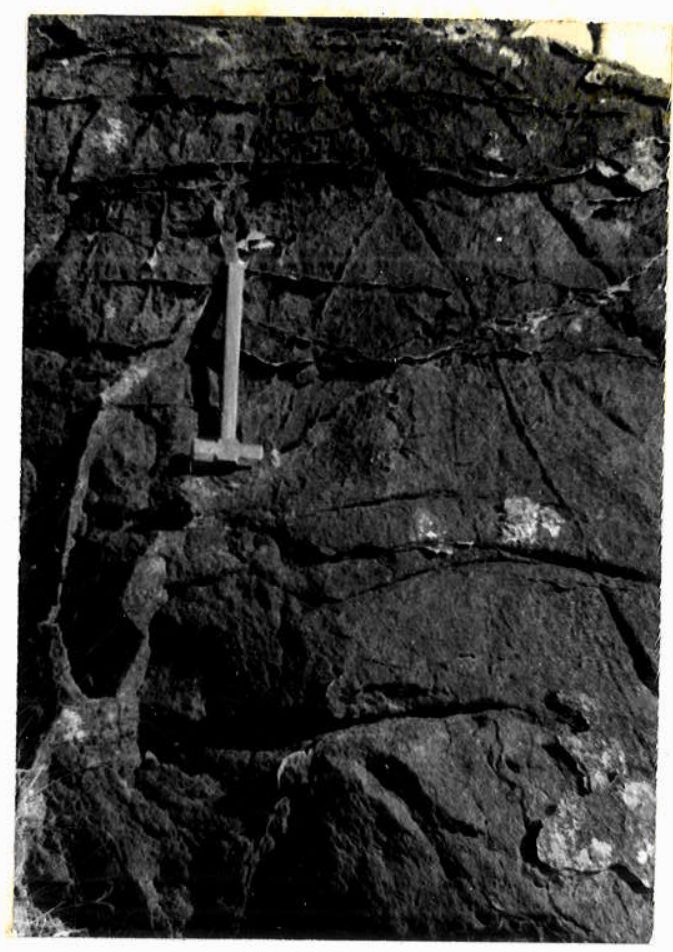

$-103-$

Foto 32 - Vênulas de calcedōnea em fraturas predominantemente horizontais. Encosta dunitica do morro do Tirapressa.

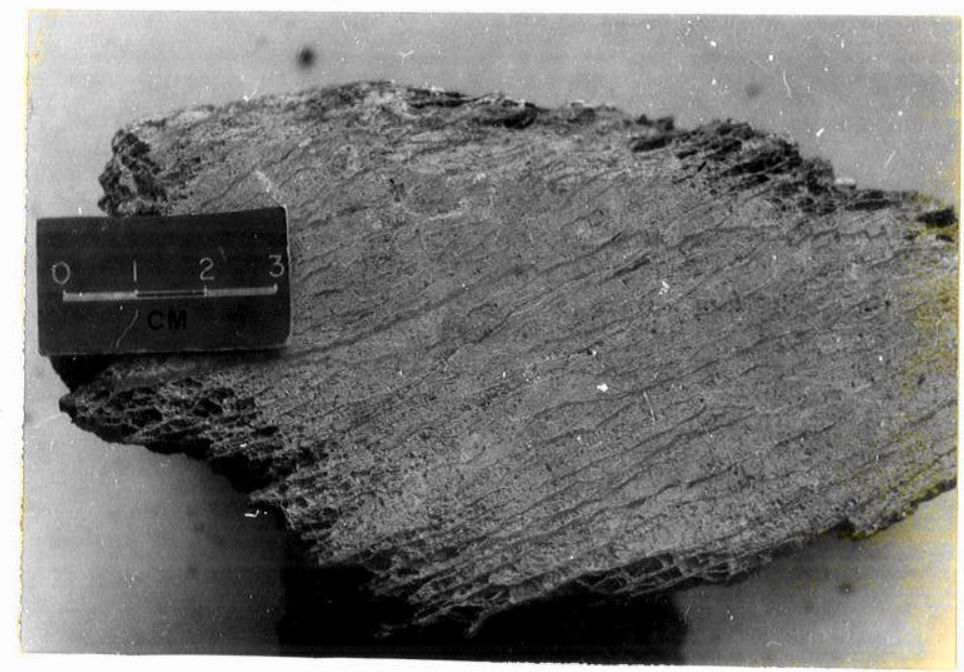

Foto 33 - Microfraturamento paralelo preenchido por sílica de cor branca. 


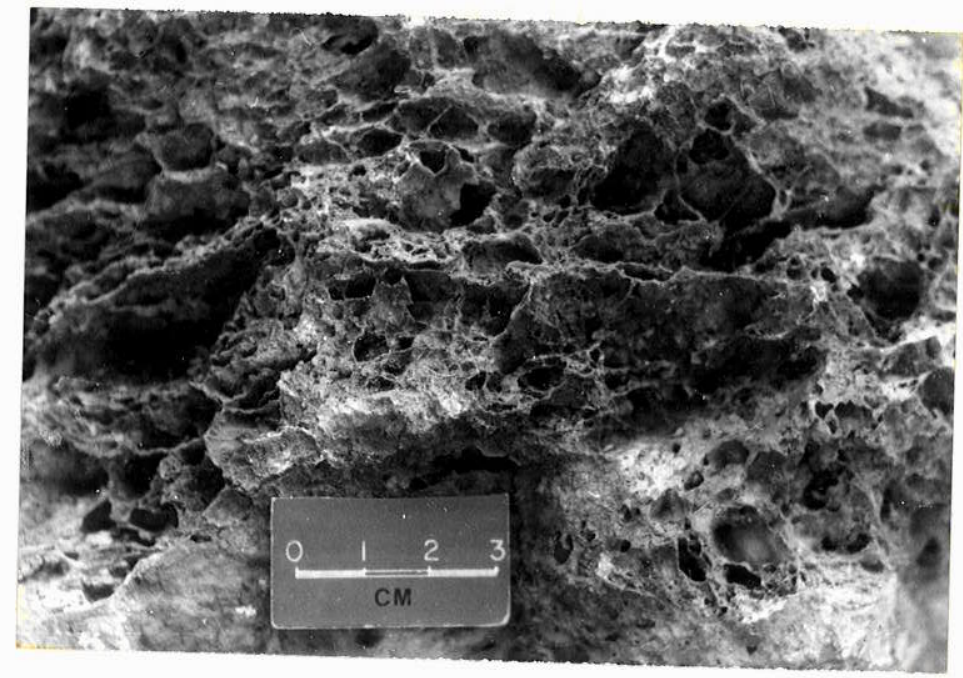
Foto 34 - "Box Work" silicoso, de coloração branca. Morro do

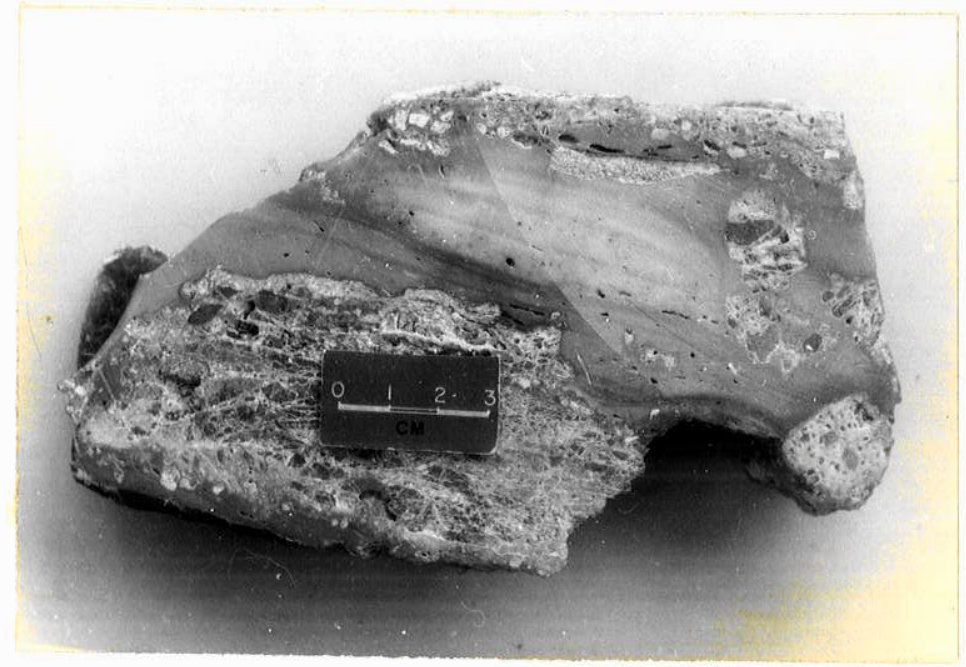

Foto 35 - Crosta maciça de calcedōnea, de coloração branca ou rosada. Restos de ultramäfica alterada engloba-
dos. SW do Morro do Tirapressa. 
platōs não foram localizados nas zonas baixas. A completa destruição dos platōs pode acarretar a formação de um horizonte clāstico de blocos de calcedōnea na forma de elūvio, próximo e logo abaixo do local original de formação da crosta. Como exemplo de plató de certa altitude, observou-se a soleira de calcedōnea que atravessa ao longo dos poços

N 48 W 7, N 49 W 7 e N 50 W 7 na ärea III, com um comprimen to total de aproximadamente $300 \mathrm{~m}$;

$$
30 \text { - em carāter mais restrito e local, podem-se }
$$

formar horizontes de calcedōnea celular a alguns metros de profundidade, correspondendo a interfácies de diferentes zo nas, comumente entre o solo ferralitico amarelo e o saprōi to fino. No poço $A D-1$, um horizonte de calcedōnea celular estende-se desde os $3,0 \mathrm{~m}$ de profundidade atē os 5,2 m. Mu dança de $\mathrm{pH}$ deve ser o principal fator provocador da precipi tação da sîlica neste horizonte. Alguns nîveis de silicifi cação localizam-se tambēm dentro da ultramāfica alterada, possivelmente condicionados pela posição do lençol freātico; e

40 - constituindo vēnulas distribuídas na ultramā fica alterada, que se adensam com o avanço do fronte de eró são, segundo foi descrito no item b.

Quanto à distribuição na vertical, as Figuras 9 e 10 indicam que a sîlica é comumente depositada desde o solo ferralitico amarelo atē o limite inferior da ultramāfica al terada. Vênulas de calcedōnea na rocha serpentinizada mais profunda são raras. Pode-se inferir que a silicificação, na forma como foi descrita, não deve ter relação com os proces sos ascendentes responsāveis pela serpentinização. Consequen temente, deve se relacionar aos processos intempéricos des cendentes.

Vale lembrar que, ao longo do perfil, parte da sí 
lica seria consumida para a formação de silicatos hidratados de $\mathrm{Ni}$ e $\mathrm{Mg}$, e, que a alteração e concentração de Ni processa-se em um quadro dināmico de evolução gradual e contīnua. Es tas condições emprestam características prōprias ao perfil esquemático da Figura 10 que se localiza em topo ou encosta de morros.

\section{IX.IV - MINERAIS OPACOS}

Os minerais opacos constituem uma delgada e descon tinūa cobertura na superfīcie topogrāfica baixa do distrito, mas, tambēm, ocorrem em zonas preferenciais (Figura 27) apa rentemente relacionadas geneticamente à vermiculita. 0pacos dispersos nas rochas ultramāficas e opacos concentrados lo calmente nos contatos dos veios de vermiculita com as enca $\underline{i}$ xantes são, apōs alteração e liberação, a fonte de suprimen to para a concentração superficial.

Amostras representando cristais individuais de gra nulação fina e agregados de cristais grosseiros foram sepa radas com um ímã manual do tipo alnico, distinguindo-se três grupos:

10) agregados de minerais de magnetismo forte; 20) agregados de minerais de magnetismo fraco; e 3o) agregados de minerais não magnéticos.

\section{0 - Agregados de minerais de magnetismo forte}

os minerais desse primeiro grupo são os mais repre sentativos no distrito e ocorrem constituindo um eluvião de concentração maior em āreas onde aparentemente os veios de 


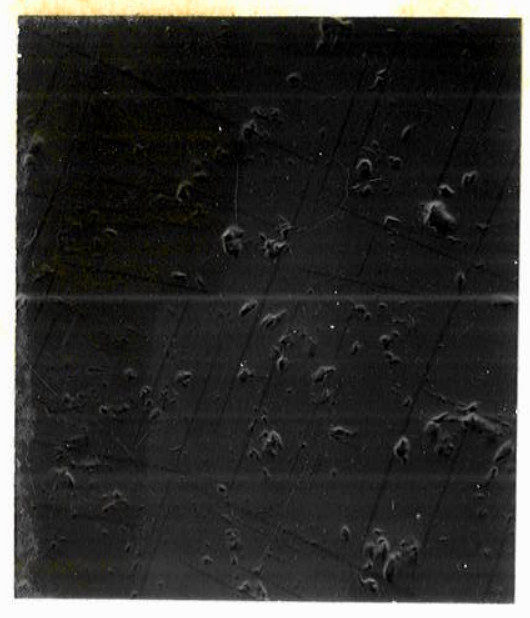

\section{$-107-$}

$$
\text { Seção E-1 - Comp. } 300 \text { X }
$$

Seção E-2 - Comp.1000X
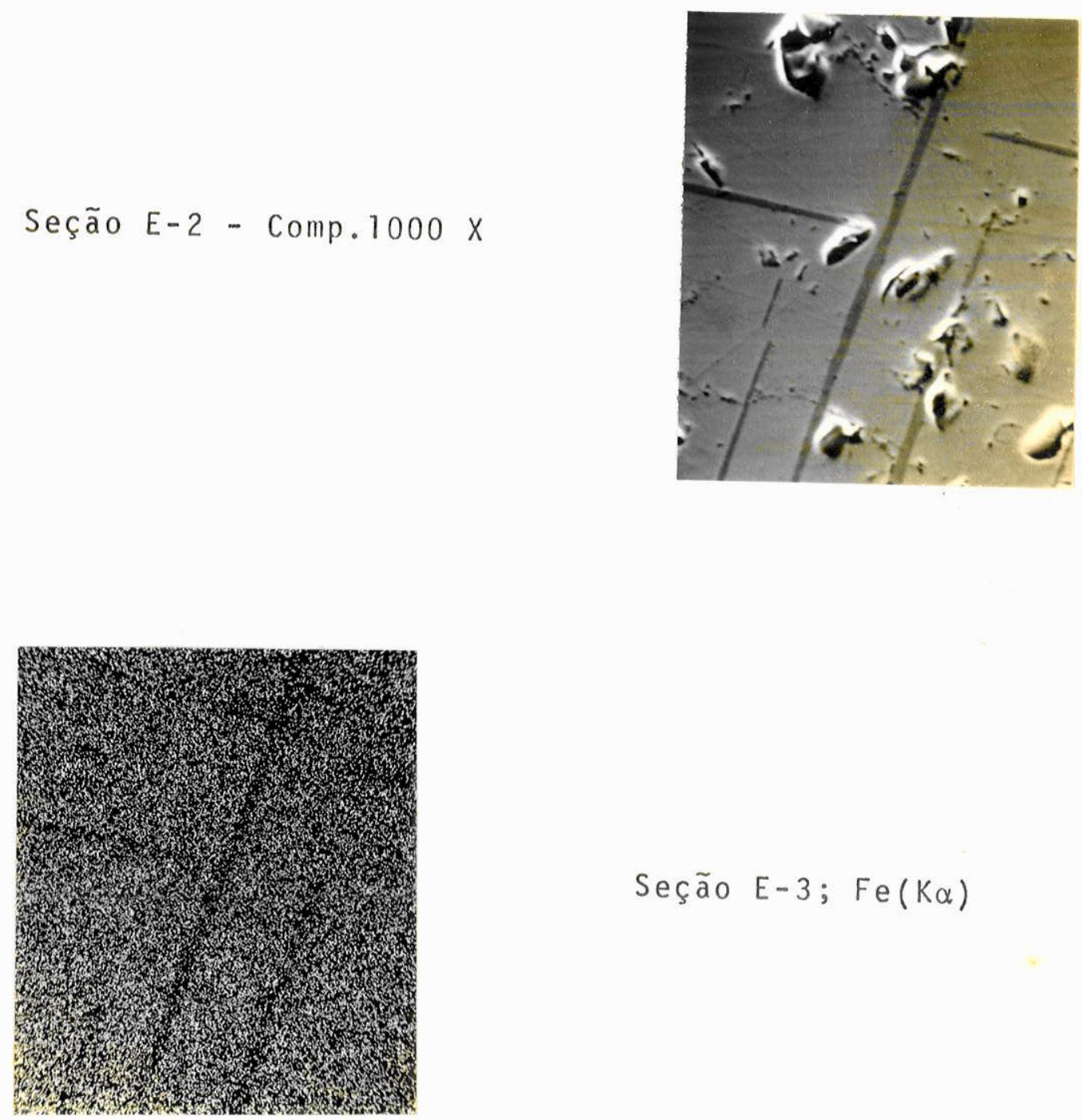

$$
\text { Seção } E-3 ; \mathrm{Fe}(K \alpha)
$$




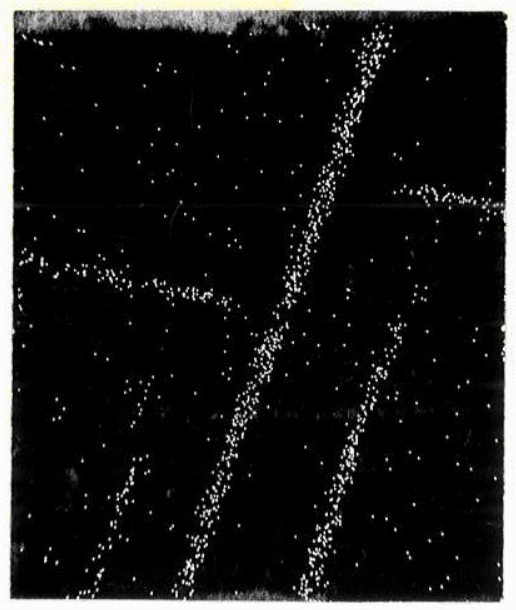

$$
\text { Seção } E-4 ; T i(K \alpha)
$$

Seção $E-5 ; M g(K \alpha)$
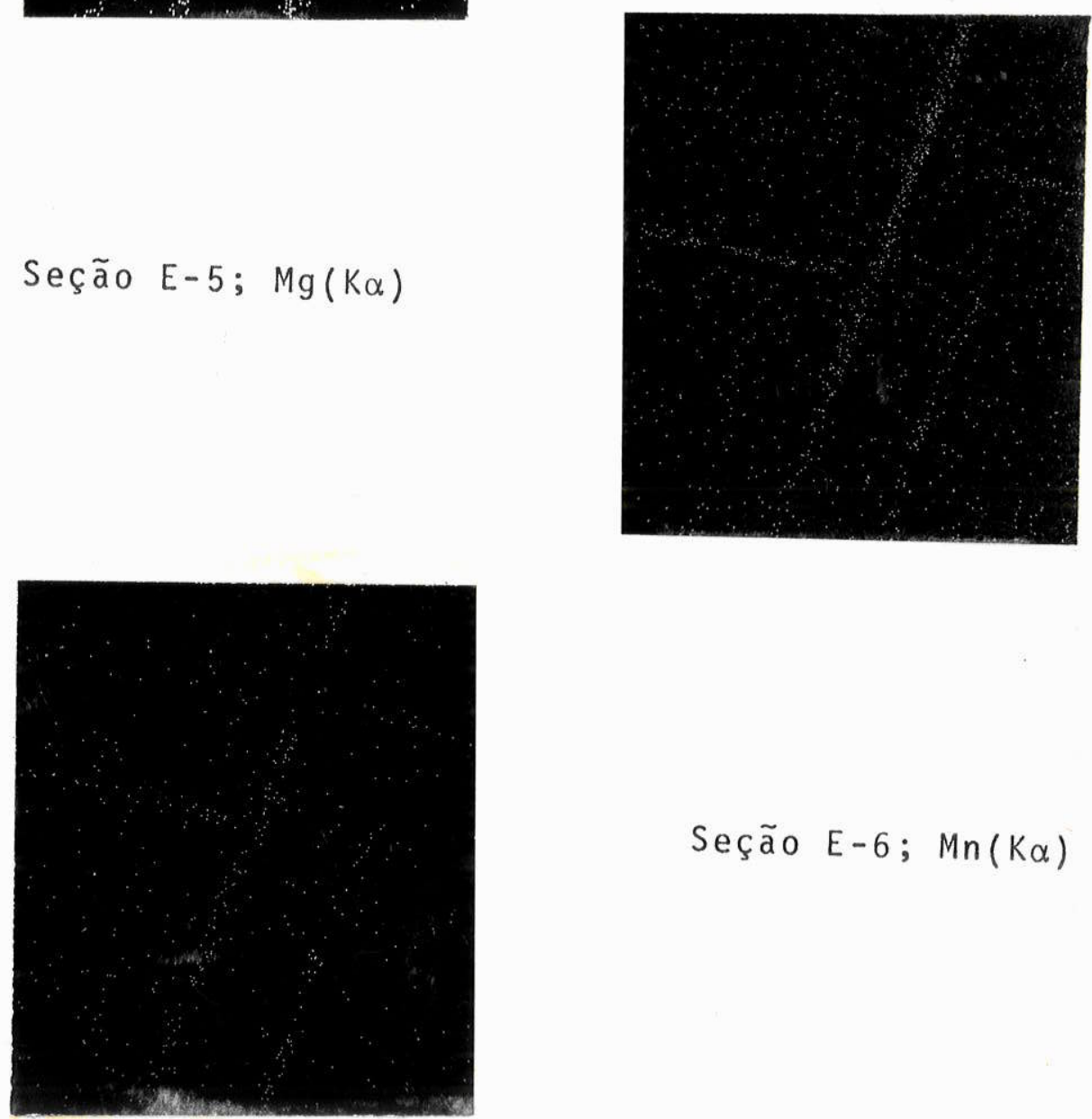

Seção $E-6 ; M n(K \alpha)$

Foto 36 - Seções de E-1 a E-6 - Micrografia eletrōnica microssonda. Magnetita com lamelas de ilmenita.A ilmenita é menos rica em Fe, mas contém bastante $\mathrm{Ti}$ e algum $\mathrm{Mg}$ e $\mathrm{Mn}$. 
vermiculita são mais comuns. Pertencendo a este grupo foram identificados os seguintes minerais: magnetita, maghemita e ilmenita.

Descrição de cada um dos minerais deste grupo:

a) magnetita

$\mathrm{FeFe}_{2} \mathrm{O}_{4}-0 \mathrm{Fe}$ II pode ser substituído por

$\mathrm{Mg}, \mathrm{Mn}, \mathrm{Zn}, \mathrm{Ni}$ e Ti. O Fe III pode ser substituído por:

A1, Ti, $\mathrm{V}$ e $\mathrm{Cr}$.

Pertence ao sistema cūbico.

Características observadas: Este mineral è predo minante no grupo de magnetismo forte. Constitui cristais de dimensões milimētricas atē agregados de $20 \mathrm{~cm}$. 0s cristais individuais chegam a ser decimëtricos. 0 magnetismo é forte, dependendo do grau de martitização.

Cor cinza, com matiz marrom rosada, provavelmente devido à presença de $\mathrm{TiO}_{2}$. A refletividade é baixa, com cli vagem não distinta. Isōtropo, com predomināncia aparenté de octaedros. 0xidação ao longo dos planos (111) de octae dro, formando um reticulado triangular de lamelas de hematí ta (martitização). A Foto 37 ilustra magnetita em fase de martitização.

Alēm da martitização normal, lamelas de hematita podem se formar na borda do contato da ilmenita com a magne tita.

De acordo com KABESH et al., 1958, magnetita pode ser de origem hidrotermal ou pneumatolitica. Na serpentini zação da olivina o Fe é remobilizado e forma magnetita.

Segundo vārios autores, as situações em que a mag 


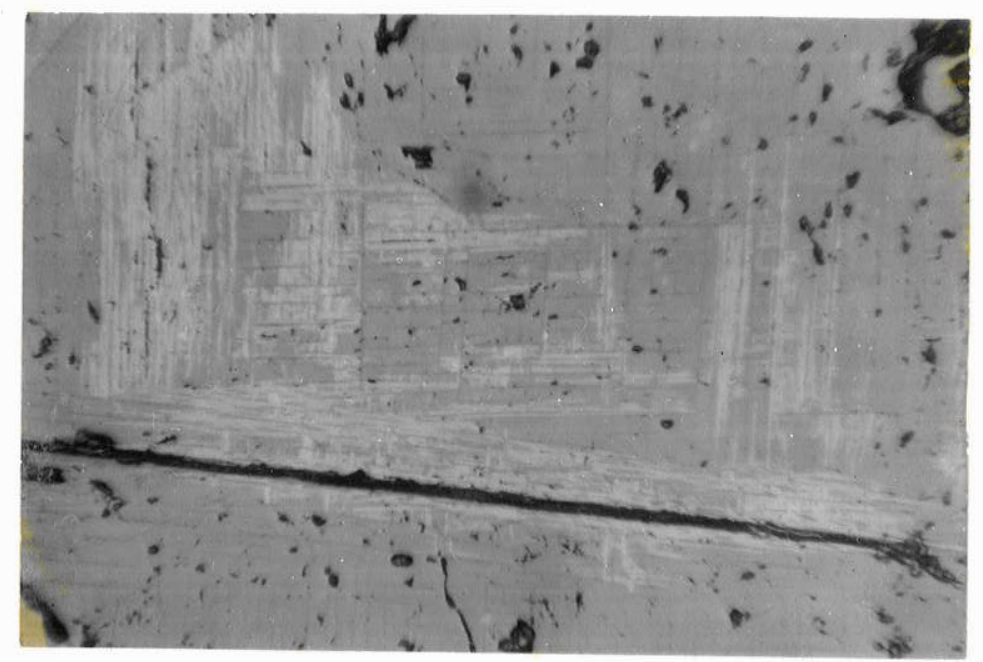

Foto 37 - Martitização (cinza-claro) da magnetita (cinza më dio) ao longo dos planos (111). Notar lamelas de ilmenita (cinza mais escuro) delgadas, seguindo o mesmo sistema. Escala: 440 X; Seção APB 102. 
netita se forma em condições de baixa temperatura são quanti tativamente tão pouco representativas que, invariavelmente, a presença de magnetita indica temperatura de formação relati vamente alta.

b) Maghemita

$\gamma-\mathrm{Fe}_{2} \mathrm{O}_{3}$

cūbico.

Forma instāvel de $\mathrm{Fe}_{2} \mathrm{O}_{3}$, pertencente ao sistema

Caracterīsticas observadas: Cor cinza, isōtropa, bastante magnētica. Refletividade maior do que a da magne tita e menor do que a da hematita.

A maghemita deve ter se formado a partir da magne tita, formando uma superfície esponjosa, salpicada de minūs culos furos. Esta substituição é irregular, sem qualquer orientação cristalogrā́fica. Segundo RAMDOHR (1969), impure zas de $V$ ou Ti parecem favorecer a formação de maghemita e a tornam mais estāvel. BASTA (1969, a, b) concluiu que deve haver uma série transicional entre a magnetita e a maghemita, sendo que neste processo a dimensão da cela unitāria diminui de aproximadamente $0,06 \mathrm{~A}$. Mesmo com a transformação da mag netita em maghemita, as lamelas de ilmenita, formadas no pri meiro mineral, resistem à oxidação.

c) IImenita

$\mathrm{FeTiO}_{3}$ (contēm comumente $\mathrm{Fe}^{3+}, \mathrm{Mn}^{2+}$ e $\mathrm{Mg}$ )

Pertence ao sistema hexagonal.

Características observadas: Cor cinza clara com ma tizes marrons. Anisotropia forte, com reflexões internas mar rom escuras.

A ilmenita ocorre na forma de lamelas de espessura constante, via de regra ao longo dos planos (111) da magneti 


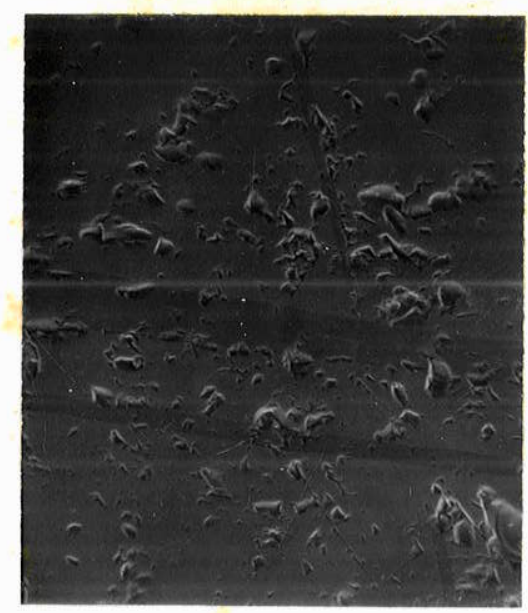

\section{Seção F-1 - Comp. 300 X}

Seção F-2 - Comp. 1000 X
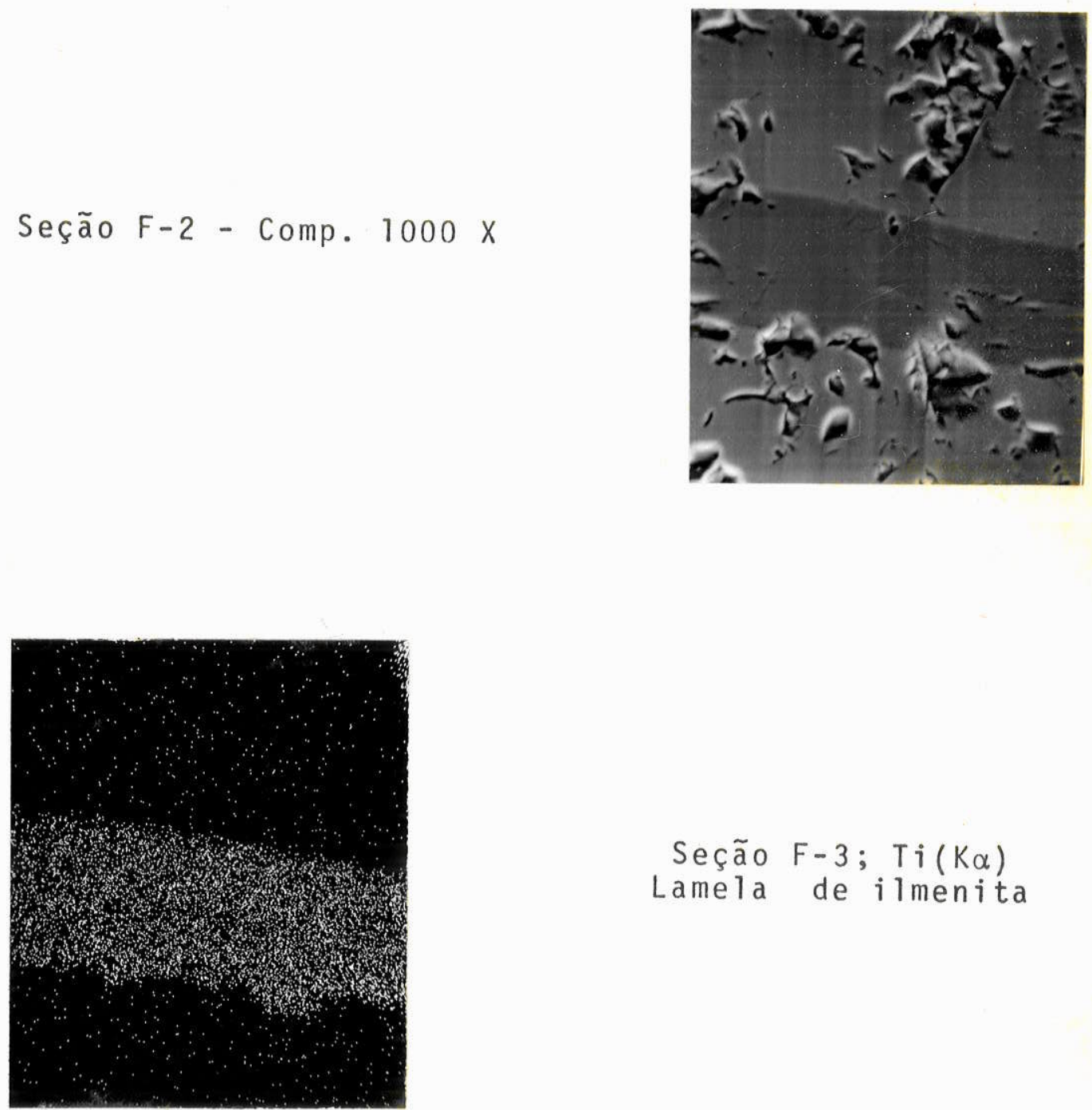

Seção $F-3 ; T i(K \alpha)$

Lamela de ilmenita 


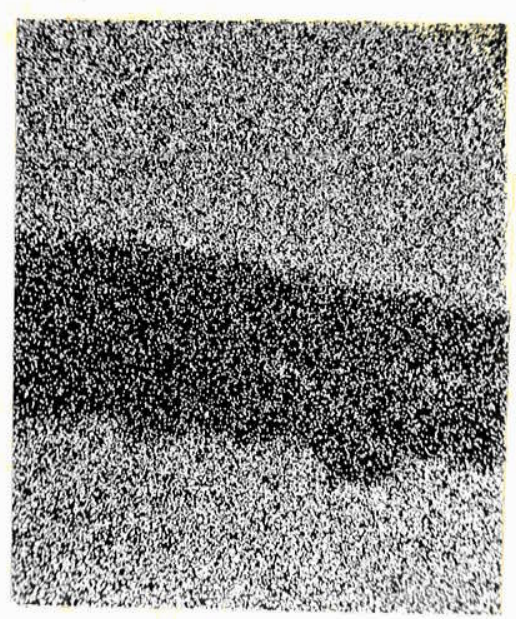

Seção F-4; $\mathrm{Fe}(K \alpha)$

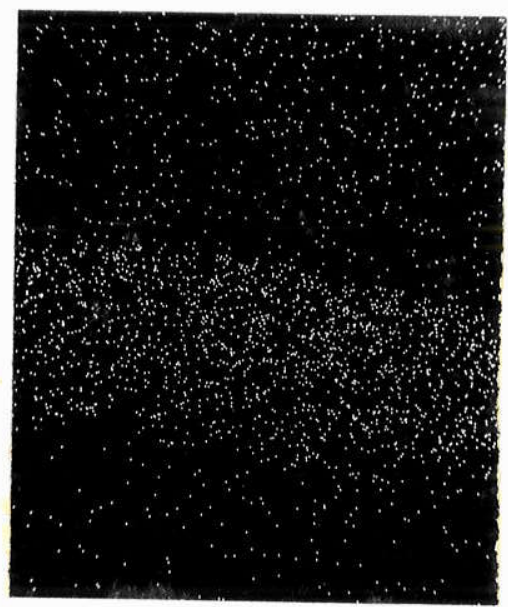

Seção F-5; $M g(K \alpha)$

Foto 38 - Seções F-1 a F-5 - Micrografia eletrōnica e microssonda. Maghemita com lamelas de ilmenita ao longo dos planos (111) da magnetita transformada. Superficie picotada e a ilmenita resistindo à oxi dação. 
ta, formando um reticulado. Lamelas em magnetita,orientadas segundo apenas um plano, podem ser vistas na Foto 39. Pode formar, além de lamelas, zonas ou faixas irregulares dentro dos cristais de magnetita, herdada também na maghemita. cli vagem não é visível. E mais resistente à oxidação do que à magnetita.

Lamelas de ilmenita ou hematita no plano (111) da magnetita têm sido interpretadas como evidēncia indiscutĩvel de solução sōlida por vārios autores, entre eles, EDWARDS (1965), RAMDOHR (1969) e UYTEMBOGAARDT (1951).

Em sua forma pura è não magnética (RAMDOHR, 1969) na temperatura ambiente. Segundo o mesmo autor, a ilmenita é formada apenas muito raramente em depōsitos hidrotermais ascendentes. E um importante "termōmetro geolōgico" e for ma-se exclusivamente a altas temperaturas, certamente acima de $500^{\circ} \mathrm{C}$.

Uma amostra de ilmenita e magnetita foi submetida à anālise quỉmica por absorção atômica para dosagem de $\mathrm{Zn}$, $\mathrm{Cu}$ e Ni e por via úmida para os demais componentes obtendo-se os resultados contidos na Tabela 5 .

Quinze amostras de agregados de minerais de magen tismo forte foram submetidas à anālise quỉmica por via ūmida e absorção atômica para $Z n, C u$ e Ni, obtendo-se os resulta dos constantes da Tabela 6 .

\section{0 - Agregados de minerais de magnetismo fraco}

Este grupo de minerais foi coletado em bordas de trincheiras e poços, prōximo a zonas com veios de vermiculi ta. Corresponde, no mapa geológico, à zona NE da ārea VI. os minerais podem ocorrer como rolados na superficie, mas, via de regra, nas proximidades das rochas fontes, que são zo nas de vermiculita e, tambēm, a prōpria ultrabāsica com miné 


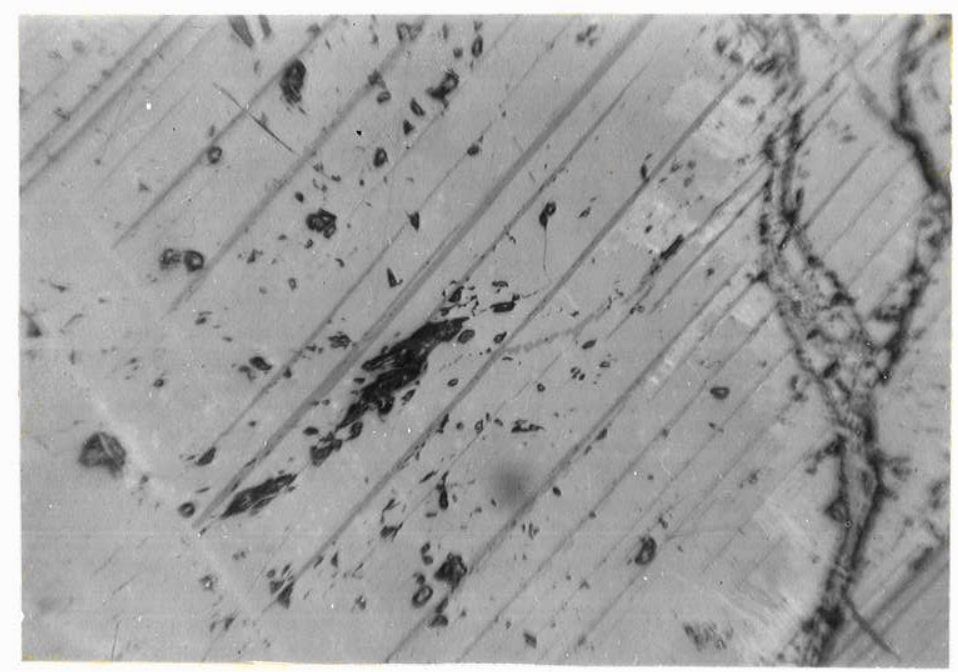

Foto 39 - Lamelas de ilmenita em um dos planos (111) da magnetita. Notar martitização da magnetita ao longo de uma zona de fratura. Ilmenita cinza escura;magnetita çinza mais clara e hematita formada por mar titização, cor cinza bem clara. Aumento $128 \mathrm{x}$. 
TABELA 5

ANALISE QUIMICA DE AGREGADO DE ILMENITA E MAGNETITA AMOSTRA SF-502

$\%$

$\begin{array}{lr}\mathrm{SiO}_{2} & 2,37 \\ \mathrm{TiO}_{2} & 2,79 \\ \mathrm{Al}_{2} \mathrm{O}_{3} & 0,45 \\ \mathrm{Fe}_{2} \mathrm{O}_{3} & 74,05 \\ \mathrm{FeO}^{2} & 17,80 \\ \mathrm{MnO} & 0,40 \\ \mathrm{MgO} & 1,87 \\ \mathrm{CaO} & 0,03 \\ & \\ \mathrm{Cr}{ }^{3+} & \mathrm{ppm} \\ \mathrm{Zn} & 247 \\ \mathrm{Cu} & 250 \\ \mathrm{Ni} & 340\end{array}$


TABELA 6 - ANÁLISE QUIMICA DE AGREgAdOS DE MINERAIS DE MAGNETISMO FORTE

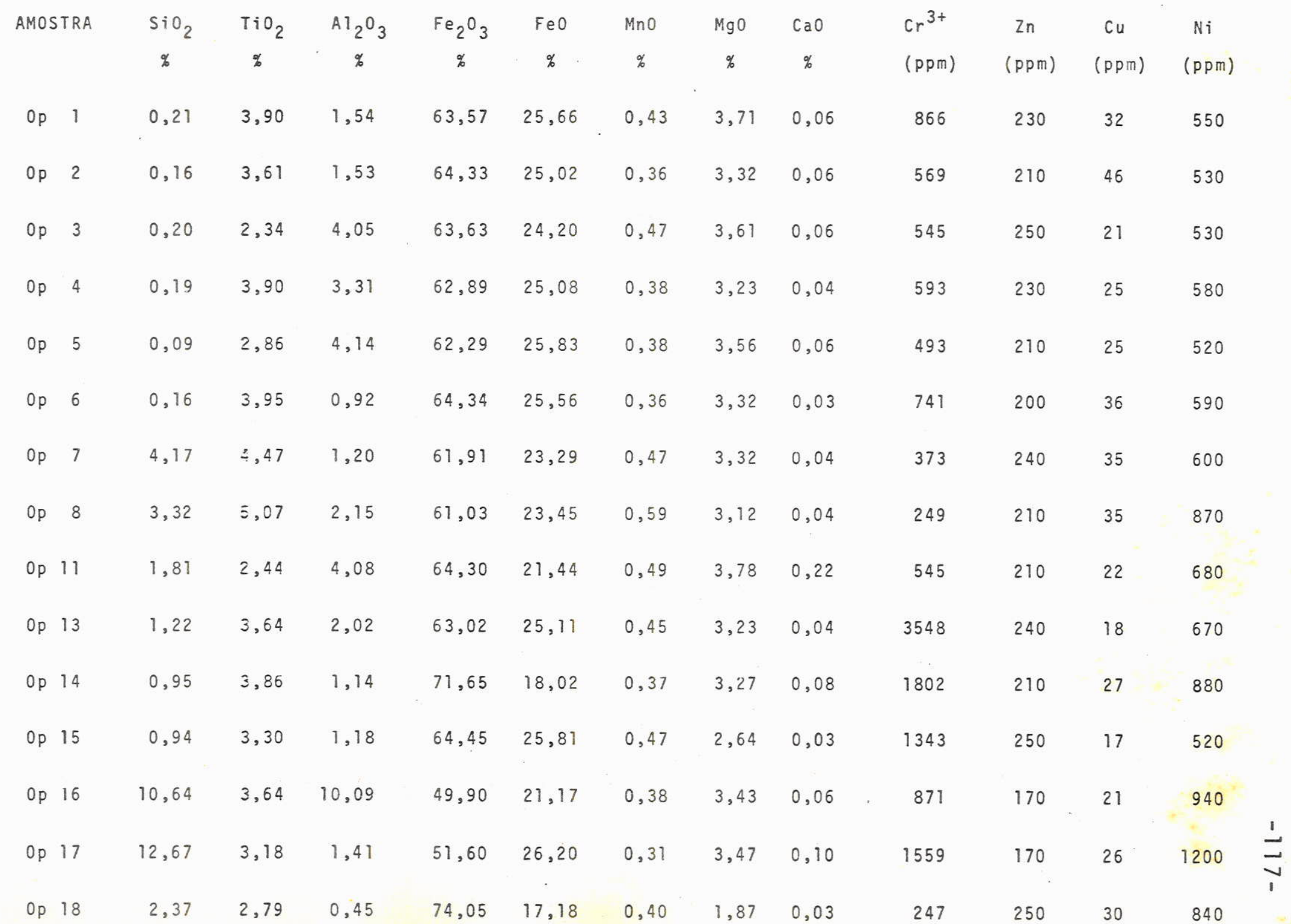


rais disseminados.

A dimensão dos cristais ou agregados è menor do que a do primeiro grupo, isto é, entre $1 \mathrm{~mm}$ e $3 \mathrm{~cm}$.

Pertencendo a este grupo foram identificados os se guintes minerais: magnetita titanífera, hematita, ilmenita, rutilo e galena.

Descrição de cada um dos minerais:

a) Magnetita titanifera

$\mathrm{Fe}_{1+}^{2+} \mathrm{Fe}_{2-2 \times}^{3+} \mathrm{Ti}^{4+} \mathrm{x}^{0} 4$

Sistema cübico.

Caracteristicas observadas: Cor clara, com matiz mar rom; alguns cristais adquirem cor mais amarronzada, dependen do da porcentagem de Ti. Isōtropo, com hābito predominante em octaedros e dodecaedros. Nenhum outro mineral associa-se à magnetita titanífera.

Segundo UYTENBOGAARDT (Nova edição p. 169), magneti ta titanífera pode ser formada pelo resfriamento räpido de uma solução em alta temperatura, composta de magnetita com i! menita ou ulvoespinēlio.

Segundo HEIER (1956, p. 510), hā uma tendência ge ral para magnetitas de alta temperatura conterem altos teores de Ti, mas, adverte, a composição química das soluções minera lizantes influenciam mais diretamente, a porcentagem de $T \bar{i}$ contida na magnetita.

SEMENOV (1974) observa que titano-magnetita em ro chas ultramáficas alcalinas pode ser de origem pneumatoliticá, baseando-se na descrição do distrito de Kovdor (Rūssia), carac terizado por TERNOVOY et al. (1969). 


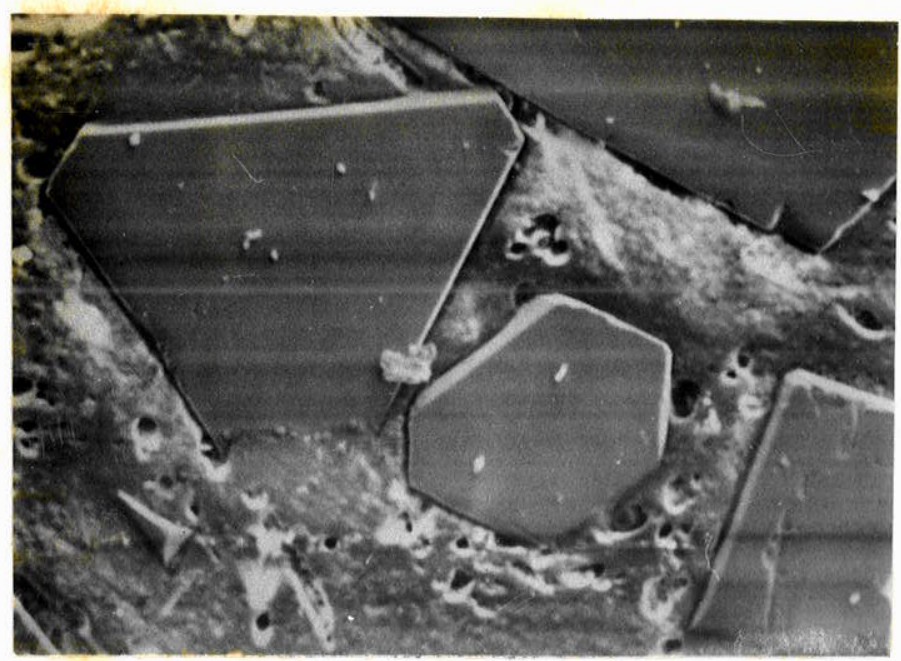

\section{Seção G-1 - Comp.140X}

Seção G-2 - Comp. 300 X
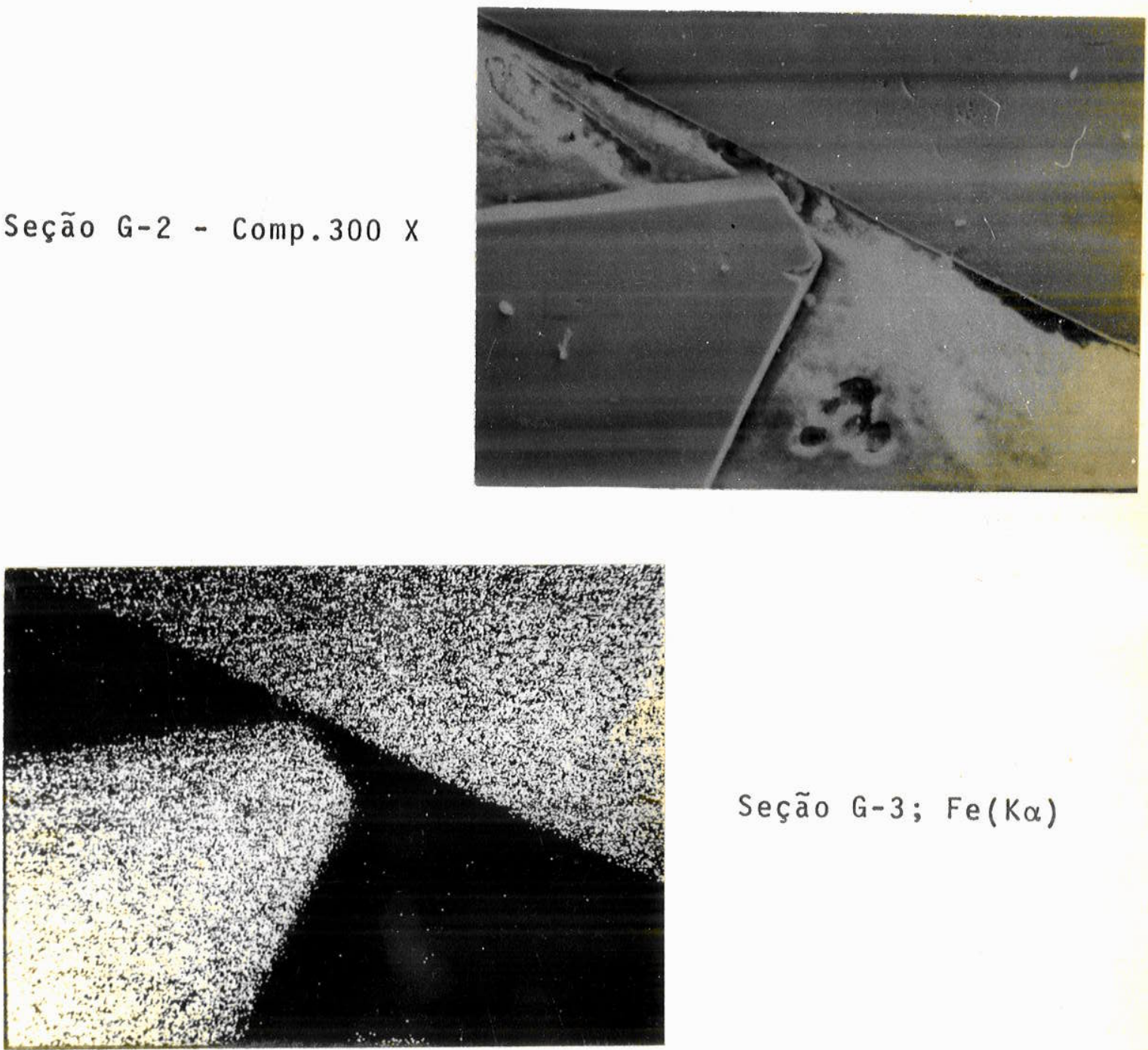

Seção G-3; $\mathrm{Fe}(K \alpha)$ 


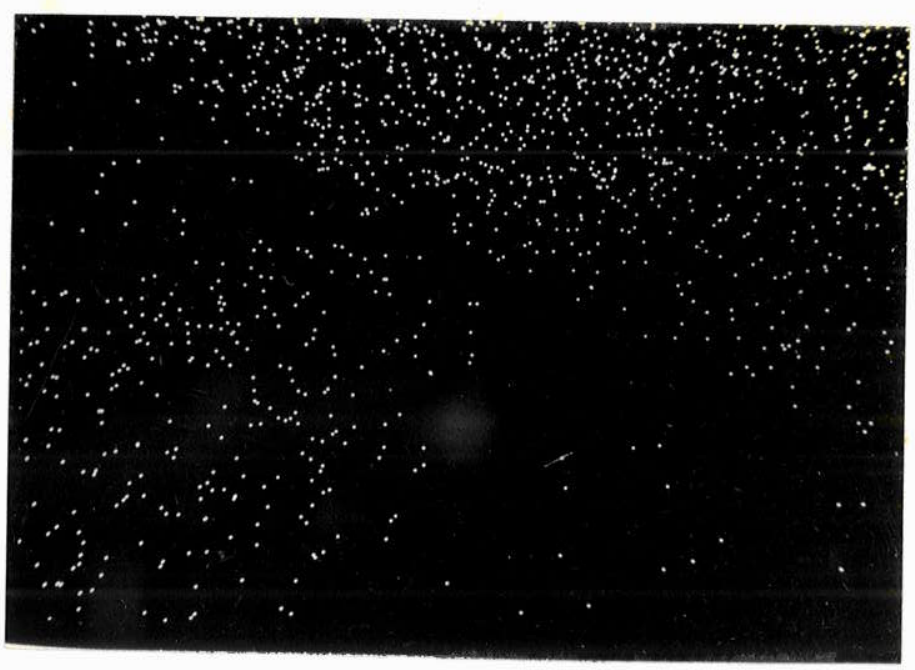

Seção G-4; Ti $(K \alpha)$

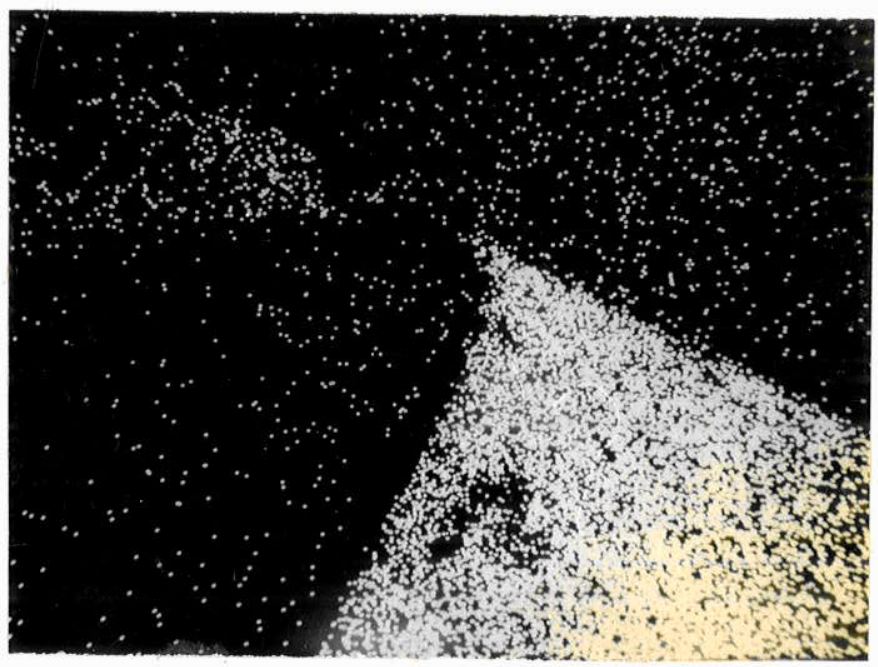

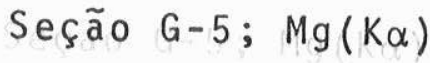

Foto 40 - Seções G-1 a G-5 - Micrografia eletrōnica e micros sonda. Magnetita titanifera; alguns cristais tém mäis Ti que outros. Notar que os cristais são idio 
b) Hematita

$\mathrm{Fe}_{2} \mathrm{O}_{3}$ (pode conter algum $\mathrm{FeTiO}_{3}$ ou $\mathrm{MgTiO}_{3}$ ).

Sistema hexagonal.

Características observadas: Cor cinza clara, refle tividade alta, birrefletāncia fraca, anisōtropa, com refle xões internas marrons.

Do estudo de vārias seções polidas de magnetita,ob serva-se que a martitização efetua-se em trēs fases distin tas, iniciando-se, na primeira fase, com a alteração da mag netita ao longo dos planos de octaedro e constituindo uma rede triangular. Bordas de grãos são martitizados irregular mente. Numa segunda fase, a hematita pseudomōrfica, é ré cristalizada, formando uma textura sacarōide fina e equi granular. Restam, ainda assim, alguns remanescentes de ma $\underline{g}$ netita, pequenas "ilhas" de refletividade menor, isōtropos. A terceira fase processa-se ao longo de fraturas e vênulas, com fatores posteriores à martitização anterior que recrista lizam a hematita novamente, tornando-a mais grosseira e, ain da, de textura sacaróide. Não se nota nenhuma orientação óptica preferencial na hematita formada nas trēs fases des critas.

0 processo de martitização ē operante tambēm ao longo do contato das lamelas de ilmenita com a magnetita. For ma-se, então, um invölucro de hematita em torno da ilmenita. Raramente a ilmenita é substituĩda pela hematita. Com a mar titização praticamente desaparece o magnetismo da amostra.

A martitização pode ser considerada como um prosse guimento do processo de serpentinização, provocada talvez pé 10 decréscimo de temperatura. Segundo RAMDOHR (1969), marti tização provocada por alta temperatura parece favorecer uma direção predominante para as lamelas de hematita. Mas, via 
de regra, a martitização ē um processo secundārio de altera ção, desenvolvendo-se ao longo dos planos (111) de octaedro da magnetita.

E interessante notar que a hematita deve ter se for mado, apenas às expensas da magnetita. Não è geneticamente primāria (1a. geração).

c) IImenita

Idem à ilmenita do grupo I, excluindo-se seu rela cionamento com a maghemita.

d) Rutilo

$\mathrm{TiO}_{2}$ (pode conter algum $\mathrm{Fe}, \mathrm{Nb}, \mathrm{Ta}, \mathrm{V}, \mathrm{Sn}$ e $\mathrm{Cr}$ em solução sōlida).

\section{Sistema tetragonal}

Caracteristicas observadas: Cor cinza, com matiz azulado. Birrefletāncia visível, com reflexões internas in tensas de cores amareladas a marrom avermelhadas. Anisótropo. Cristais com clivagem visível e geminação, embora não muito comum.

Quanto à origem deve ter se formado pela alteração da ilmenita. Raramente estā presente em veios hidrotermais, mas se forma frequentemente nas paredes, a partir da ilmenita.

Tende a ocorrer em assemblēias de alta pressão e alta temperatura. E um mineral comum de alteração de mine rais titaniferos, principalmente ilmenita, magnetita titan $\bar{i}$ fera e perowskita. Ilmenita pode se transformar em rutilo em condições supérgenas, segundo ZIV (1956). Ver tambēm YAROSH (1955) (metamorfismo de rochas e pegmatitos com ilme nita, dando rutilo). 
e) Galena

PbS - pode conter algum Te ou Se substituindo o $\mathrm{S}$ e $\mathrm{Ag}$ em solução sölida.

Sistema cūbico.

Características observadas: Cor clara, refletivida de alta, isótropa: Clivagem cūbica perfeita, com cavidades triangulares tīpicas. E substituỉda por magnetita, que mantēm as cavidades triangulares.

Galena pode se originar em condições de alta, mé dia e baixa temperatura.

Na paragēnese de depōsitos minerais a galena ē um mineral formado posteriormente. Por este motivo, minerais mais antigos são encontrados como inclusões. Galena pode ocorrer em veios pneumatolíticos e em substituições de conta to metassomātico. Mas, seu modo mais comum de ocorrēncia $\bar{e}$ a associação em soluções hidrotermais de vārios tipos.

Uma amostra de agregado de minerais de magnetismo fraco foi analisada por via ümida e absorção atōmica ( $Z n$, Cu e $\mathrm{Ni}$ ), obtendo-se o resultado constante da Tabela 7 .

\section{Agregados de minerais não magnēticos}

Com exceção da magnetita, este grupo de agregados de minerais ocorre apenas em zonas com veios de vermiculita e raramente constituindo vênulas hidrotermais delgadas na ultrabāsica. Não foi encontrado formando eluviões, talvez pelo fato de constituir pequena porcentagem dos opacos co muns no distrito. A granulação é fina, em torno de $1 \mathrm{~mm}$ pá ra baixo, e o grupo ē quantitativamente pouco representativo. os minerais identificados foram os seguintes:cromi 
ANALISE QUIMICA DE AGREGADOS DE MINERAIS DE MAGNETISMO FRACO

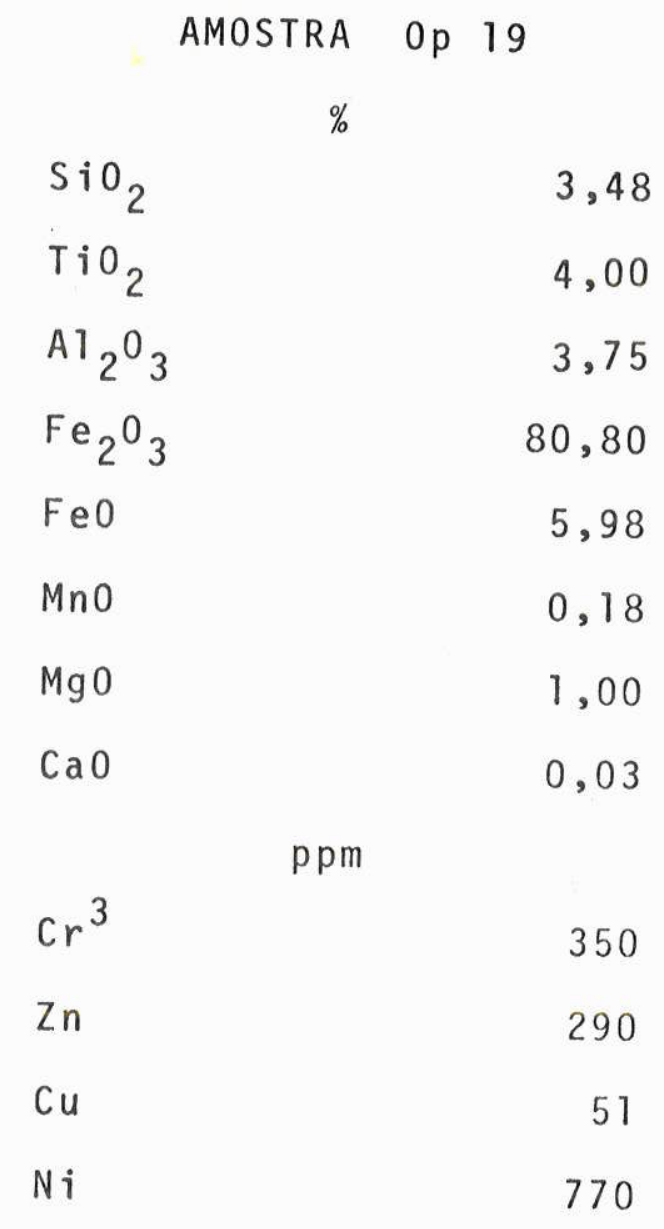




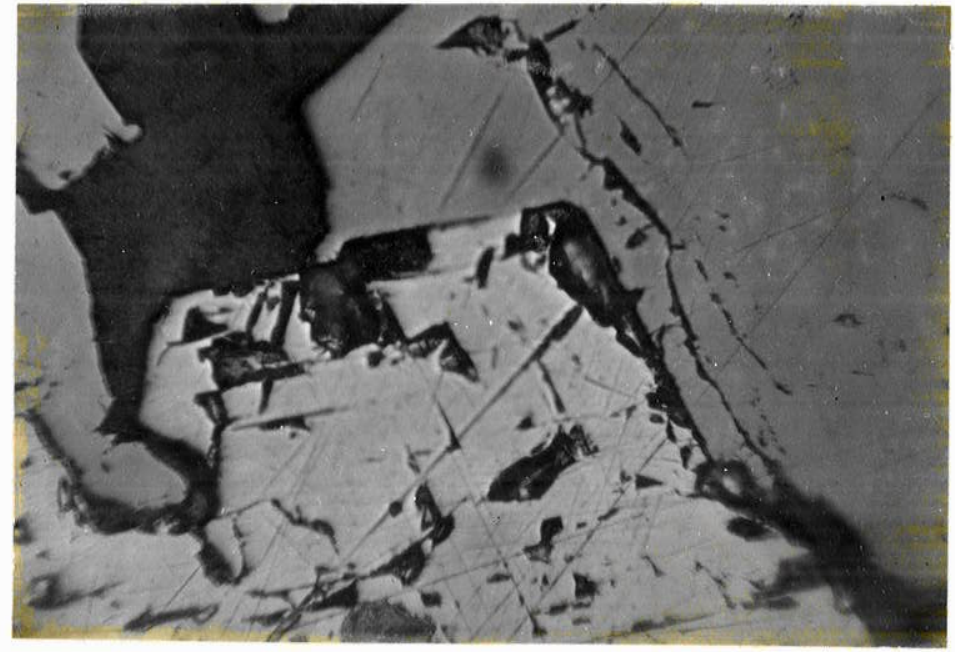

Foto 41 - Galena (cinza mais clara) com marcas triangulares incipientes e riscos de polimento. Ilmenita cinza clara, e ganga, cinza escura. Aumento $320 \mathrm{X}$. 
ta, hematita (produto de martitização), rutilo e goethita.

Descrição dos minerais:

a) Cromita

(Fe, $\mathrm{Mg})(\mathrm{Cr}, \mathrm{Al}, \mathrm{Fe})_{2}{ }^{0} 4^{\circ}$ Pode conter até $12 \%$ de $\mathrm{ZnO}, 8 \%$ de $\mathrm{V}$ e algum $\mathrm{Mn}$, Ti, etc.

Sistema cūbico.

Caracteristicas observadas: Agregados de cristais idiomōrficos homogēneos, às vezes com textura cataclāstica. Cor cinza escura, isōtropo, sem reflexão interna (rica em $\mathrm{Fe}$ ).

A refletividade é média. A amostra foi coletada em vēnulas milimētricas que tomam aspecto arboriforme na UI tramāfica. Veeiros de cromita jā foram descritos por BERBERT \& MELLO em 1967 e BERBERT, MELLO \& CORREA em 1968. Estes au tores descreveram cromita nas localidades de Morro Feio, Mai ripotaba, Interlāndia e Morrinhos.

Nos primeiros anos de pesquisa, a cromita era con siderada anterior aos silicatos, portanto, "magmātica precoce". Estudos posteriores a colocaram tambēm na posição de "magmāticas tardias" e, algumas vezes mesmo, injetadas nas rochas em uma fase final. Assim, a concentração do $\mathrm{Cr}$ pode ser precoce, mas o fim da cristalização da cromita pode ser tardio, podendo constituir disseminações ou delgadas vênulas na fase de migração pneumatolĩtica-hidrotermal.

b) Hematita (produto de martitização)

Idem ao item b) do grupo 2 (Agregados de minerais de magnetismo fraco).

A ūnica observação referente a este mineral e a total martitização da magnetita, sem vestígios reliquiares. 


\section{c) Rutilo}

Idem ao item d) do grupo 2 (Agregados de minerais de magnetismo fraco).

d) Goethita

$\alpha$ - FeOOH (com quantidades variāveis de āgua adsor vida). Sistema ortorrōmbico.

Caracteristicas observadas: Agregado de cristais muito finos, cor cinza clara, anisotropia distinta.Reflexões internas marrom avermelhadas. E um produto de alteração da magnetita e ocorre em zonas de certa porosidade, indicando tambēm sua origem a partir de processos supērgenos. sō foi observada em seções coletadas de rolados superficiais, con firmando sua origem secundāria. Não é um mineral represeñ tativo e ocorre muito raramente no distrito.

\section{CAPITULO X}

SUMĀRIO E CONCLUSÕES

1 - Apōs a intrusão ultramāfica a região foi subme tida a um processo regional de aplainamento, comprovado pelo nivelamento regional ainda existente nos morros testemunhos de dunitos e gnaisses capeados pelo Arenito Furnas na região a $N$ e a $S$ do distrito. A este ciclo seguiram-se fases de formação de crostas de calcedōnea e laterita e, apōs, rejuve nescimento, com erosão e degradação mecãnica dessas crostas.

$$
2 \text { - } 0 \text { maciço de Santa Fé compõem-se de um domo zo }
$$
nado, com núcleo de dunito serpentinizado e circundado por 
camadas descontinuas e concēntricas de peridotitos e piroxe nitos que, por sua vez, são localmente envolvidos por gnais ses cataclasados e hornblenda gnaisses gerados por metamor fismo de contato.

Pequenas intrusões de missouritos e malignitos in trometeram-se no maciço ultramāfico ou estão entremeadas nós contatos do maciço com as encaixantes gnāissicas. Diferenças químicas e físicas observadas no dunito, assim como na tectô nica e morfologia do distrito, levam a admitir mais de uma intrusão, seguida de algumas alcalinas associadas. Estas in trusões posteriores poderiam ser responsāveis pelo fato dos contatos $E$ e $W$ do maciço mergulharem para $W$, sugerindo per turbações tectōnicas pelo menos em uma das bordas da intrusão.

A serpentinização mais intensa em profundidade, e as caracteristicas físicas diferentes indicam que aquele fe nômeno ē ascendente e causador da formação de dois polimor fos predominantes, que são a crisotila e a lizardita. Proces so superficial descendente atuou posteriormente, serpentin zando mais uniformemente as zonas olivínicas ainda preserva das do fenómeno anterior.

Veios de vermiculita, concentrações de opacos e al teração da ultramäfica com formação de talco e carbonatos tềm indicado atividades de soluções hidrotermais em faixas e zo nas irregulares. Nestas foi identificada perowskita, apati ta, magnetita e ilmenita.

A identificação de dunitos, peridotitos e piroxeni tos pela cor e estado de agregação, em certa profundidade e grau de alteração, constituiu um simples e efetivo mētodo de mapeamento de campo das rochas do distrito.

3 - 0 corpo intrusivo é limitado em sua periferia por um sistema de fraturas paralelas aos contatos, de expres 
são superficial visível na região do Tirapressa, ao sul do distrito. Nesta mesma região outro sistema de fraturas e falhas de maior amplitude tem expressão topogrāfica, deli neando os espigões e algumas escarpas daquela ārea. Sua at $\underline{i}$ tude é variāvel e não coincidente com os contatos do maciço, talvez relacionada aos esforços dirigidos de intrusões poste riores. Um terceiro sistema deve se relacionar à serpenti nização e e expressado por um intenso microfraturamento das rochas.

$$
4 \text { - } 0 \text { perfil de alteração representativo das }
$$

āreas baixas e planas estā representado, de cima para baixo, por um nível de solo ferralítico marrom, composto de concre ções ferruginosas ooliticas e pisoliticas imersas em poeira ferruginosa, com espessura mēdia de $4 \mathrm{~m}$. A fração predomi nante das concreções oolīticas distribui-se entre 32 e $11 \overline{5}$ mesh e não varia com a profundidade. 0 nūcleo das concre ções contēm cristais de magnetita, fragmentos da prōpria con creção e, raramente, cromita.

As concreções pisoliticas envolvem com seu cimen to cristais de magnetita, ilmenita e cromita. Contêm disper sos em suas camadas concēntricas elementos tais como $\mathrm{Cr}$, Fe, $\mathrm{Ni}, \mathrm{Ti}, \mathrm{Co}, \mathrm{Al}, \mathrm{Mn}$ e Si. Anālises de microssonda pela "Va riação bidimensional" constituiram uma tēcnica ūtil na iden tificação de minerais opacos englobados nas concreções, assim como no estudo da distribuição dos elementos dispersos nas camadas constituintes das concreções.

Abaixo do solo ferralítico marrom, outro, de com posição quīmica semelhante, concrecionārio, porém mais fino, de cor amarela e espessura mēdia de $0,9 \mathrm{~m}$, contēm teores mais elevados de $\mathrm{Ni}$. Sotoposto a este nivel localiza-se a ultramāfica alterada "in situ", com teor elevado de Ni, mas que decresce com a profundidade. As vênulas de garnieri 
ta, magnesita e vermiculita disseminada fina restringem-se a este terceiro nīvel. A calcedōnea distribui-se neste nível e também no solo ferralítico amarelo.

Nas encostas de morros ou topo de elevações, a ul tramāfica alterada "in situ" aflora sem capeamento laterīti co, localmente com restos de crostas de calcedōna. Vênulas de magnesita, garnierita e calcedōnea estão presentes em to do este perfil, diminuindo em profundidade, em direção à ul tramāfica serpentinizada coesa.

5 - No grupo de minerais de magnetismo forte é co mum a oxidação da magnetita com a formação de maghemita e he matita. Lamelas de ilmenita na magnetita resistem a este processo. Agregados de minerais de magnetismo fraco asso ciam-se às zonas de ocorrēncia de veios de vermiculita; a he matita é formada exclusivamente às expensas da magnetita. 0 rutilo formou-se, preferencialmente, pela alteração da ilme nita. Finalmente, observa-se que os agregados de minerais não magnēticos não formam eluviões e ocorrem apenas em zonas que contêm veios de vermiculita. E um grupo quantitativamen te pouco representativo, em que a goethita forma-se pela al teração da magnetita.

A paragênese mineralōgica dos opacos associa mine rais originais na ultramāfica, principalmente a magnetita e cromita, seguida de minerais formados por ação hidrotermal-metassomātica (ilmenita, rutilo e galena), e, finalmente,mi nerais originados da alteração supērgena dos anteriores, re presentados pela hematita, maghemita, goethita e provavelmen te rutilo.

6 - Em zonas baixas, de topografia plana, a pro fundidade do nível hidrostātico aumenta quando se afasta dos córregos, atingindo, a pouco mais de $200 \mathrm{~m}$ destes, a média 
de 5,2 m. Em āreas planas, distantes mais de $300 \mathrm{~m}$ de cōrre gos, o nível hidrostātico encontra-se entre 5 e $10 \mathrm{~m}$ de pró fundidade, portanto, localizado na ultramāfica alterada, aba $\underline{i}$ xo do solo ferralítico amarelo. Observa-se tambēm que, ao se aproximar dos cōrregos, os "picos" de teores de $\mathrm{Ni}$, nor malmente localizados acima da zona de variação do nível hi drostātico, desaparecem e dão lugar a uma distribuição mais homogênea daquele elemento no sentido vertical, inclusive com um certo enriquecimento abaixo do nīvel hidrostātico atual. Como resultado do processo de alteração e enriqueci mento, os teores de $\mathrm{Ni}$ podem ser considerados como inversá mente proporcionais às densidades do dunito alterado "in situ".

7 - Em perfis verticais, derivados de mais de 2.500 anālises quīmicas de amostras de poços, observa-se o carāter residual acumulativo dos elementos $\mathrm{Fe}, \mathrm{Cr}$ e $\mathrm{Co}$, que se concentram no inīcio do perfil e decrescem com a profun didade.

0 Mg0, por sua vez, è extremamente solūvel, sendo lixiviado intensamente no topo do perfil de solo. Suas por centagens mantēm-se mais elevadas nos dunitos do que nos pé ridotitos e piroxenitos, tanto no topo quanto na base do per fil de solo.

$0 \mathrm{Ni}$ tem um comportamento seletivo, concentrando-se distintamente nos dunitos, especialmente no nível do so 10 ferralítico amarelo e, logo abaixo, no saprōlito fino for mado por alteração da ultramāfica.

8 - A vermiculita constitui veios sem continuida de horizontal ou vertical. Ocorre nos locais de maior con centração de minerais opacos e tem localmente controle estrú tural. 0 modo de ocorrência, assim como as características 
citadas anteriormente, indicam uma origem hidrotermal para este mineral.

9 - A garnierita ocorre na forma disseminada, prẹ enchendo parte dos espaços reticulados de estruturas de "box work" silicosos, ou, então, constituindo vênulas delgadas. As vênulas não são visíveis no solo ferralítico marrom ou amare 10, se bem que neste $\bar{u} 1$ timo os teores de $\mathrm{Ni}$ sejam elevados. Vênulas tīpicas em sua cor, analisadas em raios $x$, mostraram na composição mineralōgica garnierita, hoshiita e serpentina.

10 - Silicificação incipiente ou formação de cros tas de calcedōnea são fenōmenos observados em alguns morros isolados ou em zonas planas de pequena altitude. Horizontes de calcedōnea celular podem se formar na interfācies de dife rentes zonas de alteração, a alguns metros de profundidade. As crostas de calcedōnea são constituídas de quartzo micro cristalino, bandado ou maciço, com zonas recristalizadas de granulação mais grosseira.

CAPITULO XI

AGRADEC IMENTOS

Consigno os meus agradecimentos pela inestimāvel cooperação prestada pelas seguintes pessoas e organizações:

Mineradora Montita Ltda. pela permissão de consul ta dos dados de pesquisa e visitas à ārea pertencente à Com panhia. Dos geōlogos Carlito, Eduardo e do Engenheiro Rikio 
aproveitamos especialmente as discussões francas e acompanha mento nos trabalhos de campo. Neste mister fomos auxiliados tambēm pelo geōlogo Hilton S. Lellis.

Professor Doutor Kenkichi Fujimori, pelos estudos de seções polidas por microssonda eletrōnica.

Professor Doutor José Vicente Valarelli e Paulo E. Mori que providenciaram e interpretaram espectros de difra ção de raios $X$.

Professor Doutor Raphael Hypōlito, pelas anālises quỉmicas por via úmida e absorção atōmica.

Professor Doutor Marcos Berenholc pelas anālises por fluorescência de raios $X$.

Professores Doutor Vicente Antonio Vitörio Girardi, Doutor Marcos Aurélio Farias de 01 iveira e Doutor José Moacyr Vianna Coutinho, pelo acompanhamento constante nos estudos de microscopia de lâminas delgadas.

Professor Gildo Fernando Fuck pelas anālises ter mo-diferenciais.

Professor Doutor Evaristo Ribeiro Filho, pelas mi crofotografias de seções polidas.

Aos Professores Doutor José Vicente Valarelli, Dou tor Reinholt Ellert e Doutor Vicente A.V.Girardi, e o pōs-dou torando Everaldo Zeferino de Mello pelas revisões do texto, e inūmeras e valiosas sugestões.

Ao Sr. Josē Ponchirolli, Sra. Nair de Campos Louza da e Sra. Aparecida Nunes Comi, pelo esmero na redação prelimi nar e final da tese. 
A Srta. Itacy Kroehne e Srta. Nami Koseki pelos cuidadosos serviços de desenho.

Ao Sr. Jaime de Souza Marcos que encarregou-se das ilustrações e reproduções fotogräficas.

A Sra. Melany Thereza Isauk, Sr. Clāudio Hopp e Sra. Almerinda Palmeira pela preparação cuidadosa de lâminas delgadas das rochas do distrito.

Finalmente os agradecimentos são extensivos à equi pe que sob orientação do Sr. Jaime Alves da Silva, tornaram viāvel a impressão da tese.

A numerosos outros colegas externamos nossos agra decimentos pela sōlicita e desinteressada cooperação. Pelö estīmulo constante lembramos o nome do Professor Doutor Viktor Leinz.

CAPITULO XII

BIBLIOGRAFIA

ANGEIRAS,A.G. (1968) A Faixa de serpentinitos da região central de Goiás; Anais da Acad.Bras.de Cien; Vol. 40, Suplemento, Rio de Janeiro.

BARNES,I \& \& O'NEIL,J.R. (1969) The relationship between fluids and some fresh alpine-type ultramafics and possible modern serpentinization, Western United Sta tes; Bull.Geol.Soc.Am., V.80, pp.1947-1960. 
BASTA,E.Z. (1959a) Some mineralogical relationships in the system $\mathrm{Fe}_{2} \mathrm{O}_{3}-\mathrm{Fe}_{3} \mathrm{O}_{4}$ and composition of titanomaghemite; Econ.Geol.; V.54, pp.698-719.

BASTA,E.Z. (1959b) New data on the system $\mathrm{Fe}_{2} \mathrm{O}_{3}-\mathrm{FeTiO}_{3}-\mathrm{TiO}$ (Ferrilimenites and Titano-maghemites); Egypt. Acad. Sci.Proced. XIV.

BERBERT,C.0. (1970) Geologia dos complexos bāsicos ultrabās i cos de Goiās; Anais do XXIV Congr.Bras.de Geol., Brä siria; pp.41-50.

BERBERT,C.0.; MELLO,J.C.R.de (1967) Cromita no Morro Feio, Hidrolândia, Goiās; Anais do XXI Congr.Bras.de Geol., pp. 108-112.

BERBERT,C.0.; MELLO,J.C.R.de \& CORREA,J.A. (1968) - ocorrēncias Minerais de Interēsse Econômico na Ärea de Interlāndia-Abadiânia, Goiās; Comunicação ao XXII Con gr.Bras.de Geol., Belo Horizonte,MG.

BETKHTIN,A.; A Course of Mineralogy; Peace Publishers, Moscou, p. 544 .

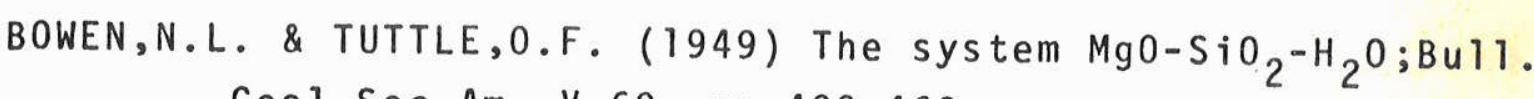
Geol.Soc.Am., V.60, pp.439-460.

COMBES,P.J. (1963) A propos du nickel dans les laterites nickelifëres de la Nouvelle Caledonie; Compt. Rend. Acad. Sci. 256, pp.211-212.

DEER,W.A.; HOWIE,R.A. \& ZUSSMAN (1962) Rock-Forming Minerals; V.5, 3, John Wiley and Sons Inc. N.Y.

EDWARDS,A.B. (1965) Texture of the ore minerals; Austral. Instit. of Min.and Metal., Melbourne.

FAUST,G.T.; MURATA,J. \& FAHEY,J.J. (1956) Relation of minor-element content of serpentines and their geological origin; Geoch.et Cosmoch. Acta, V.10, pp. 316320. 
FAUST,G.T. \& FAHEY,J.J. (1962) The serpentine group minerals; Prof.Pap; U.S.Geol.Surv; 384A, pp. 1-92.

FAUST,G.T. (1966) The hydrous nickel-magnesium silicates. The garnierite group; Am.Mineralogist; V.51, pp. 279-298.

FAUST,G.T. \& NAGY,B. (1967) Solution studies of chrysotile, lizardite and antigorite; Geol.Surv.Prof. Paper; 348-A.

FIGUEIREDO,A.N.; MOTTA,J. \& MARQUES,V.J. (1975) - Estudo com parativo entre os complexos de Barro Alto e do Tocantins, Goiàs; Rev.Bras.de Geociências; V.1, março de 1975, pp.15-29.

GALVAO,M.V. (1960) Geografia do Brasil; Grande Região Centro 0este, V.II; Sērie A, IBGE, Cons.Nac.de Geog., pp. 9-117.

GUIMARAES, G.; GLASER, I. \& MARQUES,V.J. (1968) Sobre a ocorrência de Rochas Alcalinas na Região de Iporā, Goiās; Min.e Metal., V.XLVIII (283), pp.11-15 - Rio de Janeiro.

HEIER,K. (1956) Thermometric and petrogenetic significance of titaniferous magnetite - Discussion; Am.Jour. Scie; V.254, pp.506-515.

HUANG,W.T. (1962) Petrology; Baylor University.

HYNDMAN,D.W. (1972) Petrology of igneous and metamorphic rocks; McGraw Hill.

KABESH,M.L.; AFIA,M.S. \& WIDATALLA,A.L. (1958) Fodiwan iron deposits; Geol.Surv.Dept. Rep.Sudam, Bull.4 (In Deer, W.A. et a 1. 1962).

KLOCKMAN,F. \& RAMDOHR,P. (1955) Tratado de Mineralogia; 2a ed. Editora Gustavo Gili S.A., Barcelona, p.436.

LINDENMAYER,D.H. \& LINDENMAYER,Z.G. (1971) Intrusões U1trabāsicas-alcalinas e suas mineralizações a niquel - In: XXV Congr.Bras.Geo1.;Soc.Bras.de Geo1.,Bo1.Esp.no 1 (Resumo), São Paulo. 
MIDGLEY,H.G. (1951) Chalcedony and flint; Geol.Magazine;V.88, p. 179 .

NOBLE,J.A. \& TAYLOR JR.,H.P. (1960) Correlation of the ultramafic complexes of southeastern Alaska with those of other parts of North America and the world; $21 \mathrm{st}$ Intern.Geol.Congr., Copenhagen, Repts. V.13, pp.188-197.

PENA,G.S. \& FIGUEIRED0,A.J.A. (1972) Projeto Alcalinas;DNPM/ /CPRM, Relatōrio Inēdito, Goiānia.

RAMDOHR,P. (1969) The ore minerals and their intergrowth;Pergamon Press, 3rd edition.

RUCKMICK,J.C. \& NOBLE,J.A. (1959) Origin of the ultramafic complex at Union Bay, southeastern Alaska;Bull.Geol. Soc.Am; V.70,pp.981-1018.

SCARFE,C.M. \& WYLLIE,P.J. (1967) Serpentine dehydration curves and their bearing on serpentine deformation in orogenesis; Nature, Lond; V.215, pp.945-946.

SCHOBBENHAUS FILHO,C.; RIBEIRO,C.L.; OLIVA,L.A; TAKANO HASHI, J.T.; LINDENMAYER,Z.G.; VASCONCELOS,J.B.; ORLANDI, V. (1975) Carta Geolōgica do Brasil ao Milionésimo; FoTha Goiàs (SD 22), DNPM,DGG, Brasīita.

SEMENOV,E.I. Economic Mineralogy of Alkaline Rocks (In:Sorensen,H.(1974), John Wiley \& Sons, p.544).

SORENSEN,H. (1974) The Alkaline Rocks; John Wiley \& Sons.

SOBRINHO,M.L. \& ANDRADE,R.S. (1971) Geologia da Quadrícula de Britānia, Santa Fē, Araguapaz e Jussara;Projeto Jussara; Comp.de Pesq.de Rec.Min.

SOBRINHO,M.L.; ANDRADE,R.S. \& MARQUES,V.J. (1971) Missouritos e rochas alcalinas associadas em Santa Fé, Municipio de Jussara,G0; Bol. Especial nol, Resumo das Comunica ções; XXV Congr.Bras.de Geol., São Paulo.

SOSMAN,R.B. (1927) The properties of silica; New York. 
SPANGENBERG,K. (1938) Die wasserhaltigen Nickelsilicate; Cent. Mineral. Abt. A, pp.360-364.

TAYLOR JR.,H.P. \& NOBLE,J.A. (1960) Origin of the ultramafic complexes in southeastern Alaska; 21 st Intern. Geol. Congr; Copenhagen, Repts. V.13, pp.175-187.

TERNOVOY,V.I.; AFANASIEV,B.V. \& SULIMOV,B.I. (1969) Geology and Prospecting of the Kovdor Vermiculite-Phlogopite Deposit (Em Russo) Izd. "Nedra", Moskva, 287 pp. (In: Sorensen, H. 1974).

UYTENBOGAARDT, W. (1951) Tables for microscopic identification of ore minerals; Princeton University Press.

ZEISSINK,H.E. (1969) The mineralogy and geochemistry of a ni ckeliferous laterite profile; Mineralium Deposita, V.4; no2, pp.134-135.

ZIV,F. (1956) Rutilization of ilmenite under supergene condi tions; Izvest. Akad. Nauk; SSSR, Ser.Geol. no 12,p. 57. 


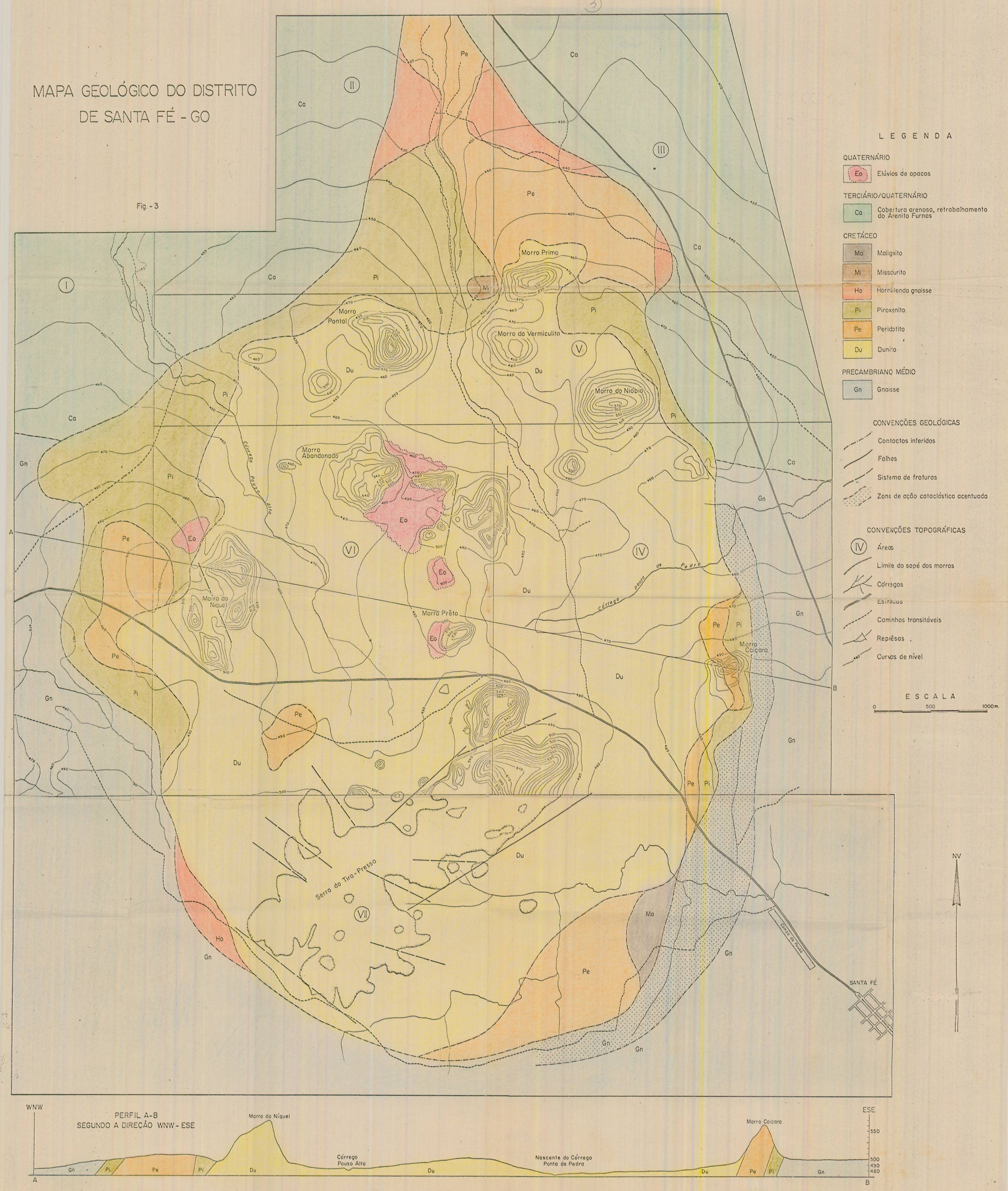




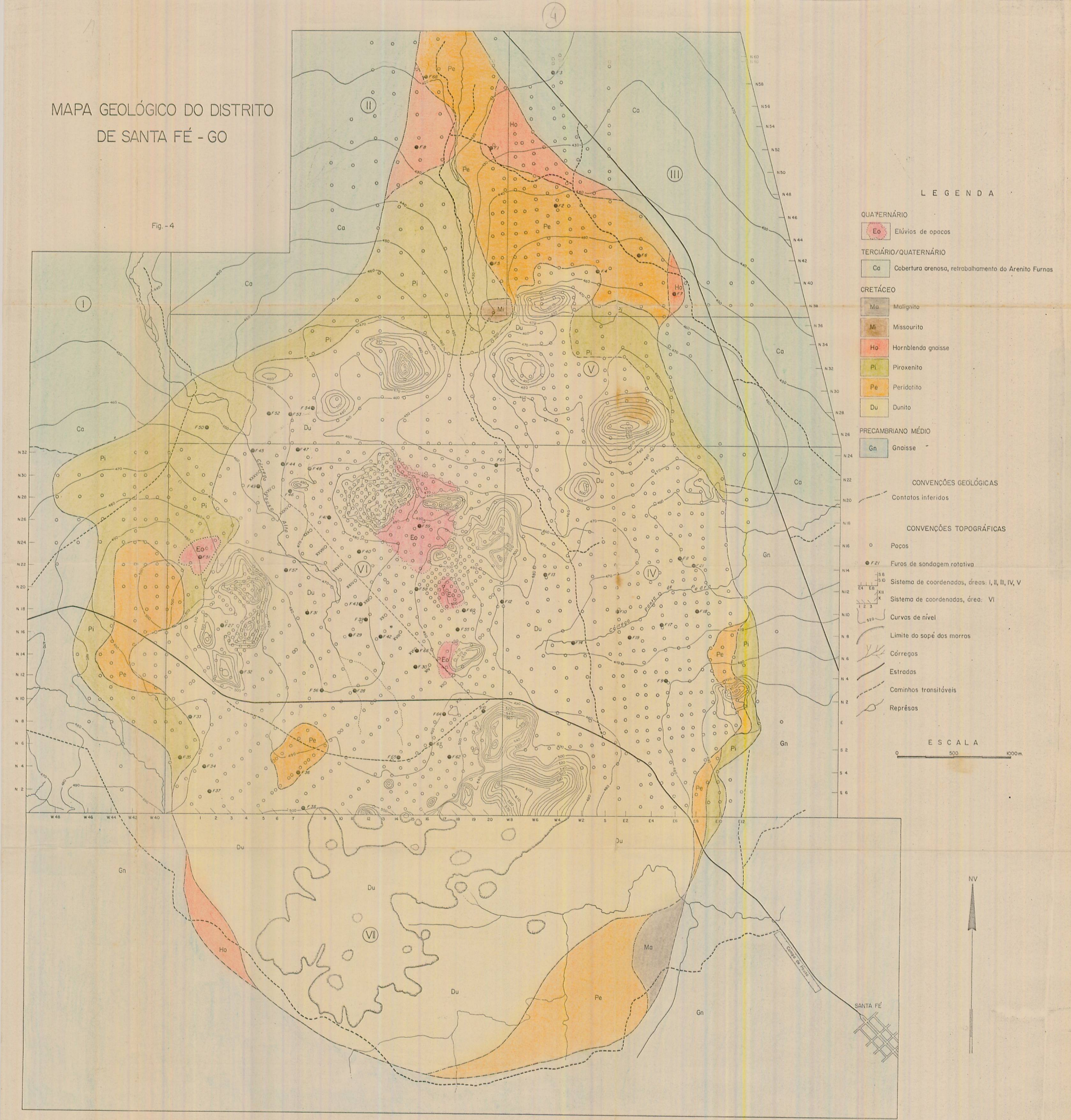

